\title{
Carcinization in the Anomura - fact or fiction? I. Evidence from adult morphology
}

\author{
Patsy A. McLaughlin ${ }^{1}$ \& Rafael Lemaitre ${ }^{2}$ \\ ${ }^{1}$ Shannon Point Marine Center, Western Washington University, Anacortes, Washington, U.S.A.; ${ }^{2}$ Depart- \\ ment of Invertebrate Zoology, National Museum of Natural History, Smithsonian Institution, Washington, \\ D.C., U.S.A.
}

Keywords: Carcinization, Anomura, Paguroidea, Galatheoidea, Hippoidea, Lomoidea, Paguridae, Lithodidae, adult morphology, phylogeny

\begin{abstract}
Carcinization, or the process of becoming a crab, has been, and continues to be, a focal point of anomuran evolutionary hypotheses. Traditional examples of carcinization in the Anomura are most celebrated among hermit crabs but certainly are not limited to this group. Carcinization, if it has occurred, has done so independently in all major anomuran taxa.

In this critique, the traditional examples of carcinization in the Anomura are reviewed and more modem variations on the theme assessed. Potential pathways of carcinization are examined from perspectives of adult morphology in the Paguroidea, Galatheoidea, Hippoidea and Lomoidea, with emphasis on the Paguroidea. Specific attention is given to the theoretical transformation of a hermit crab-like body form into a "king crab"like lithodid crab. Resulting coercive evidence indicates: (1) that while the evolution of a crab-like body form certainly occurs, the traditional applications, based on inadequate and often inaccurate data, are flawed; and (2) that lithodid crabs did not arise from a hermit crab predecessor through the process of carcinization.
\end{abstract}

\section{Résumé}

La carcinisation (processus par lequel on devient un crabe) a été, et continue d'être, un point focal des hypothèses sur l'évolution des Anomures. Les exemples les plus connus de carcinisation chez les Anomures sont fournis par les Pagures, mais le phénomène n'est certainement pas limité à ce groupe. S'il y a eu carcinisation, celle-ci s'est indépendamment produite dans tous les grands groupes d'Anomures.

Dans le présent aperçu critique on passe en revue les exemples traditionnels de carcinisation dans ce groupe et on évalue les variations plus récentes sur ce thème. Dans la perspective de la morphologie des adultes on examine les voies potentielles de la carcinisation chez les Paguroidea, Galatheoidea, Hippoidea et Lomoidea, en insistant sur les Paguroidea. Une attention spéciale est accordée à la transformation - en théorie - d'un habitus du type Pagure dans celui d'un crabe lithodide. L'évidence qui s'impose indique: (1) qu'une évolution vers un habitus de crabe existe certainement, mais que les interprétations traditionnelles de ce phẻnomène, basées sur des données inadéquates et souvent dépourvues de précision, sont erronées; (2) que les crabes lithodides n'ont pas évolué par carcínisation à partir d'un ancêtre Pagure.

\section{Introduction}

A number of decapods look like crabs, but do not qualify as "true" crabs (Brachyura) because of adult morphological inconsistencies or larval characteristics. Presumably, to become a "true crab" requires that a reptant decapod undergo carcinization (Borradaile, 1916) or brachyurization (ŠtevÇi $\varnothing, 1971)$. Although the two terms appear here to be synonymous, we believe that not all authors who have employed "carcinization" or "brachyurization" have had quite the same phenomenon in mind. For example, Martin \& Abele (1986) defined carcinization as the reduction and folding of the abdomen beneath the thorax, whereas Sluys (1992) used carcinization to mean the evolution of a crab-like appearance as in lithodids. To Blackstone (1989) hermit crabs became carcinized through broadening of the carapace and reducing the habitation of shells. In this first article, we address anomuran carcinization only from the perspective of adult morphology.

We accept that the Anomura, as defined by McLaughlin (1983b) and McLaughlin \& Holthuis (1985), include four major taxa: Galatheoidea, Hippoidea, Lomoidea, and Paguroidea. We recognize Forest's (1987) elevation of the Paguroi- 
dea to Section Paguridea with superfamilies Paguroidea and Coenobitoidea; however, hierarchical ranking has no bearing upon our discussion. We are aware of the propositions made recently by Williamson (1992) and by Spears et al. (1993), but disputed by Scholtz \& Richter (1995), that the Dromioidea are actually anomurans. Similarly, we note, but do not concur with, the reintroduction of "Anomala" by the latter authors.

Borradaile (1916), who first proposed the term carcinization, implied a quite specific meaning, i.e., "... one of the many attempts of Nature to evolve a crab", and used for his example of carcinization the hermit crab Porcellanopagurus sp.; StevÇiø (1971), on the other hand, proposed the term brachyurization as a "more general term relevant to all crabs as a whole, without regard to shape and organizational level". Wolff (1961b), Guinot (1979), and Türkay (1986) appear to have used carcinization, as Williamson (1992) and Martin \& Abele (1988) have used brachyurization, in the sense of independent, convergent, evolutionary phenomena leading to a crab-like body form. In this review we use carcinization in the sense of Wolff (1961b), Guinot (1979), and Türkay (1986). The only decapods that have demonstrated these apparently evolutionary tendencies of carcinization are members of the Anomura and Brachyura. Presumably, in the Paguroidea carcinization would ultimately lead to the evolution of the lithodid body form, and in the Galatheoidea, to the evolution of the porcellanid body form. The Hippoidea and Lomoidea would appear to have already reached a certain level of carcinization but with no distinct pathways evident. Our intent here is not to discuss anomuran phylogenetic relationships in great depth, but rather to investigate the evolutionary pathways that supposedly have given rise to the crab-like body forms of anomuran taxa, with particular emphasis on the Paguroidea.

As previously indicated, the term carcinization was introduced by Borradaile (1916) to describe the phenomenon he perceived to be the transformation of a typical shell-dwelling hermit crab into a crab-like animal no longer dependent upon a spiraled gastropod shell for protection of its membranous abdomen. However, the phylogeny of the crab-like lithodids had been explored in detail earlier both by Boas $(1880 \mathrm{a}, \mathrm{b})$ and Bouvier (1894a-c; 1895a, b; 1897). Additional examples of presumed paguroid carcinization were reported by Bouvier (1896) and Borradaile (1916) in Ostraconotus A. Milne Edwards, 1880, and Tylaspis Henderson, 1885; in Probeebei Boone, 1926b and Labidochirus Benedict, 1892 by Wolff (1961b) and Blackstone (1989); in Solitariopagurus Türkay, 1986, by Türkay (1986); and in Pagurus hirsutiusculus (Dana, 1851) by Blackstone (1989). As envisioned by most carcinologists, the evolutionary processes involved the modification of an anomuran having an inflated, elongate cephalothorax into one that was broadened and somewhat flattened. Similarly, the long, frequently articulated, and relatively weakly calcified abdomen was converted into one that was not only reduced, but also bent under the thorax and ultimately pressed closely against the sternum. Such transformations required modifications not only to the thorax and abdomen themselves, but also to the entire animal. Morphological diversity within the major anomuran taxa precludes any sweeping generalizations. Among these taxa, carcinization would appear to have been an independent phenomenon that proceeded at varying rates.

\section{Historical review of reported instances of carcinization}

\section{Paguroidea}

The most well-known of these theories are those of Boas (1880a, b, 1924), Bouvier (1894a, c, 1895b, 1897), Cunningham et al. (1992), and Richter \& Scholtz (1994) who perceived evolution of Lithodes Latreille, 1806 (including Paralithodes Brandt, 1848) from a species of Pagurus Fabricius, 1775 (Fig. 1), or another related genus. Although earlier authors (e.g., H. Milne Edwards, 1837; H. Milne Edwards \& Lucas, 1841; Brandt, $1848,1850,1851$ ) had proposed a relationship between Lithodes and Pagurus, Boas (1880a, b) was the first one who attempted to provide morphological data to substantiate such a relationship. These included similarities in the structure 


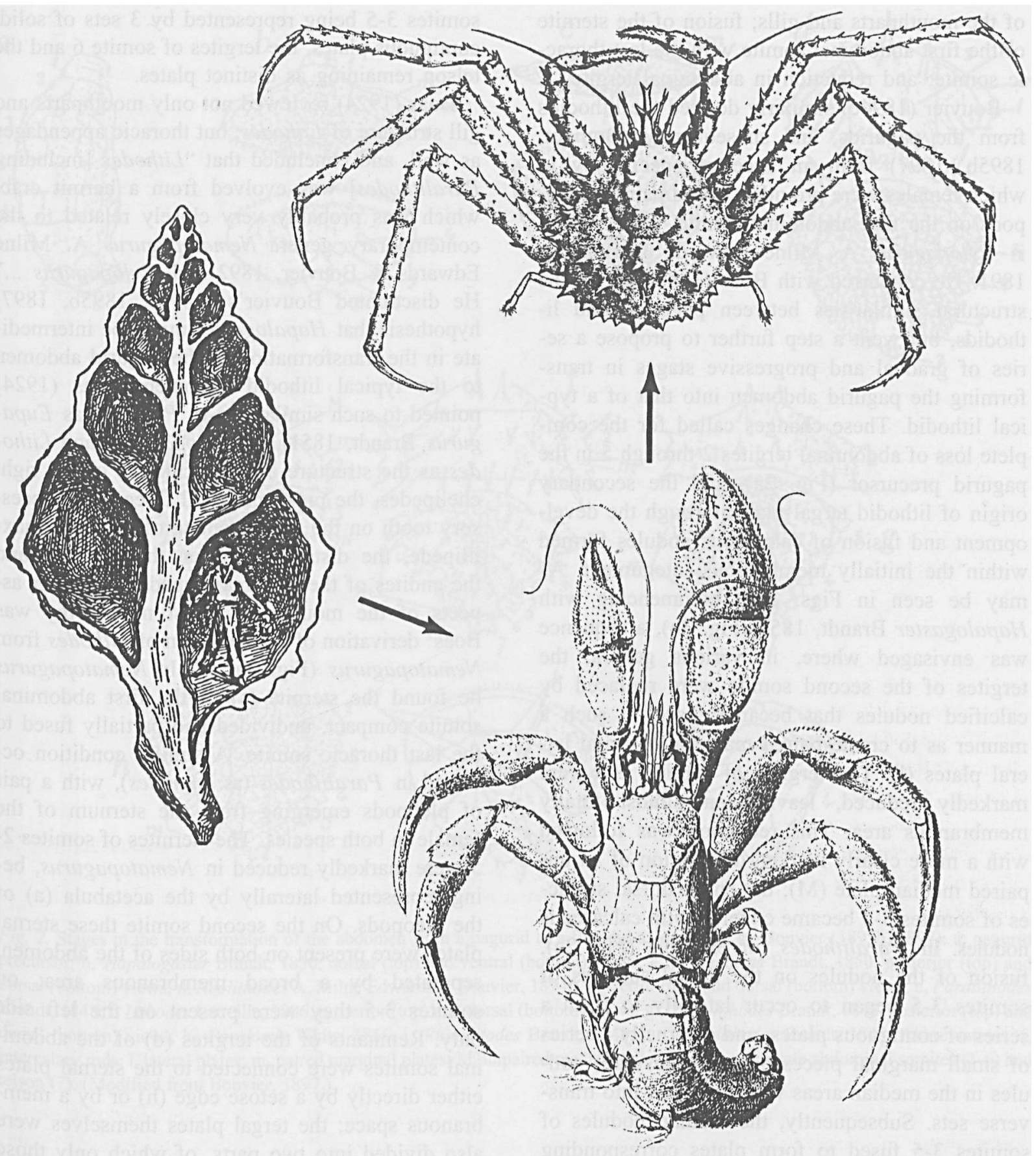

Fig. 1. Hypothetical transformation of Pagurus Fabricius, 1775 to Lithodes Latreille, 1806. To explain the asymmetry of hermit crabs, Pérez (1934) used a fictitious example of a person holding a package while descending on a dextrally coiled stairwell similar to a snail shell (left). The person would find it more comfortable to carry the package on the left hand because there is more space on that side. The implication is that use of dextral shells by hermit crabs led to an abdominal asymmetry favoring the left side. Typical shelldwelling hermit crabs such as Pagurus aleuticus (Benedict, 1892) (bottom, after Benedict, 1901), presumably underwent transformation to crab-like animals no longer dependent on gastropod shells such as Lithodes murrayi Henderson, 1888 (top, after Henderson, 1888). Not to scale. 
of the mouthparts and gills; fusion of the sternite of the first abdominal somite with the last thoracic somite; and reduction in abdominal tergites.

Bouvier (1894c) similarly derived the lithodids from the pagurids, and subsequently (Bouvier, $1895 \mathrm{~b}, 1897$ ) from an ancestor specifically in which females were provided with a pair of gonopods on the first abdominal somite, such as seen n Pylopagurus A. Milne Edwards \& Bouvier, 1891. He concurred with Boas $(1880 \mathrm{a}, \mathrm{b})$ on the structural similarities between pagurids and lithodids, but went a step further to propose a series of gradual and progressive stages in transforming the pagurid abdomen into that of a typical lithodid. These changes called for the complete loss of abdominal tergites 2 through 5 in the pagurid precursor (Fig. 2a), and the secondary origin of lithodid tergal plates through the development and fusion of calcareous nodules formed within the initially membranous integument. As may be seen in Figs. $2 b-j$, commencing with Hapalogaster Brandt, 1850 (Fig. 2b), a sequence was envisaged where, in various genera, the tergites of the second somite were replaced by calcified nodules that became fused in such a manner as to create paired marginal (m) and lateral plates (I). The tergites of somites 3-5 were markedly reduced, leaving an almost totally membranous area. This reduction was followed with a more clearly marked delineation of an unpaired median plate $(M)$; the entire dorsal surfaces of somites 3-5 became covered with calcareous nodules. In Paralithodes for example (Fig. 2e), fusion of the nodules on the dorsal surfaces of somites 3-5 began to occur laterally to form a series of contiguous plates, and externally a series of small marginal pieces began to develop; nodules in the median areas were arranged into transverse sets. Subsequently, the median nodules of somites 3-5 fused to form plates corresponding to, but separated from, the lateral plates by a free, or partially fused, nodular strip. Finally, fusion of all marginal pieces to their respective lateral plates began, along with the formation of intercalary rods (i) between the lateral and median plates by the fusion of the free and partially free nodules. Complete plate fusion, such as seen in Cryptolithodes Brandt, 1848 (Fig. 2j) resulted in somites 3-5 being represented by 3 sets of solid, contiguous plates, the tergites of somite 6 and the telson remaining as distinct plates.

Boas (1924) reviewed not only mouthparts and gill structure of Lithodes, but thoracic appendages as well, and concluded that "Lithodes [including Paralithodes] was evolved from a hermit crab, which was probably very closely related to the contemporary genera Nematopagurus A. Milne Edwards \& Bouvier, 1892 and Pylopagurus ..." He discounted Bouvier's (1894c, 1895b, 1897) hypothesis that Hapalogaster might be intermediate in the transformation of the pagurid abdomen to the typical lithodid abdomen. Boas (1924) pointed to such similarities in Pagurus (as Eupagurus Brandt, 1851), Nematopagurus and Lithodes as the structure and musculature of the right chelipedes, the presence in all three of an accessory tooth on the crista dentata of the third maxillipede, the distance between the endopod and the endites of the first maxillipede, and other aspects of the mouthparts. Most noteworthy was Boas' derivation of the abdomen of Lithodes from Nematopagurus (Fig. 3a, b). In Nematopagurus he found the sternite (s) of the first abdominal somite compact, undivided and partially fused to the last thoracic somite. A similar condition occurred in Paralithodes (as Lithodes), with a pair of pleopods emerging from the sternum of the female in both species. The sternites of somites 25 were markedly reduced in Nematopagurus, being represented laterally by the acetabula (a) of the pleopods. On the second somite these sternal plates were present on both sides of the abdomen, separated by a broad membranous area; on somites 3-5 they were present on the left side only. Remnants of the tergites (d) of the abdominal somites were connected to the sternal plates either directly by a setose edge (h) or by a membranous space; the tergal plates themselves were also divided into two parts, of which only those of the first and second somites adhered closely. The tergal plates on the third to fifth somites were separated by membranous areas. Boas found that the second somite in Paralithodes differed in having a large transverse plate composed of five pieces. He interpreted the central portion of this plate as the median membranous part of the Nematopagurus second somite; the adjacent 

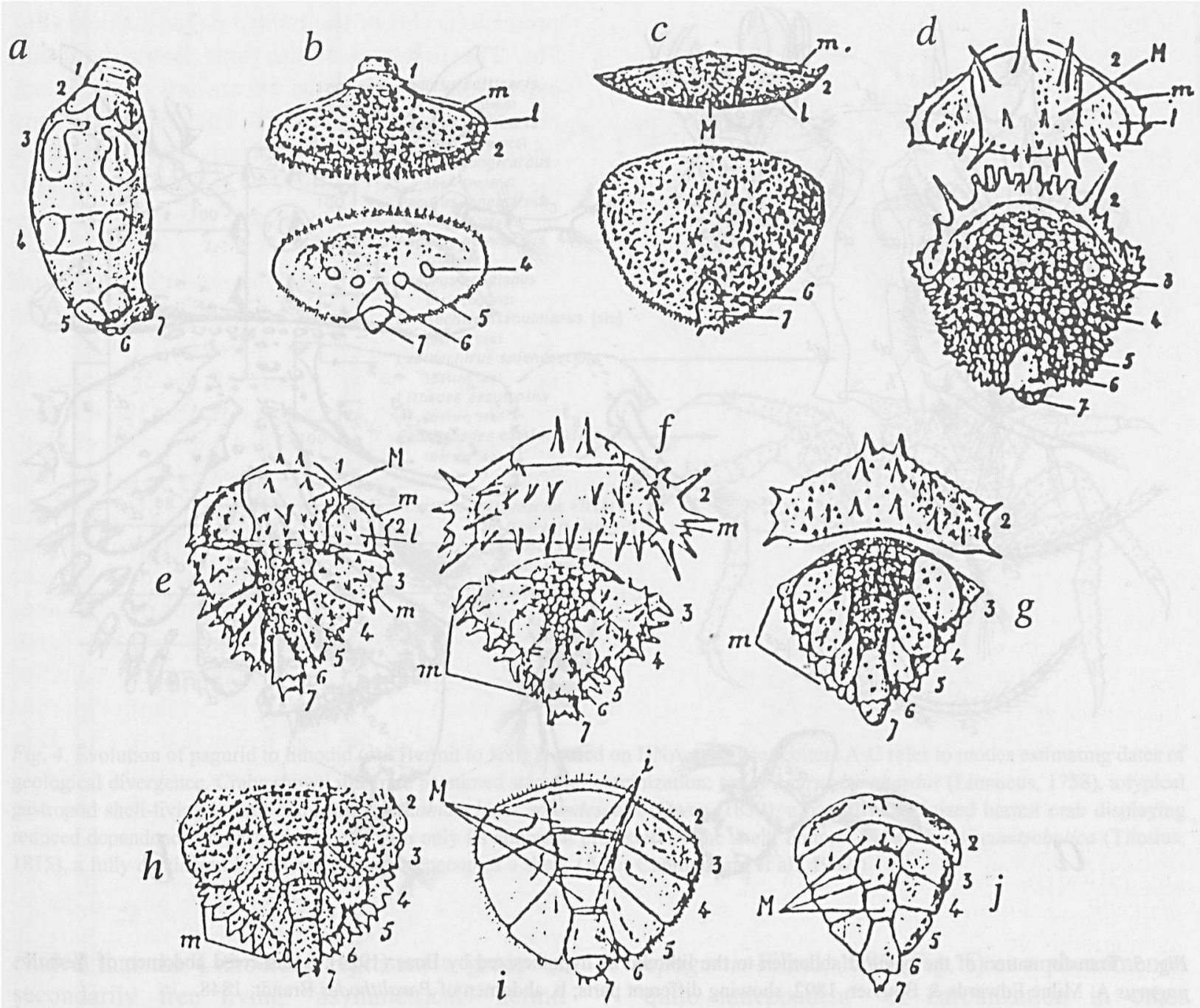

Fig. 2. Stages in the transformation of the abdomen from a pagurid to a lithodid as proposed by Bouvier (1895b, 1897): a, pagurid precursor; b, Hapalogaster Brandt, 1850, dorsal (top) and ventral (bottom) views; c, Dermaturus Brandt, 1850, posterior (top) and dorsal (bottom) views; d, Neolithodes A. Milne Edwards \& Bouvier, 1894b, posterior (top) and dorsal (bottom) views; e, Paralithodes Brandt, 1848; f, Lithodes Latreille, 1806, posterior (top) and dorsal (bottom) views; g, Lopholithodes Brandt, 1848, posterior (top) and dorsal (bottom) views; h, Paralomis White, 1856; i, Rhinolitodes Brandt, 1848; j, Cryptolithodes Brandt, 1848. Abbreviations: i, intercalary rods; 1 , lateral plates; $m$, paired marginal plates; $M$, unpaired median plates. Numbers indicate abdominal somites (1-6) and telson (7). (Modified from Bouvier, 1897.)

plates were homologous with the tergal plates of the pagurid. In Nematopagurus, and Pagurus, the tergal plates are joined to the sternal plates of the somites by membranous strips, and Boas concluded that it was from these that the small marginal plates seen in Paralithodes had developed. Boas reasoned that the loss of uropods in lithodids was a direct result of loss of function; and that elon- gation of the fourth pereiopods reflected a return to typical decapod structure. Before concluding his study, Boas had the opportunity to examine specimens of Pylopagurus, a genus with gonopod bearing females, but one in which the males, like male lithodids, were not equipped with sexual tubes. His conclusion therefore became one in which he evolved Lithodes from an ancestor 


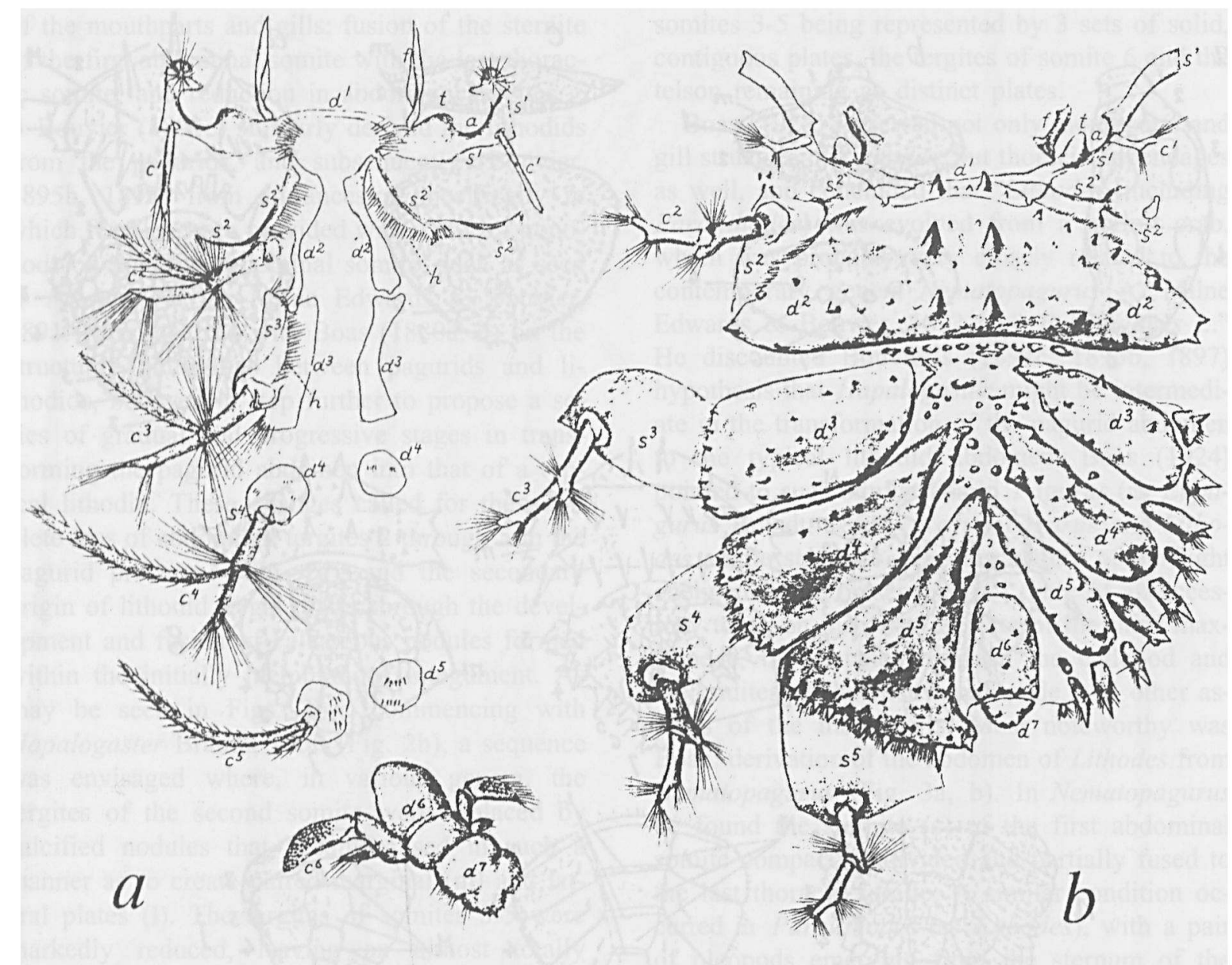

Fig. 3. Transformation of the pagurid abdomen to the lithodid as hypothesized by Boas (1924): a, dissected abdomen of Nematopagurus A. Milne Edwards \& Bouvier, 1892, showing different parts; b, abdomen of Paralithodes Brandt, 1848.

Abbreviations: a, acetabula; $d$, tergite; f, first pleopod; h, setose edge ("Haargebräme"); s, sternite. Numbers denote abdominal somites and telson (modified from Boas, 1924).

closely related to Nematopagurus and Pylopagurus.

More recently, Paralithodes was not only derived from Pagurus (Fig. 4) but the proposition was made by Cunningham et al. (1992) that $P$. camtschatica (Tilesius, 1815) and Lithodes aequispina Benedict, 1895 were more closely related to Pagurus bernhardus (Linnaeus, 1758) and Pagurus acadianus (Benedict, 1901) than were the latter two species to Pagurus pollicaris Say, 1817 and $P$. longicarpus Say, 1817. These authors went so far as to propose that the results from their ribosomal RNA studies justified the inclusion of these two lithodid species in the genus
Pagurus. There is no doubt that a genetic relationship exists between pagurids and lithodids. However, the study by Cunningham et al. (1992) was based on data derived from only eight species from a gene pool in excess of 900 species. In view of the number of morphologically, and seemingly phylogenetically, more closely related intermediate taxa within the Paguroidea, the approach of Cunningham et al. is in need of an expanded data base.

The latest proposal for derivation of the Lithodidae from the Paguridae is that of Richter \& Scholtz (1994). While not suggesting any direct line(s) of descent, these authors similarly con- 


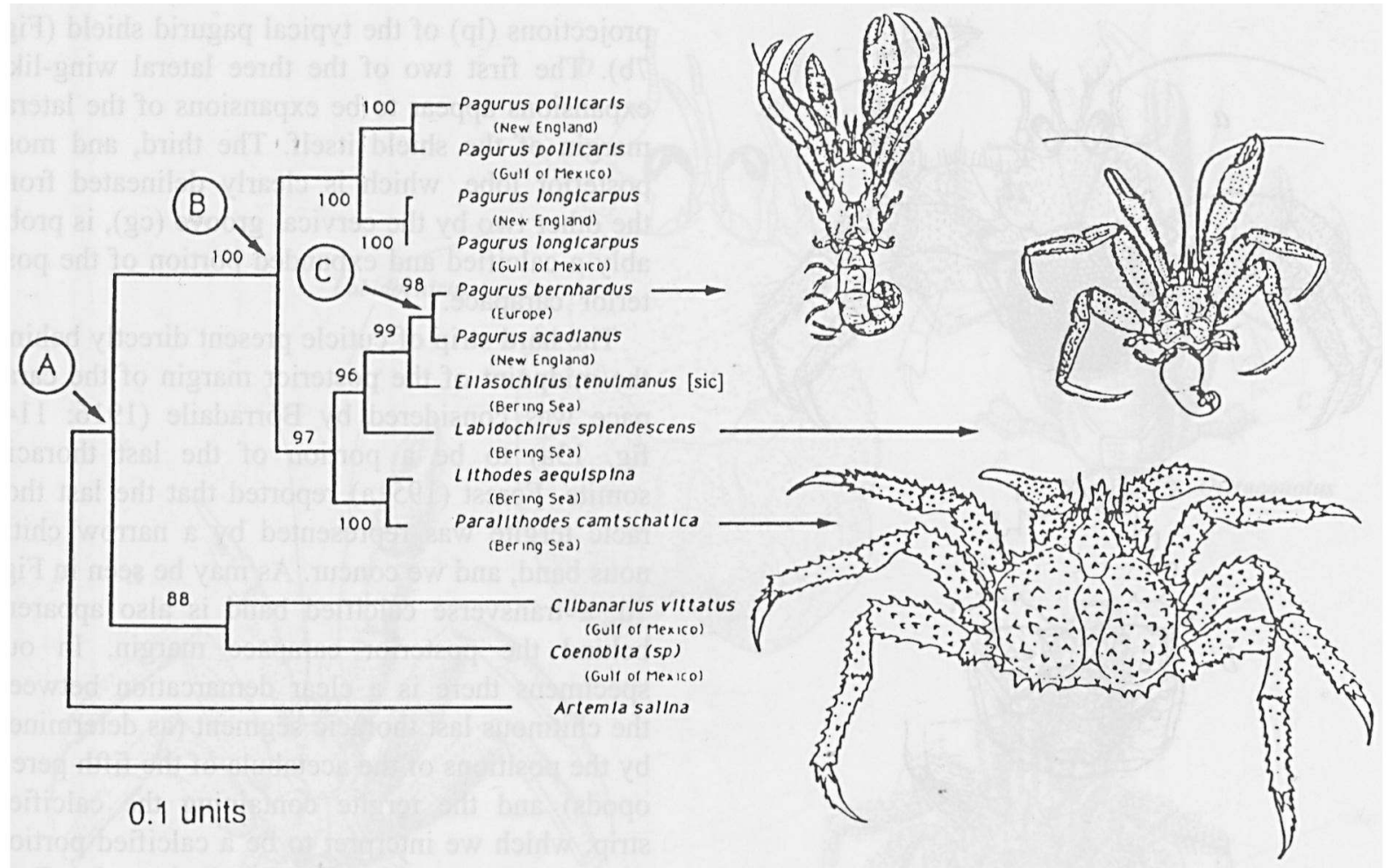

Fig. 4. Evolution of pagurid to lithodid (or "Hermit to King") based on DNA evidence. Letters A-C refer to modes estimating dates of geological divergence. Crabs shown illustrate presumed stages of carcinization: top, Pagurus bernhardus (Linnaeus, 1758), a typical gastropod shell-living hermit crab; middle, Labidochirus splendescens (Owen, 1839), a partially carcinized hermit crab displaying reduced dependence on gastropod shells with only its abdomen protected by the shell; bottom, Paralithodes camtschatica (Tilesius, 1815), a fully carcinized King Crab that never occupies a shell. (After Cunningham et al., 1992.)

cluded that the Lithodidae represent a group of secondarily free living "asymmetrical" hermit crabs. In their study, they presented a series of eight characters that separated their "probably" paraphyletic "symmetrical" Pylochelidae from the monophyletic "asymmetrical" hermit crabs, which included Diogenidae + Coenobitidae, Parapaguridae, and Paguridae-Lithodidae. Their study addressed the issue of carcinization only in their conclusion that the lithodid characters they considered reflected a change toward a free living habit.

Within the Paguridae, several other instances of carcinization have been reported. Whereas Bouvier (1894c, 1895b, 1897) and Boas (1880a, $b, 1924)$ placed primary emphasis on changes in the abdomen and pleopods, Borradaile (1916) emphasized changes in the cephalothorax. He described carcinization in a species of Porcella- nopagurus Filhol, 1885 (Fig. 5) as a phenomenon "quite independent" of carcinization in other anomurans. Borradaile interpreted the widening of the sternite of the third maxillipedes seen in the Paguridae and Parapaguridae as the first step in the carcinization process. Further advances included broadening of the cephalothorax and accompanying calcification, as depicted by Labidochirus splendescens (Owen, 1839) (Fig. 6a, b), Ostraconotus (Fig. 6c), Tylaspis (Fig. 6d), Porcellanopagurus (Fig. 6e), and the semi-terrestrial coconut crab, Birgus latro (Linnaeus, 1767) (Fig. 6f). To emphasize his argument for independent pathways of carcinization in these taxa, Borradaile (1916) noted a number of dissimilarities among them, e.g., male gonopod development, chelipede and pereiopod structure, development of a rostrum, etc.; he gave only passing attention to the differences in reduction and/or calcification of 


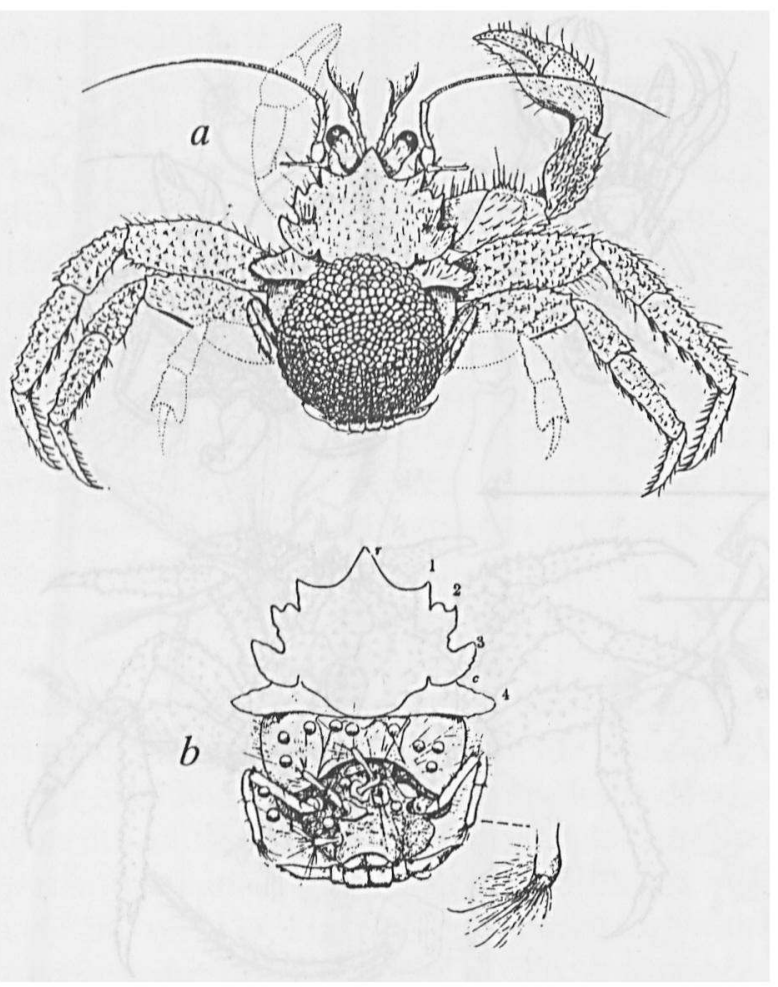

Fig. 5. Porcellanopagurus Filhol, 1885, "probably" P. edwardsi Filhol, 1885, as viewed by Borradaile (1916): a, ovigerous female, dorsal view; $b$, same after removal of most eggs (end of fifth leg shown enlarged). Abbreviations: c, cervical groove; $r$, rostrum. Numbers are "sidelobes" of cephalothorax. (After Borradaile, 1916.)

the abdomens. He set Porcellanopagurus apart by what he perceived to be the unique dorsal position of the female pleopods, and began his discourse with a detailed description of a female attributed "probably" to Porcellanopagurus edwardsi Filhol, 1885. Forest (1951a, b) redescribed $P$. edwardsi and discussed its systematic position within the Paguridae, but did not address any aspects of carcinization.

For the purpose of the current discussion, we present a brief morphological overview of Porcellanopagurus, based on our own examination of P. edwardsi. The cephalothorax (Fig. $7 \mathrm{a}, \mathrm{c}$ ) is broadened, flattened and drawn out into a series of lobes, the centermost being the prominent rostrum (r). Borradaile (1916) and Forest (1951a) identified the remaining lobes only by number; however, we believe that the anterolateral lobes represent extraordinarily well-developed lateral projections (lp) of the typical pagurid shield (Fig. $7 \mathrm{~b})$. The first two of the three lateral wing-like expansions appear to be expansions of the lateral margin of the shield itself. The third, and most posterior lobe, which is clearly delineated from the other two by the cervical groove (cg), is probably a calcified and expanded portion of the posterior carapace.

The hard strip of cuticle present directly behind the midpoint of the posterior margin of the carapace was considered by Borradaile (1916: 114, fig. 13a) to be a portion of the last thoracic somite. Forest (1951a) reported that the last thoracic tergite was represented by a narrow chitinous band, and we concur. As may be seen in Fig. $7 \mathrm{~d}$, a transverse calcified band is also apparent behind the posterior carapace margin. In our specimens there is a clear demarcation between the chitinous last thoracic segment (as determined by the positions of the acetabula of the fifth pereiopods) and the tergite containing the calcified strip, which we interpret to be a calcified portion of the tergite of the first abdominal somite. Borradaile (1916) reported two tergal sclerites present on the second abdominal somite and single plates on the left third and fourth somites, with only faint thickenings on the right. However, both Forest (1951a) and we were able to distinguish well-formed, entire (albeit not calcified), tergal plates on somites 2-5 (Fig. 7d) in both males and females. A more significant point is the structure and placement of the female unpaired pleopods. Borradaile (1916) and Forest (1951a) both stated that the female pleopodal endopods are well developed and the exopods reduced. Borradaile (1916) also considered the pleopods to be dorsal in position, with pl 2 almost median and the other two positioned successively more to the left, indicating a position analogous to that of a spirally twisted abdomen. One might well be drawn to this conclusion if the abdomen were partially contracted, as in many preserved specimens. However, when the abdomen is preserved in a relatively relaxed state, it is clear that the pleopods (p12-p14) as well as the uropods sit in a straight line on a symmetrical, albeit greatly swollen abdomen (Figs. 6e, 7d). In a small female specimen with the pleopods aligned in the normal 


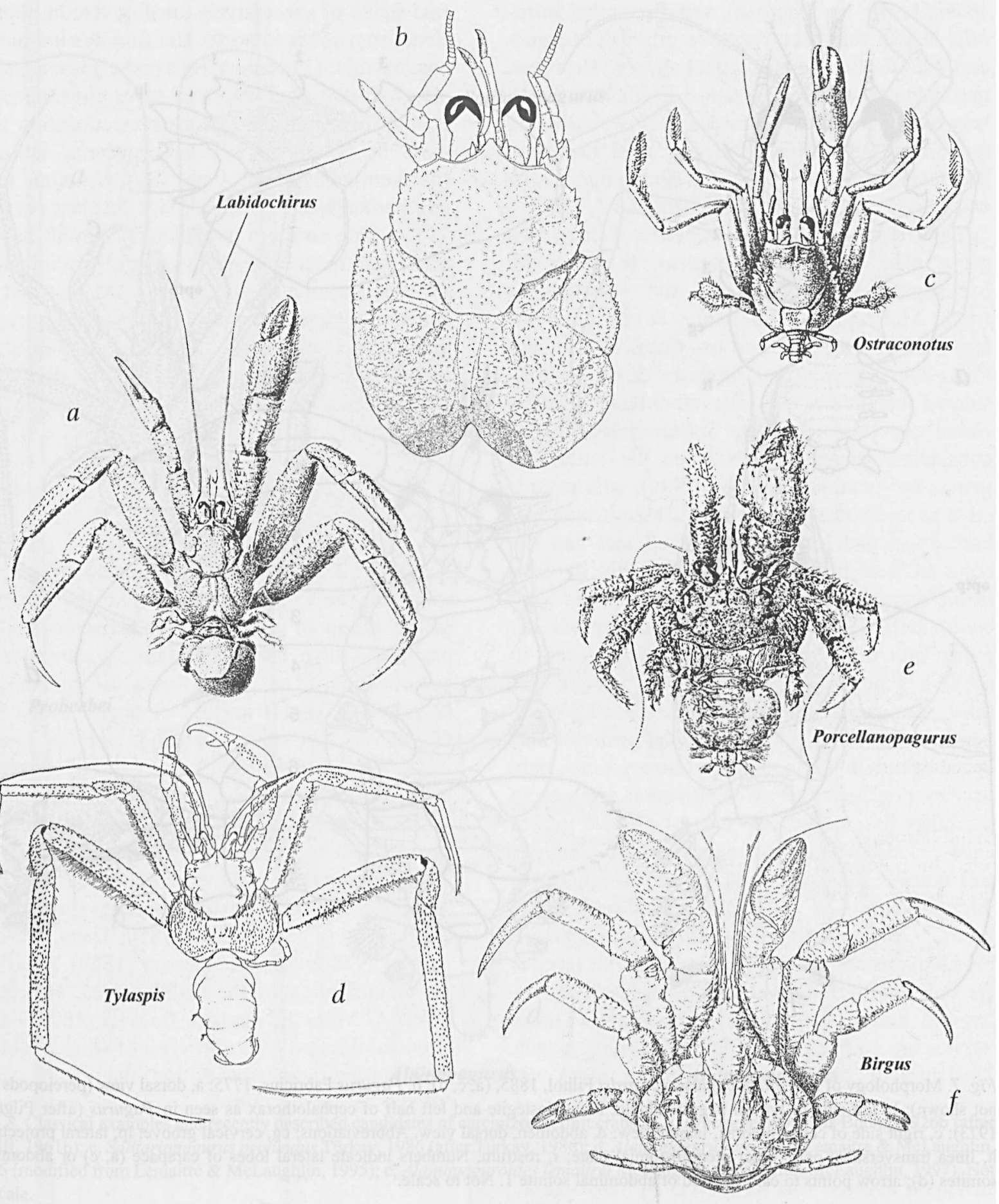

Fig. 6. Examples of advanced cases of carcinization in hermit crabs according to Borradaile (1916). Labidochirus splendescens (Owen, 1839): a, whole animal; b, cephalothorax and cephalic appendages (after McLaughlin, 1974); c, Ostraconotus spatulipes A. Milne Edwards, 1880 (after A. Milne Edwards \& Bouvier, 1893); d, Tylaspis anomala Henderson, 1888 (after Lemaitre, in press); e, Porcellanopagurus edwardsi Filhol, 1885 (after Forest, 1951a); f, Birgus latro (Linnaeus, 1758) (after Alcock, 1905). Not to scale. 

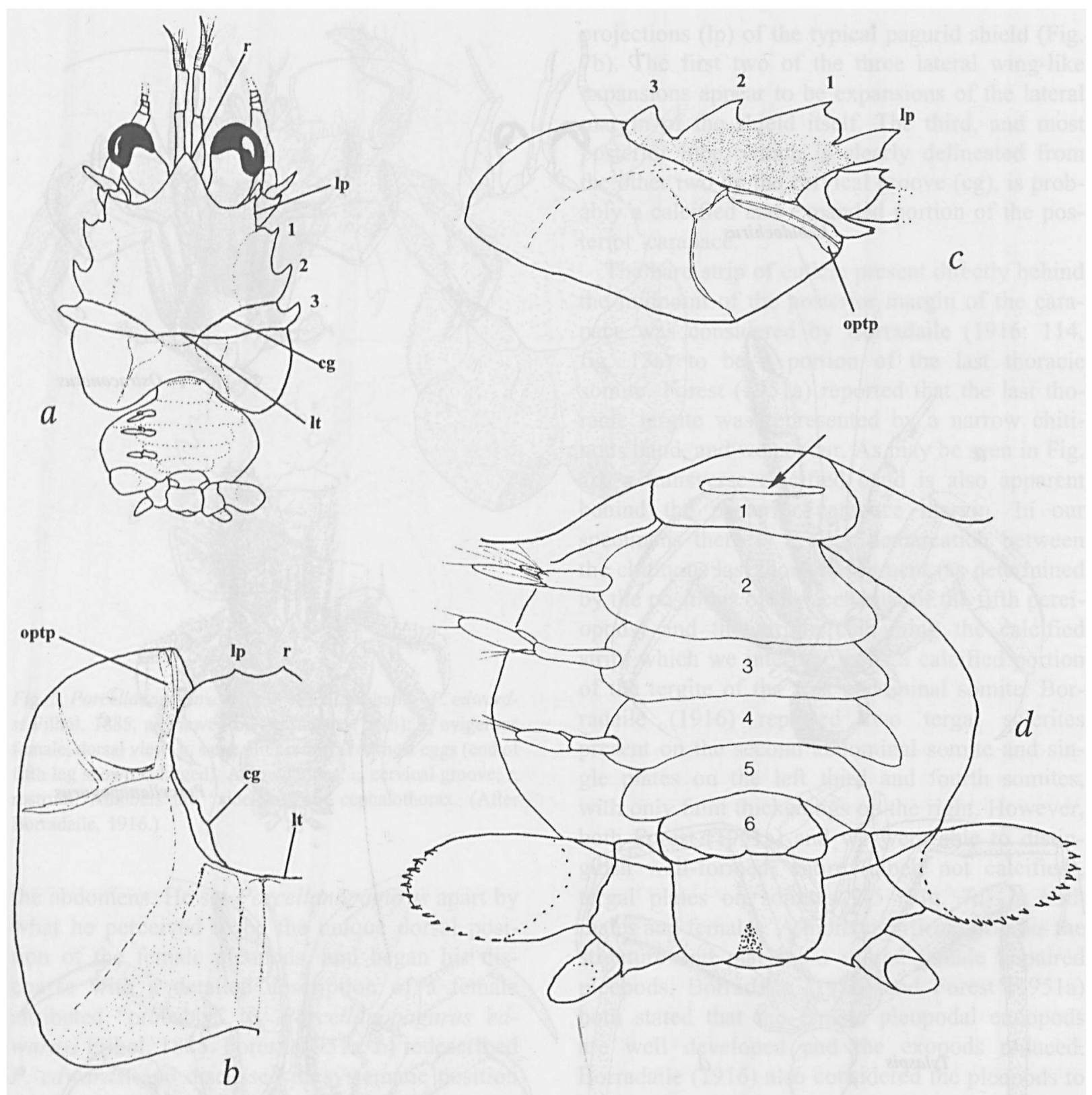

Fig. 7. Morphology of Porcellanopagurus edwardsi Filhol, 1885, (a, c, d); b: Pagurus Fabricius, 1775: a, dorsal view (pereiopods 1-5 not shown); b, left side of typical pagurid shield, branchiostegite and left half of cephalothorax as seen in Pagurus (after Pilgrim, 1973); c, right side of cephalothorax, lateral view; d, abdomen, dorsal view. Abbreviations: cg, cervical groove; lp, lateral projection; lt, linea transversalis; optp, outer pterygostomial plate; $r$, rostrum. Numbers indicate lateral lobes of carapace (a, c) or abdominal somites (d); arrow points to calcified rod of abdominal somite 1 . Not to scale.

lateral position, it is the endopod that is reduced. When the pleopods have eggs attached, the pleopods are twisted to allow the eggs to be carried dorsally; therefore the impression is given that it is the exopod that has undergone reduction.

Boone (1926a, b) described what she believed to be a new and primitive macruran representing a new family of decapods. In his redescription of 


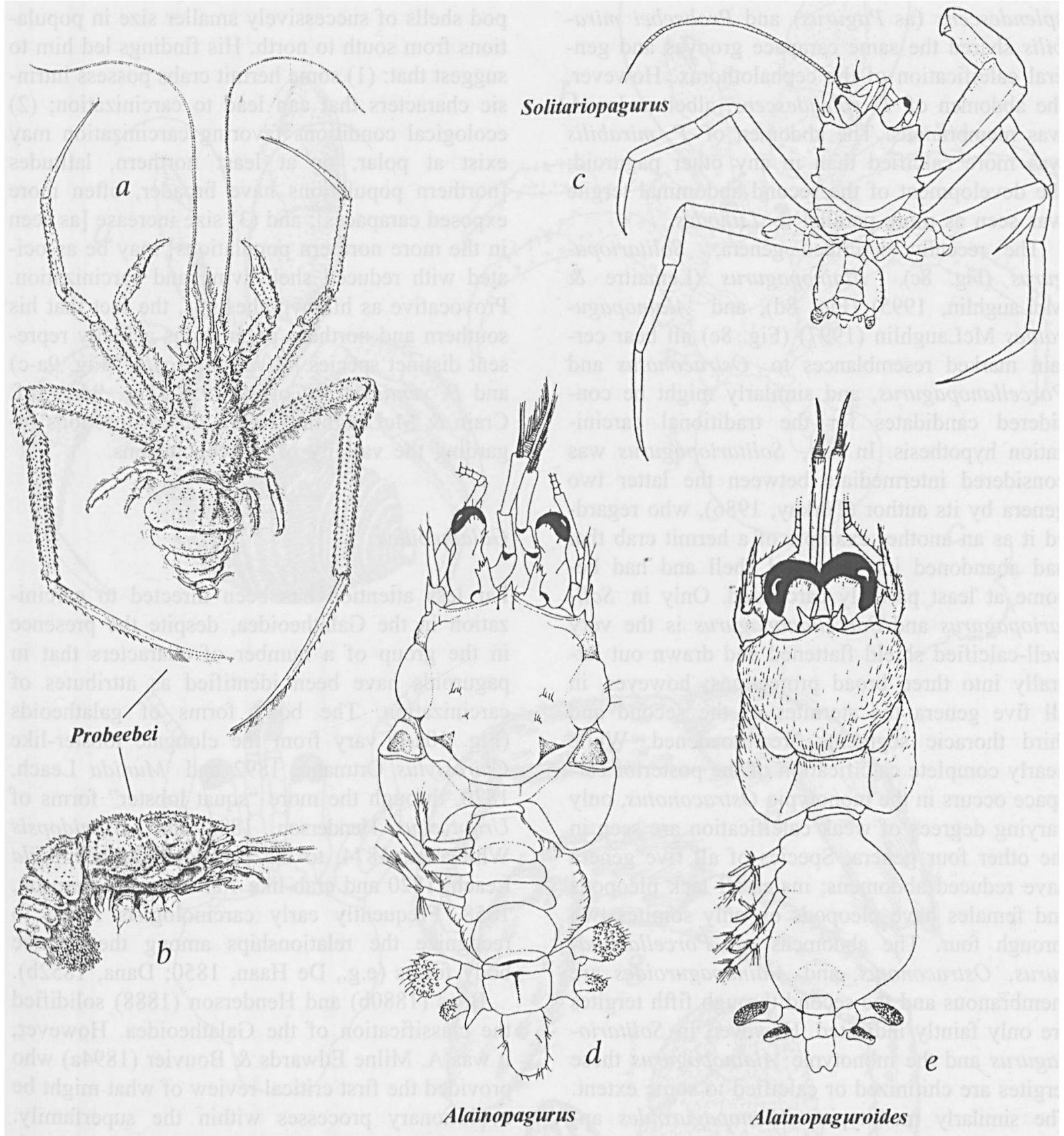

Fig. 8. Classical examples and recently described candidates of carcinized hermit crabs: a, b, Probeebei mirabilis Boone, 1926b (after Wolff, 1961b); c, Solitariopagurus profundus Türkay, 1986 (after Türkay, 1986); d, Alainopagurus crosnieri Lemaitre \& McLaughlin, 1995 (modified from Lemaitre \& McLaughlin, 1995); e, Alainopaguroides lemaitrei McLaughlin, 1997 (after McLaughlin, 1997). Not to scale.

Probeebei mirabilis Boone, 1926b, Wolff (1961a, b) correctly recognized this unusual, deep-water species as a paguroid (Fig. 8a, b), and he interpreted it as another example of carcinization within the group. Although he relied heavily on Borradaile's (1916) carcinization hypothesis, Wolff (1961b) did address abdominal changes in considerable detail. He noted that Labidochirus 
splendescens (as Pagurus) and Probeebei mirabilis shared the same carapace grooves and general calcification of the cephalothorax. However, the abdomen of $L$. splendescens, albeit reduced, was membranous. The abdomen of $P$. mirabilis was more calcified than in any other paguroid; the development of the second abdominal tergite was seen as more parallel to Lithodes.

The recently described genera, Solitariopagurus (Fig. 8c), Alainopagurus (Lemaitre \& McLaughlin, 1995) (Fig. 8d), and Alainopaguroides McLaughlin (1997) (Fig. 8e) all bear certain marked resemblances to Ostraconotus and Porcellanopagurus, and similarly might be considered candidates for the traditional carcinization hypothesis. In fact, Solitariopagurus was considered intermediate between the latter two genera by its author (Türkay, 1986), who regarded it as an another example of a hermit crab that had abandoned its gastropod shell and had become at least partially carcinized. Only in Solitariopagurus and Porcellanopagurus is the very well-calcified shield flattened and drawn out laterally into three broad projections; however, in all five genera the sternites of the second and third thoracic segments are broadened. While nearly complete calcification of the posterior carapace occurs in the monotypic Ostraconotus, only varying degrees of weak calcification are seen in the other four genera. Species of all five genera have reduced abdomens; males all lack pleopods and females have pleopods on only somites two through four. The abdomens of Porcellanopagurus, Ostraconotus, and Alainopaguroides are membranous and the second through fifth tergites are only faintly indicated. However, in Solitariopagurus and the monotypic Alainopagurus these tergites are chitinized or calcified to some extent. The similarly monotypic Alainopaguroides appears to be the only one to inhabit a gastropod shell.

An interesting hypothesis of carcinization involving Pagurus was proposed by Blackstone (1989). In what he reported to be southern and northern populations of the common, eastern $\mathrm{Pa}$ cific, intertidal hermit crab, Pagurus hirsutiusculus (Dana, 1851) (Fig. 9a, b), Blackstone documented the progressive broadening of the anterior calcified carapace (shield), and the use of gastro- pod shells of successively smaller size in populations from south to north. His findings led him to suggest that: (1) some hermit crabs possess intrinsic characters that can lead to carcinization; (2) ecological conditions favoring carcinization may exist at polar, or at least northern, latitudes [northern populations have broader, often more exposed carapaces]; and (3) size increase [as seen in the more northern populations] may be associated with reduced shell-living and carcinization. Provocative as his hypothesis is, the fact that his southern and northern populations actually represent distinct species $[P$. hirsutiusculus (Fig. 9a-c) and $P$. venturensis Coffin, 1957 (Fig. 9d-i) (cf. Crain \& McLaughlin, 1994)] raises questions regarding the validity of his conclusions.

\section{Galatheoidea}

Far less attention has been directed to carcinization in the Galatheoidea, despite the presence in the group of a number of characters that in paguroids have been identified as attributes of carcinization. The body forms of galatheoids (Fig. 10a-f) vary from the elongate lobster-like Chirostylus Ortmann, 1892 and Munida Leach, 1820 , through the more "squat lobster" forms of Uroptychus Henderson, 1888 and Munidopsis Whiteaves, 1874, to the pseudo crab-like Aegla Leach, 1820 and crab-like Petrolisthes Stimpson, 1858. Frequently early carcinologists failed to recognize the relationships among these three body forms (e.g., De Haan, 1850; Dana, 1852b).

Boas (1880b) and Henderson (1888) solidified the classification of the Galatheoidea. However, it was A. Milne Edwards \& Bouvier (1894a) who provided the first critical review of what might be evolutionary processes within the superfamily. Despite Bouvier's (1894a, b, c) concurrent work to derive the crab-like lithodids from the pagurids through a series of morphological analogies, $\mathbf{A}$.

Fig. 9. Pagurus hirsutiusculus Dana, 1851) (a-c): a, animal in shell (after Schmitt, 1921); b, animal removed from shell; c, telson (after Hart, 1982). Pagurus venturensis Coffin, 1957 (d-i) (after Crain \& McLaughlin, 1994); d, shield and cephalic appendages; $e$, right chelipede; $f$, left chelipede; $g$, right second pereiopod; $h$, left third pereiopod; $i$, telson. Not to scale. 

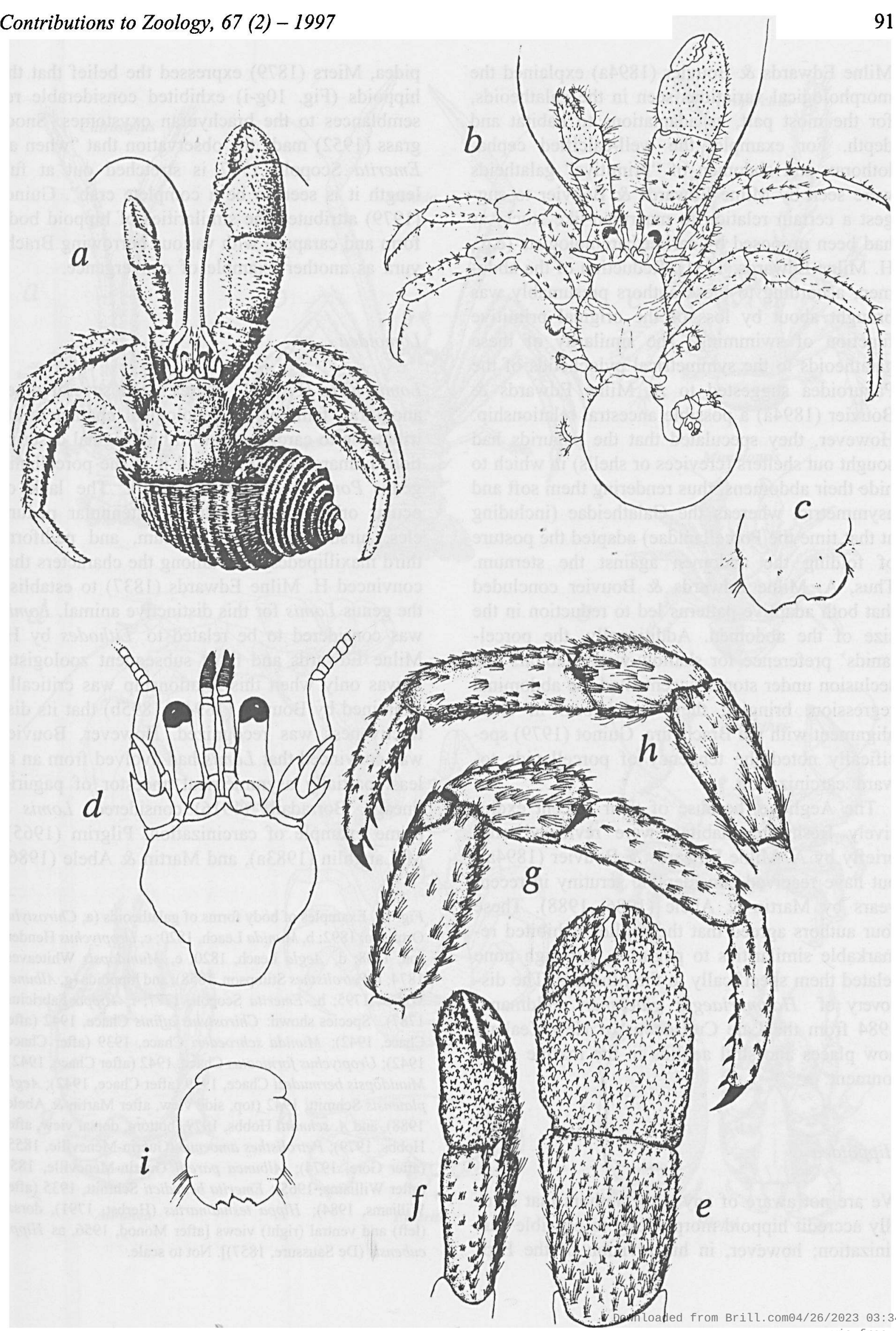
Milne Edwards \& Bouvier (1894a) explained the morphological variations seen in the galatheoids, for the most part, as adaptations to habitat and depth. For example, the well-calcified cephalothorax and abdomen of "primitive" galatheids were seen by Milne Edwards \& Bouvier to suggest a certain relation to macruran-like stock, as had been proposed by earlier carcinologists (e.g., H. Milne Edwards, 1831). Reduction of the abdomen, according to these authors presumably was brought about by loss of the original primitive function of swimming. The similarity of these galatheoids to the symmetrical pylochelids of the Paguroidea suggested to A. Milne Edwards \& Bouvier (1894a) a possible ancestral relationship. However, they speculated that the pagurids had sought out shelters (crevices or shells) in which to hide their abdomens, thus rendering them soft and asymmetric, whereas the Galatheidae (including at that time the Porcellanidae) adapted the posture of folding the abdomen against the sternum. Thus, A. Milne Edwards \& Bouvier concluded that both adaptive patterns led to reduction in the size of the abdomen. Additionally, the porcellanids" preference for shallow-water habitats and seclusion under stones accentuated the abdominal regression, bringing their body form in close alignment with the Brachyura. Guinot (1979) specifically noted the tendency of porcellanids toward carcinization.

The Aeglidae, because of their Recent exclusively freshwater habitat, were reviewed only briefly by A. Milne Edwards \& Bouvier (1894a), but have received considerable scrutiny in recent years by Martin \& Abele (1986, 1988). These four authors agreed that the aeglids exhibited remarkable similarities to pagurids, although none related them specifically to the lithodids. The discovery of Haumuriaegla glaessneri Feldmann, 1984 from the Late Cretaceous of New Zealand now places ancestral aeglids in the marine environment.

\section{Hippoidea}

We are not aware of any early authors that actually accredit hippoid morphology to possible carcinization; however, in his revision of the Hip- pidea, Miers (1879) expressed the belief that the hippoids (Fig. 10g-i) exhibited considerable resemblances to the brachyuran oxystomes. Snodgrass (1952) made the observation that "when an Emerita Scopoli, 1777 is stretched out at full length it is seen to be a complete crab". Guinot (1979) attributed the similarities of hippoid body form and carapace with various burrowing Brachyura as another example of convergence.

\section{Lomoidea}

Lomis hirta (Fig. 11) shares, with several other anomuran families, morphological characters attributable to carcinization. In his original description, Lamarck (1818) placed it in the porcellanid genus Porcellana Lamarck, 1801. The lack of ocular orbits, the cylindrical antennular peduncles, hirsute antennal flagellum, and pediform third maxillipedes were among the characters that convinced H. Milne Edwards (1837) to establish the genus Lomis for this distinctive animal. Lomis was considered to be related to Lithodes by $\mathrm{H}$. Milne Edwards and most subsequent zoologists. It was only when this relationship was critically examined by Bouvier (1894a, 1895b) that its distinctiveness was recognized. However, Bouvier was convinced that Lomis had evolved from an at least partially asymmetrical ancestor of pagurid lineage. Borradaile (1916) considered Lomis a prime example of carcinization. Pilgrim (1965), McLaughlin (1983a), and Martin \& Abele (1986)

Fig. 10. Examples of body forms of galatheoids (a, Chirostylus Ortmann, 1892; b, Munida Leach, 1820; c, Uroptychus Henderson, 1888; d, Aegla Leach, 1820; e, Munidopsis Whiteaves, 1874; f, Petrolisthes Stimpson, 1858), and hippoids ( $\mathrm{g}$, Albunea Weber, 1795; h, Emerita Scopoli, 1777; i, Hippa Fabricius, 1787). Species shown: Chirostylus affinis Chace, 1942 (after Chace, 1942); Munida schroederi Chace, 1939 (after Chace, 1942); Uroptychus fornicatus Chace, 1942 (after Chace, 1942); Munidopsis bermudezi Chace, 1939 (after Chace, 1942); Aegla platensis Schmitt, 1942 (top, side view, after Martin \& Abele, 1988), and A. schmitti Hobbs, 1979 (bottom, dorsal view, after Hobbs, 1979); Petrolisthes amoenus (Guérin-Méneville, 1855) (after Gore, 1974); Albunea paretii Guérin-Méneville, 1853 (after Williams, 1965); Emerita benedicti Schmitt, 1935 (after Williams, 1984); Hippa testudinarius (Herbst, 1791), dorsal (left) and ventral (right) views [after Monod, 1956, as Hippa cubensis (De Sáussure, 1857)]. Not to scale. 


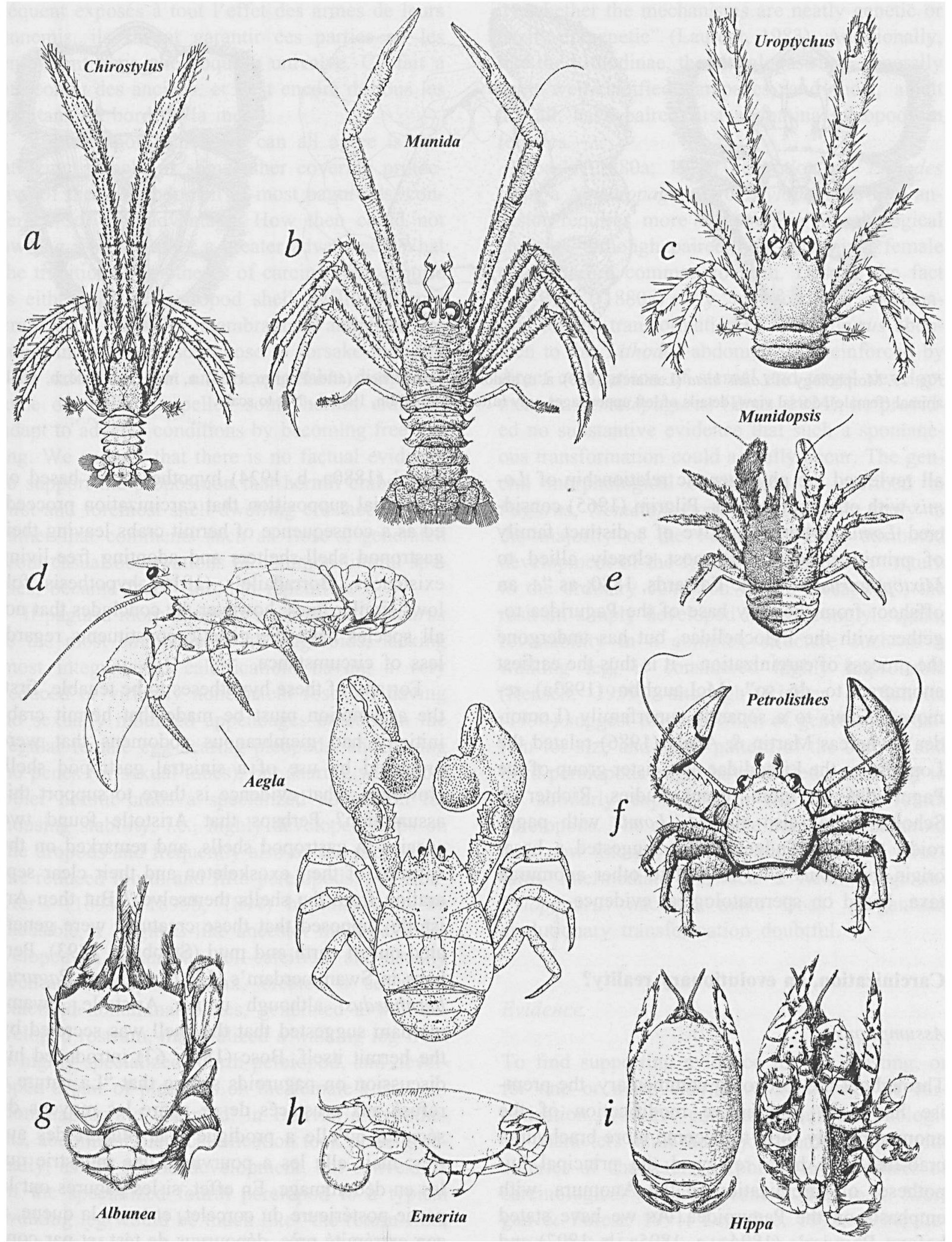



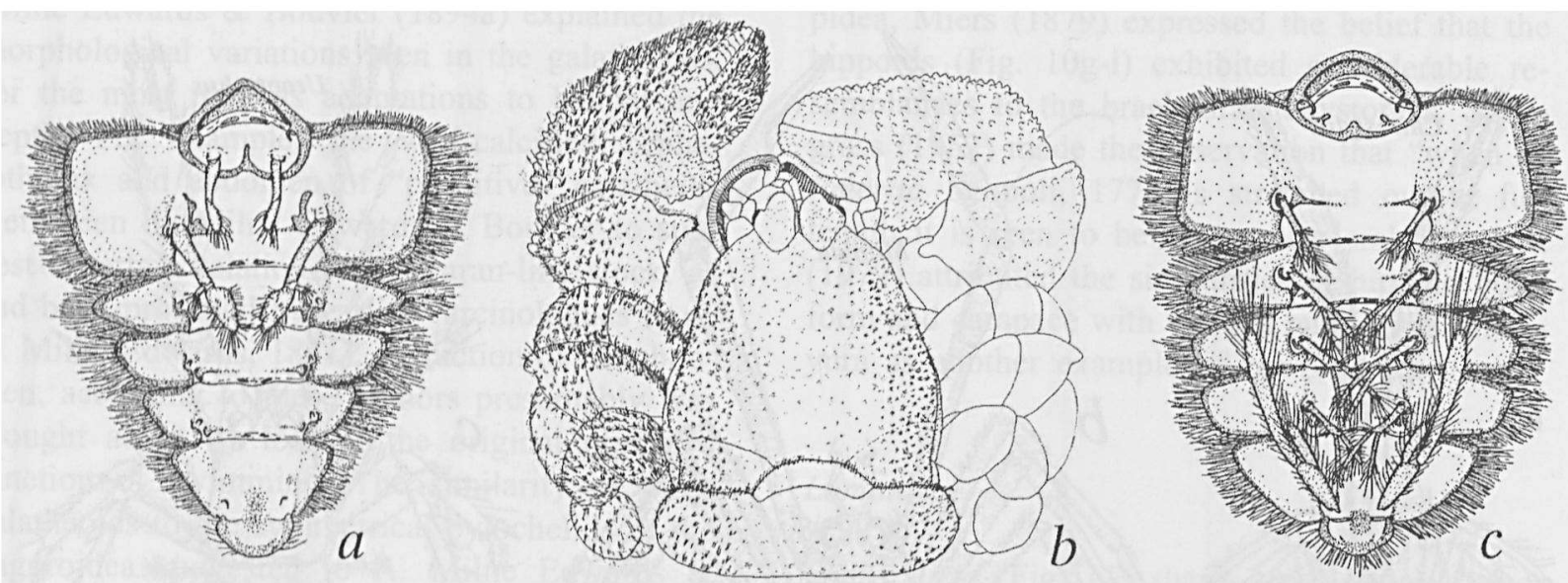

Fig. 11. Morphology of Lomis hirta (Lamarck, 1818). a, c, abdomen, ventral view (after Pilgrim, 1965): a, male; c, female; b, whole animal (female), dorsal view, details of left appendages only (after McLaughlin, 1983a). Not to scale.

all reviewed the phylogenetic relationship of $L O-$ mis with other anomurans. Pilgrim (1965) considered Lomis as representative of a distinct family of primitive paguroids, most closely allied to Mixtopagurus A. Milne Edwards, 1880, as “... an offshoot from the very base of the Paguridea together with the Pylochelidae, but has undergone the process of carcinization - it is thus the earliest anomuran to do so". McLaughlin (1983a) removed Lomis to a separate superfamily (Lomoidea); whereas Martin \& Abele (1986) related the Lomidae to the Lithodidae as a sister group of the Paguroidea. In more recent studies, Richter \& Scholtz (1994) also aligned Lomis with paguroids, whereas Tudge (1997) suggested a basal origin for Lomis with respect to other anomuran | taxa, based on spermatological evidence.

\section{Carcinization, an evolutionary reality?}

\section{Assumptions}

Throughout the foregoing commentary, the premise has been progressive modification of the anomuran body form to become more brachyuran crab-like. We have reviewed the principal hypotheses of carcinization in the Anomura, with emphasis on the Paguroidea. As we have stated before, Bouvier's (1894a, c, 1895a, b, 1897) and
Boas' (1880a, b, 1924) hypotheses are based on the initial supposition that carcinization proceeded as a consequence of hermit crabs leaving their gastropod shell-shelters and adopting free-living existences. Borradaile's (1916) hypothesis follows similar lines; however, he concludes that not all species have the genetic constituents regardless of circumstance.

For any of these hypotheses to be tenable, first, the assumption must be made that hermit crabs initially had membranous abdomens that were protected by use of a sinistral gastropod shell. However, what evidence is there to support this assumption? Perhaps that Aristotle found two species in gastropod shells, and remarked on the softness of their exoskeleton and their clear separation from the shells themselves? But then Aristotle supposed that these creatures were generated out of earth and mud (Stebbing, 1893). Perhaps in Swammerdam's (1737) study of Pagurus bernhardus, although unlike Aristotle, Swammerdam suggested that the shell was secreted by the hermit itself. Bosc (1802: 63) introduced his discussion on paguroids saying that "La nature a refusé aux crustacés de ce genre les moyens de sécurité qu'elle a prodigué à la plupart des autres; mais elle les a pourvus d'une industrie qui les en dédommage. En effet, si les pagures ont la partie postérieure du corcelet, et toute la queue, à son extrémité près, dépourvus de test, et par con- 
séquent exposés à tout l'effet des armes de leurs ennemis, ils savent garantir ces parties en les enfermant dans une coquille univalve. Ce fait a été connu des anciens, et l'est encore de tous les habitans du bord de la mer."

A point upon which we can all agree is that utilizing a shell, or some other covering protective of the soft abdomen of most paguroids, confers a survival advantage. How then could not owning a shell confer a greater advantage? What the traditional hypotheses of carcinization require is either: that a gastropod shell-dwelling hermit crab with a totally membranous abdomen for some inexplicit reason chose to forsake mobility with safety, or that an unexplainable disappearance of shells compelled some hermit crabs to adapt to adverse conditions by becoming free living. We suggest that there is no factual evidence to support the proposition that hermit crabs were first and foremost shell-dwelling crustaceans, but rather that comments such as Bosc's, generated from casual observations of common littoral species, became "fact" through repetition.

If pagurid morphology is reexamined, Pagurus is the most simplistic of all paguroids, lacking most integumental calcification; having a very reduced or virtually nonexistent rostrum; having no sexually modified appendages other than the regular female egg-bearing pleopods, and having no penes (or sexual tubes), but sharing with most other hermit crabs a specialized adaptation for housing stability, i.e., highly developed rasps on the uropods and frequently also on the propodi of the reduced fourth and fifth pereiopods. For Bouvier's $(1894 c, 1895 b, 1897)$ hypothesis to be plausible, a Pagurus-like ancestor must have developed an expanded, well-calcified, and usually well-armed cephalothorax, created a series of calcified abdominal plates, generated a well-developed rostrum, materialized a walking leg from a highly specialized fourth pereiopod, and developed a pair of pleopods on the female's first abdominal somite. Granted, in Bouvier's hypothesis, abdominal plate calcification took place gradually, as did rostral development, but conversion of the specialized fourth pereiopod to a typical walking leg would be much like "the return from Equus to Hyracotherium ... a practical impossibil- ity whether the mechanisms are neatly genetic or hazily epigenetic" (Laurent, 1983). Additionally, like the Lithodinae, the Hapalogastrinae generally have well-calcified carapaces, and most, albeit not all, have paired first abdominal pleopods in females.

Boas's (1880a; 1924) derivation of Lithodes from a Nematopagurus- or Pylopagurus-like ancestor requires more catastrophic morphological changes, although paired first abdominal female pleopods are common to both. Despite the fact that Boas' (1880a) early "rags to riches" explanation for the transformation of the Pagurus abdomen to the Lithodes abdomen was reinforced by direct comparison of sternal and tergal development in Nematopagurus (Boas, 1924), he provided no substantive evidence that such a spontaneous transformation could actually occur. The general morphological similarities he ascribed to Pagurus, Nematopagurus and Lithodes apply to the majority of the Paguridae. Boas attributed development of the fourth pereiopod as a "return to the ordinary condition of the Decapoda"; the rostrum simply developed more strongly. Again, reversibility in a complex structure such as a walking leg, is considered highly improbable (Rensch, 1959), although Richter \& Scholtz (1994) suggest that repetition of genetic information for size and spine pattern of the second and third pereiopods might have shifted posteriorly to be similarly expressed in the lithodid fourth pereiopods. The considerable number of paguroid taxa now known that have morphological structures intermediate between a NematopagurusPylopagurus ancestor make Boas' gargantuan evolutionary transformation doubtful.

\section{Evidence}

To find supporting evidence for the existing, or for one or more alternative hypotheses of carcinization, we have compared adult morphological characters in all the major anomuran taxa with a series of characters purported to be indices of carcinological trends. Recent studies (e.g., Morgan \& Forest, 1991; Lemaitre, 1993, 1994; Lemaitre \& McLaughlin, 1995; Poupin \& McLaugh- 
lin, 1996; McLaughlin, 1997) have enabled us to include characters from a number of paguroid taxa not available to earlier carcinologists. Although we have used examples from galatheoids, hippoids and Lomis, as well as paguroids, this is not meant to imply that a continuum is to be expected. It is quite probable that if carcinization does occur, it does so through convergent pathways.

\section{Characters}

Morphological attributes of carcinization (i.e., leading to or producing a brachyuran-like crab body form) have been compiled from Bourne (1922), Števčić (1971), and Guinot (1979) and include 19 categories. Five additional attributes of those proposed by Richter \& Scholtz (1994) have been examined. While our major morphological categories have been selected specifically because of their presumed evolutionary role in carcinization, the pertinence of individual elements may not always be clearly evident. For example, paired first and second male, and paired first female pleopods would not appear particularly relevant. However, the total array of characters utilized is essential in allowing a clearer picture of evolutionary pathways to emerge.

Our assessment of attributes employs cladistic methods, but it must be pointed out that not only is this only a preliminary and partial analysis, but also we are aware of the rather unusual application of cladistics to this study. By examining the possible evolutionary pathways of a set of adult morphological characters, we are attempting to ascertain whether or not carcinization in the Anomura is an authentic phenomenon rather than determine now the precise phylogenetic relationships among taxa. A thorough assessment of these pathways can only be made when larval and juvenile characters are similarly addressed, as they will be in the second part of this review.

For our present study, we have used the "outgroup" concept to root our analysis. In studies of evolutionary relationships within and among anomuran taxa, McLaughlin (1983b) and Richter \& Scholtz (1994) utilized other anomuran and general reptant characters to establish polarities, whereas Martin \& Abele (1986) used the character states found in the pelagic shrimp genus $\mathrm{Pe}$ naeus Fabricius, 1798. Neither approach is appropriate to the present investigation. In the first instance, McLaughlin's (1983b) assessment was essentially intuitive, not a disciplined cladistic analysis. Richter \& Scholtz (1994) based their out-group comparison on information gathered from the Galatheoidea, Hippoidea, Lomoidea, and other, unspecified reptant decapods. Since we are considering these three superfamilies in our investigation, they represent components of our overall "in-group", thus they are not appropriate to serve as out-groups. Martin \& Abele (1986) used Penaeus as an out-group "because the characters of the Dendrobranchiata are conceded by most workers to be primitive relative to other infraorders ...". This undoubtedly is true, but in reviewing Martin \& Abele's discussion of characters, we were unable to find any synapomorphies shared by Penaeus with the taxa under consideration that would qualify it as an out-group in our search for evolutionary pathways of carcinization. Rather we have chosen Neoglyphea inopinata Forest \& De Saint Laurent, 1975 as our outgroup.

Specific information on $N$. inopinata has been gleaned from Forest \& De Saint Laurent (1981); interpretation and choice of an out-group is based on the guidelines of Nixon \& Carpenter (1993). That many of $N$. inopinata's morphological attributes are plesiomorphic was demonstrated by (Poore (1994). However, N. inopinata is not a sister group to the Anomura (cf. De Saint Laurent, 1979), nor is it considered as "The" ancestor to the Anomura. Nevertheless, the synapomorphy, reduction in the length of the fifth pereiopods, shared by $N$. inopinata and all anomurans supports our choice of it as our out-group. Table I provides a summary of characters and states. Table II furnishes, with $N$. inopinata as the outgroup, a list of anomuran taxa examined and their respective character states.

In the discussion that follows, references are made to various genera, but it must be pointed out that in many cases, particularly among galatheoid and hippoid- taxa, data have been obtained 
through personal examinations of a limited number of individual species. When possible, these data have been supplemented with published accounts of related taxa. Characters of paguroid genera reflect the overall sense of the genera as currently interpreted, although intrageneric variations do exist. For example, the diogenid genus Paguristes Dana, 1851 is characterized by the presence of paired first and second pleopods modified as gonopods in males and paired, similarly modified, first pleopods in females; however, we recognize that there are exceptions. Such incongruities reflect deficiencies in the alpha level taxonomy of the groups but do not present any major obstacles to the interpretations of carcinizational pathways.

\section{Characters and/or character states}

\section{Broadening and flattening of carapace, sternal} plates, buccal frame and eventually also the branchial chamber. Six characters are considered in this category, most of which are generally self explanatory. The exception is that of carapace shape. The character states of carapace shape given in this account may differ significantly from other published accounts. For example, Martin \& Abele (1988) referred to the carapace of Aegla as being extremely depressed, giving the animal an overall flattened appearance, whereas we have scored the Aegla carapace as vaulted.

1a. - Carapace shape. We have recognized four character states. The primitive subcylindrical carapace is most closely approached in the hippoid family Hippidae and the similarly sanddwelling Euceramus Stimpson, 1860 of the galatheoid family Porcellanidae. It is probable that the burrowing habits of these animals may be as much a contributing factor to their carapace shape as the possible retention of the primitive character state. Virtually all other anomurans exhibit some more extensive degree of dorsoventral compression of the cephalothorax. We have defined three character states to depict the transition away from the primitive subcylindrical cephalothorax: (1) "globular", in which the cephalothorax usually is not considerably longer than broad, is moderately deep, and has generally rounded carapace margins; (2) "vaulted", in which the relatively straight lateral faces of the carapace and branchiostegites provide the impression of an arciform carapace; (3) "flattened", representing the state where there is relatively little lateral depth to the cephalothorax.

Within the remaining examined paguroid genera, Pylocheles A. Milne Edwards, 1880 and Cheiroplatea Bate, 1888 among the Pylochelidae, Cancellus H. Milne Edwards, 1836 among the Diogenidae, and Pylopagurus and Xylopagurus A. Milne Edwards, 1880 among the Paguridae, still retain a somewhat subcylindrical carapace shape; however, it is most probable that habitat preferences have strongly influenced carapace shape in these genera, rather than retention of the plesiomorphic condition. All generally are petricolous,- xylicolous, spongicolous or scaphopod shell dwellers. As may be seen in Table II, the evolution to a more "crab-like" form is reflected in those taxa in which the carapace is globular or vaulted, i.e., Birgus Leach, 1815 and Coenobita Latreille, 1829 in the Coenobitidae, Paguropsis Henderson, 1888 and Tisea Morgan \& Forest, 1991 in the Diogenidae, the presumably "partially carcinized" Paguridae, Solitariopagurus, Porcellanopagurus, Ostraconotus, Alainopagurus, Alainopaguroides, Icelopagurus McLaughlin, 1997, Labidochirus, and Lithopagurus Provenzano, 1968, as well as all of the Parapaguridae and Lithodidae.

Although commonly thought of as having subcylindrical carapaces, not all hippoids do exhibit this character. Carapaces of two of the four genera sampled had the more "crab-like" globular to vaulted carapace structure. Representatives of the Galatheoidea are even more variable. In the porcellanids, the carapace is subcylindrical in Euceramus, but globular in Polyonyx Stimpson, 1858, and flattened in Petrocheles Miers, 1876 and Petrolisthes Stimpson, 1858. Carapace shape is seen as globular in the chirostylid Gastroptychus Caullery, 1896, but vaulted in Uroptychus, whereas in the galatheids the distinction was less definitive. Carapace shape in Galathea Fabricius, 1793, Munida and Munidopsis is neither globular, nor vaulted, but rather intermediate. As previous- 
Table $I$. Characters for carcinization analysis. Paragraph numerals correspond to attributes of carcinization discussed in text (see Characters and/or character states). Character state symbols are in parentheses. Out-group $=$ Neoglyphea inopinata Forest \& De Saint Laurent; data from Forest \& De Saint Laurent (1981). Abbreviations: mxp, maxillipede; P, pereiopod.

1. Broadening and flattening of the carapace, sternal plates, buccal frame and eventually also the branchial chamber:

la. Carapace shape: subcylindrical (0); globular (1); vaulted (2); flattened (3).

lb. Rostrum; elongate, broad basally and tapering to acute tip (0); elongate cylindrical or subcylindrical (1); long to moderately short, triangular or subtriangular (2); very short, bluntly triangular, rounded, obsolete, or absent (3).

lc. Lateral projections (postorbital spines); obsolete or absent (0); weakly developed (1); moderately well developed (2); elongate, prominent (3).

Id. Sternite of the third maxillipedes: narrow, bases of corresponding appendages contiguous or nearly so (0); broad, bases of corresponding appendages separated (1).

le. Sternite of chelipedes (fourth thoracic stemite): narrow, bases of corresponding appendages contiguous or nearly so (0); broadened, but maximum much less than half total carapace width, corresponding appendages neither approximate nor very widely separated (1); very broad, maximum nearly half total carapace or greater, corresponding appendages very widely separated (2).

1f. Sternite of third pereiopods (thoracic sternite 6): narrow, bases of corresponding appendages contiguous or nearly so (0); broadened, but much less than half total carapace width, corresponding appendages neither approximate nor very widely separated (1); very broad, nearly half total carapace or greater, corresponding appendages very widely separated (2).

2. Increased integumental calcification:

2a. Anterior carapace (shield): strongly calcified (0); moderately well calcified throughout (1); with areas of very weak or no calcification (2).

2b. Posterior carapace: entirely calcified (0); posterolateral and/or posteromedial calcification (1); entirely membranous or with only scattered small areas of calcification (2).

2c. Branchiostegites: calcified (0); partially calcified (1); membranous (2).

3. Abdomen:

3a. Abdominal orientation: elongate, straight (0); elongate, twisted (1); reduced, straight or twisted (2); reduced, folded beneath cephalothorax (3).

3b. Abdominal segmentation: 6 clearly defined somites (0); 6 distinguishable, but not clearly defined somites (1); fewer than 6 distinguishable somites (2).

3c. Tergite calcification: completely calcified (0); partially calcified (1); membranous or nearly so (2).

4. Uropods: Uropod structure: foliaceous, symmetrical (0); specialized, symmetrical (1); specialized, asymmetrical (2); absent (3).

5. Female pleopods:

5a. First pleopods: paired and modified as simple "gonopods" (0); paired, unmodified (1); unpaired (2); absent (3).

5b. Second pleopods: paired (0); unpaired, right or left (1); unpaired left only (2); absent (3).

5c. Third and fourth pleopods: paired (0); unpaired, right or left (1); unpaired left only (2); absent (3). * .

5d. Fifth pleopods: paired (0); unpaired right or left (1); unpaired left only (2); absent (3).

6. Posterior abdominal appendages of males:

6a. Third and fourth pleopods: paired (0); unpaired, right or lef (1); unpaired left only (2); rudimentary or vestigial (3); absent
(4),

6b. Fifth pleopods: paired (0); unpaired, right or left (1); unpaired left only (2); rudimentary or vestigial (3); absent (4).

9. Branchia:

9a. Arthrobranch formula: rudiment (mxpl), 1 (mxp2), 2 (mxp3), 2(P1), 2(P2), 2(P3), 2(P4), 0(P5) (0); 0,0,2,2,2,2,2,0 (1); $0,0,2,2,2,2,2,1(2) ; 0,0,1,2,2,2,2,0(3) ; 0,0,0,2,2,2,2,0$ (4).

9b. Pleurobranch formula: $0,0,0,0,1(\mathrm{P} 2), 1(\mathrm{P} 3)$, 1(P4), 1(P5) (0); $0,0,0,0,0,0,1,1,2(1) ; 0,0,0,0,1,1,1,0(2) ; 0,0,0,0,0,1,1,0(3)$; $0,0,0,0,0,0,0,1,1(4) ; 0,0,0,0,0,0,1,0(5) ; 0,0,0,0,0,0,0,1(6) ; 0,0,0,0,0,0,0,0(7)$.

9c. Gill structure: trichobranchiate (0); intermediate (1); phyllobranchiate (2).

10. Antennal scale (acicle/exopod): Antennal acicle: elongate, triangular, marginally armed (0); well developed, cylindrical, or blade-shaped, unarmed (1); reduced (2); absent (3).

12. Expansion of ischia and meri of third maxillipedes to form a plate-like covering over the other mouthparts:

12a. Expansion of ischium and merus: no expansion ( 0 ); some degree of expansion to partially cover other mouthparts (1); broadly expanded to form plate-like covering over other mouthparts (2).

12b. Accessory tooth (teeth): with accessory tooth (0); without accessory tooth (1); absent (2).

13. Ocular orbit development with accompanying reduction in the size of the antennules and antennae:

13a. Ocular orbits: no orbits developed (0); partial development of orbits (1); well-developed orbits (2).

13b. Antennular and antennal reduction; well developed, elongate (0); one or other reduced (1); both reduced (2). 
Table I. Cont.

14. Fusion of last thoracic somite: not fused to either abdomen or cephalothorax (0); fused to first abdominal somite (1); fused to cephalothorax (2)."

15. Position of dactyls of chelipedes: simple (0); subchelate (1); chelate, fingers opening horizontally (2); chelate, fingers opening obliquely (3); chelate, fingers opening vertically (4).

17. Development of first two pairs of pleopods in males:

17a. First pleopods: modified as complex copulatory appendages (0); present, not modified complex copulatory structures (1); absent (2).

17b. Second pleopods: paired, natatory, with appendix masculina (0); paired, modified as copulatory structures (1); unpaired, reduced (2); absent (3).

18. Development of male penes: Male gonopores: paired, unmodified (0); one or both masked by tuft of prominent setae (1); one or both with vas deferens produced as sexual tube (2).

Supplemental characters (Števčić, 1971; Wolff, 1961b; Ríchter \& Scholtz, 1994):

23. Development of the fourth pereiopod:

23a. Size and structure of third and fourth pereiopods: generally similar (0); dissimilar (1).

23b. Ventrolateral margin of propodus of fourth pereiopod: unarmed (0); row of spines (1); row of comeous scales or tubercles (2); multiple rows of comeous scales or tubercles (3).

23c. Fourth pereiopod termination: simple (0); subchelate (1); semichelate (2); chelate (3).

24. Position and structure of the fifth pereiopod:

24a. Fifth pereipod termination: simple (0); subchelate (1); semichelate (2); chelate (3).

24b. Propodus of fifth pereiopod: rows of setae or denticles (0); rasp of comeous scales (1).

Iy noted, we consider the aeglid carapace to be vaulted. The carapace of Lomis, like the galatheids, is neither strictly globular nor strictly vaulted.

1b. - Rostrum. Among anomuran taxa there is a great range of development. An elongate, basally broad, and tapering rostrum, such as seen in Neoglyphea Forest \& De Saint Laurent, 1975 is considered plesiomorphic, with reduction indicative of more advanced conditions. Retention of this type of rostrum in paguroids is seen only in Probeebei among the parapagurids and a few of the lithodid genera. It is reduced, but nonetheless prominent in Birgus. Throughout the Paguridae there is a clear tendency toward reduction in rostral length and strength.

The rostrum in hippoids is never very well developed, varying from moderately short in albuneids to very short in hippids. In contrast, the primitive elongate, triangular rostrum is seen in Aegla, Munidopsis, Galathea, and Uroptychus, with only moderately reduction in the other galatheid and chirostylid genera. However, the rostrum is moderately short to obsolete in all of the porcellanid genera examined. In Lomis the rostrum is moderately short as well.

1c. - Lateral projections. The role of the lateral projections, or post-antennal spines, of the carapace has not been fully investigated for any anomuran group. In some paguroid genera, development of the lateral projections appears to be correlated with carapace calcification, whereas in some of the galatheoids such as the porcellanids it would appear to correlate more directly with the development of ocular orbits. Since lateral projections and/or post-orbital spines are lacking in Neoglyphea (presumably plesiomorphic), we have scored their development as apomorphic.

Among paguroids, lateral projections are best developed in some of the lithodid genera, and obsolete or entirely lacking only in Cancellus, Probeebei and Tylaspis.

Among hippoids, galatheoids and Lomis, lateral projections vary from total absence to relatively strong development.

1d. - Sternite of the third maxillipedes. In the paguroid genera of the families Pylochelidae, Coenobitidae, and Diogenidae we see the assumed primitive condition of a very narrow sternite, with the corresponding appendages basally approximate, seen. In genera of the Paguridae, Parapaguridae, Lithodidae, all hippoids, and galatheoids, as well as Lomis, the bases of the third maxillipedes are separated. However, in Gastrop- 
tychus and Galathea, it is the articulating condyles that are separated; the basal segments of the maxillipedes themselves are nearly approximate.

1e. - Sternite of chelipedes (fourth thoracic sternite). While it might be expected that if the bases of the third maxillipedes were approximate, the bases of the following appendage pair, the chelipedes, would be similarly positioned or vice versa, and this is for the most part true in paguroids; however, there are exceptions. In the diogenid genera Clibanarius Dana, 1852a and Tisea, the chelipedes are separated, while the maxillipedes are approximate. In contrast, in the parapagurids Sympagurus Smith, 1883 (sensu Lemaitre, 1989), Parapagurus Smith, 1879, Bivalvopagurus Lemaitre, 1993, and Tsunogaipagurus Osawa, 1995, and the pagurid genera Enneopagurus McLaughlin, 1997, Pylopaguropsis Alcock, 1905, and Xylopagurus, the chelipede bases are approximate even though the maxillipedes are broadly separated by the sternal plate. There does not appear to be any clear correlation between carapace shape and the separation of either third maxillipedes or chelipedes.

The sternite of the chelipedes is narrow in all of the hippoids examined, and the chelipedes correspondingly approximate basally. Thus, it would appear that the breadth of this fourth sternite in hippids is not a function of carapace shape either: the sternite is narrow whether the carapace is either subcylindrical or globular-vaulted. In all galatheoid taxa examined, the fourth thoracic sternite is broad, even in porcellanid genera where the carapace varies from subcylindrical (Euceramus) to flattened (Petrolisthes and Petrocheles). A similar broadening of this sternite is also seen in Lomis.

1f. - Sternite of third pereiopods (thoracic sternite 6). In paguroids there does seem to be a relationship between carapace shape and the extent of the broadening of the sternite of the third pereiopods among pagurids and lithodids. With few exceptions, those taxa having globular or truncate carapaces similarly had very broad sixth sternites. Moderate broadening was seen in Coenobita. That was not the case however, for pylochelids, diogenids or parapagurids. Some taxa such as Ciliopagurus Forest, 1995, with species that occupy the very slender whorls of cone shells, exhibit markedly broad sternal plates, which reflect microhabitat influence; however, that phenomenon simply indicates the plasticity of hermits to adapt to their environment.

Only in the hippoid Blepharipoda Randall, 1840 is a modest broadening of the fifth and sixth thoracic sternites seen, which might or might not be associated with carapace shape. In contrast, Lomis and all galatheoids exhibit exceptionally broad sternal plates regardless of carapace shape.

2. Increased integumental calcification. The three characters considered in this category reflect, in part, the division of the cephalothorax seen in paguroids. With the exception of some lithodids, the paguroid cephalothorax is clearly delineated into an anterior carapace (shield) separated from the posterior carapace by the cervical groove and linea transversalis (It) (Fig. 7a, b). In galatheoids, hippoids, and Lomis, the comparable anterior portion of the cephalothorax is termed the "anterior" carapace. The lateral portion of the carapace (Fig. 7c) that covers the gills (branchiostegite) is well defined in galatheoids, in some, but not all, paguroids, but is very poorly defined in some hippoids. We have considered only the degree of calcification of the portions of the carapace, not shape or spination.

2a - Anterior carapace. Calcification of the shield in paguroids varies among families and genera. In the Pylochelidae, the shield is usually very well calcified, as it is in coenobitids and diogenids such as Tisea, Paguropsis, and Cancellus. In the Parapaguridae, Probeebei, Tylaspis, and Bivalvopagurus all have well-calcified shields, whereas species of the other genera are frequently characterized as having areas of reduced calcification. Lithodids all have well-calcified anterior carapaces, while only a few genera of the Paguridae exhibit more than moderate calcification.

We have found only two other taxa among the remaining anomurans that show any reduction in calcification of the anterior carapace, Petrocheles and Gastroptychus, and in the case of the latter, this may be an artifact of preservation in the spec- 
imens we examined. Previous authors (e.g., Baba, 1988) make no mention of reduced calcification in species of this genus.

2b. - Posterior carapace. 'In contrast to the calcification of the shield or anterior carapace in most paguroids, very few exhibit complete calcification of the posterior carapace, except for lithodids. In the Paguridae, completion of calcification is seen only in Ostraconotus, and nearly complete in Labidochirus; all other genera have only areas of partial calcification, if at all. Among the Diogenidae, only Tisea, and among the Parapaguridae, only Probeebei and Tylaspis have completely calcified posterior carapaces. The posterior carapace is well calcified in Birgus; there is only partial calcification in Coenobita. Little, if any reduction in calcification is seen in the remaining anomuran groups.

2c. - Branchiostegites. Calcification of the branchiostegites, when it occurs in paguroids, is most commonly restricted to the outer pterygostomial plate region (optp) (Fig. 7b, c). Exceptions include Placetron Schalfeew, 1892 among the Hapalogastrinae lithodids and all of the Lithodinae genera, the coenobitid Birgus, and possibly the diogenid Tisea.

Some degree of decalcification has been observed in the posterior and/or ventral portions of the branchiostegites in the hippoids Lophomastix Benedict, 1904, Albunea Weber, 1795, and Blepharipoda, as well as in the porcellanids Petrolisthes and Euceramus, and in Lomis.

3. Abdomen. The three characters examined in this category pertain only to the general shape and orientation of the abdomen, delineation of the abdominal somites, and the extent to which these have changed from the primitive elongate, straight, well-calcified, six-segmented abdomen of Neoglyphea. Internal symmetry is not addressed, as it does not appear relevant to carcinization; however, asymmetry as it pertains to the abdominal appendages is considered in subsequent sections. Similarly, the abdominal positioning of organs, such as seen in paguroids other than lithodids, is not addressed in this analysis. Character 3c (abdominal tergites 1-5) embodies character 20, emphasized by Richter \& Scholtz (1994).

3a. - Abdominal orientation. An elongate, straight abdomen is characteristic of the paguroid family Pylochelidae, the pagurid genera Paguritta Melin, 1939, Discorsopagurus McLaughlin, 1974, Orthopagurus Stevens, 1927, Enneophyllus McLaughlin, 1997, Pylopagurus, Xylopagurus, and a few individual species of other pagurid genera, as well as the parapagurid genus Tsunogaipagurus; most are inhabitants of tubular structures, such as hollow pieces of wood, polychaete tubes, scaphopod shells, etc. Exclusive of the Lithodidae and the coenobitid Birgus, elongate, but twisted abdomens are found in the vast majority of paguroid genera, reflecting their practice of occupying spiraled gastropod shells. As can been seen in. Table II, a few non-lithodid paguroids have simply reduced abdomens; however, in these, while there may be a tendency to fold the sixth somite, uropods, and telson ventrally, the abdomen itself is not similarly flexed. In contrast, the lithodid abdomen and that of Birgus are not only reduced, but distinctly folded under the cephalothorax.

In all other anomurans, there is some degree of reduction and explicit folding of the abdomen. Among hippoids this is maximized in members of the Hippidae where the elongate telson is firmly pressed against the thorax. In the galatheoids, optimum flexure is seen in the porcellanids. $\mathrm{Lo}$ mis too has the abdomen folded under the cephalothorax.

3b. - Abdominal segmentation. Varying degrees of visible segmentation of the abdomen can be found among paguroid families and genera. In the Pylochelidae, all six somites are clearly defined as they are in the Coenobitidae. Only in the diogenid Tisea, the pagurids Solitariopagurus and Alainopagurus, and the parapagurid Probeebei can this presumed plesiomorphic condition be clearly observed. In certain other diogenids, e.g., Paguristes, in virtually all other parapagurids, and pagurids such as Porcellanopagurus, Ostraconotus, Pylopaguropsis, and Xylopagurus, six somites often can be distinguished as slight to appreciable integumental thickenings or at least 
identifiable transverse segmental bands of fibrils. Although five clearly delineated segments are common at least to lithodids of the Lithodinae, the first is usually unrecognizable as a distinct somite because of fusion.

Six well-defined abdominal somites are characteristic of the Hippoidea, Galatheoidea, and Lomis; however, there often is appreciable reduction in the size of the first somite.

3c. - Tergite calcification. Again, it is the Paguroidea that manifests dramatic calcification loss. As the data in Table II demonstrate, the primitive condition of strong tergal calcification is seen in members of the Pylochelidae, the coenobitid Birgus, the parapagurid Probeebei, and in some genera of the Lithodidae. According to Lemaitre (1995) the strong calcification of the sixth tergite seen in such pagurid genera as $X y$ lopagurus and Discorsopagurus is clearly an adaptation for tube closing. Partíal calcification is more common among species of the remaining parapagurid genera, the hapalogastrinid lithodids and the pagurids Solitariopagurus, Alainopagurus, and Porcellanopagurus. In the vast majority of diogenids and pagurids, the sixth tergite is weakly calcified, while the remainder are membranous.

In contrast, there is little or no substantive reduction of calcification in the first five abdominal tergites in the galatheoids, hippoids, or Lomis.

\section{Uropods. We have considered the morpholog-} ical structure of the uropods only in very general terms. For example, the primitive state, "foliaceous" refers to a biramous appendage in which the rami are broad, flattened, and marginally setose, in contrast to more specialized appendages that are either symmetrical or asymmetrical. In paguroids this specialization takes the form of rasps of corneous spines or scales. Contrary to the rather sweeping statement made by Martin \& Abele (1986), lithodids are not the only paguroids to lack uropodal rasps. For example, although the uropods of the diogenid Paguropsis are, in structure, typical of other genera in the family, no rasps are present. Uropods are present but they are very greatly reduced in Birgus.

The uropods of hippoids are specialized for burrowing, but are not provided with rasps, whereas all galatheoids retain plesiomorphic foliaceous uropods. The uropods of females of $\mathrm{Lo}$ mis similarly are foliaceous, while those of the males are vestigial.

5. Female pleopods. We have divided the development of female pleopods into four separate characters, as considerable diversity occurs in the Paguroidea. Pleopods on the first abdominal somite of females in the Anomura occur only in the adult, and commonly are referred to as gonopods, although no sexually related function has ever clearly been demonstrated for them. Second pleopods, although usually unpaired, are symmetrically or asymmetrically paired in some taxa, or rarely are absent entirely.

Throughout the anomuran genera we examined, the third and fourth pleopods were present, either as paired or unpaired appendages, specifically adapted for egg carrying. Development of fifth pleopods was variable.

5a. - First pleopods. In Neoglyphea inopinata the paired first pleopods of the female are twosegmented, moderately long appendages. The distal segment is flattened, flagelliform, with the distal portion more or less divided into distinct articles. According to Forest \& De Saint Laurent (1989), these appendages are provided with a relatively precise arrangement of simple, plumose and barbed setae. Paired first pleopods are reported for all genera of the Pylochelidae; those of Mixtopagurus showing annulations (Forest, 1987: (fig. 75e) reminiscent of $N$. inopinata. Within the Diogenidae, only in the genera Paguropsis and Paguristes is the development of female first pleopods retained, although this condition has been lost in some species of the latter genus. When present, these paired first pleopods are commonly provided with marginal simple or plumose setae, but appear to lack the complexity seen in $N$. inopinata or the Pylochelidae. Among the Paguridae, paired first pleopods are developed in several genera, including Nematopagurus and all of the Pylopagurus-like genera (cf. McLaughlin, 1981). However, among those genera considered potential candidates for a paguroid carcinization pathway, only in Alainopaguroides are paired first 
pleopods developed. Paired first pleopods are lacking in all coenobitids.

Lomis was the only non-paguroid anomuran in which we found paired first pleopods developed, but these are rudimentary.

5b. - Second pleopods. Among paguroids, females of all pylochelids and parapagurids of the genera Parapagurus and Bivalvopagurus have paired pleopods on the second abdominal somite; their occurrence is variable in species of Sympagurus (sensu Lemaitre, 1989) and the right second is well developed or rudimentary in Tylaspis. Unpaired second pleopods can occur on either the right or left side of the abdomen in the diogenid genera Paguropsis and Cancellus, but are restricted to the left side in the remaining diogenid genera, coenobitids, and all of the pagurid and lithodid genera.

Female second pleopods are paired in hippoids, many of the galatheoids, and Lomis. They are absent in all porcellanids and some chirostylids, and reduced in some species of Munida and Galathea.

5c. - Third and fourth pleopods. Female paguroid third and fourth pleopods are paired in the Pylochelidae and the parapagurids Bivalvopagurus and Tylaspis, although they become rudimentary with increasing animal size (Lemaitre, in press). In all other paguroids, including the lithodids, unpaired pleopods occur on the left side only, except in the diogenid genera Paguropsis and Cancellus, where unpaired pleopods can occur on either side of the body.

Paired third and fourth pleopods occurred in all hippoids and galatheoids we examined, as well as in Lomis.

5d. - Fifth pleopods. As with the third and fourth pleopods, we found paired female fifth pleopods only in the paguroid family Pylochelidae and the parapagurids Bivalvopagurus and Tylaspis. Unpaired fifth pleopods occur on either the right or the left side in species of the diogenid genus Cancellus, but on the left side only in all other diogenid genera except Paguropsis, where they are absent. Loss of the fifth pleopod is universal in the coenobitids, and not uncommon in the Paguridae, being observed in Solitariopagurus, Alainopagurus, Porcellanopagurus,
Ostraconotus, Alainopaguroides, Lithopagurus, and Xylopagurus. Unpaired left fifth pleopods were present in all of the lithodids we examined.

Fifth pleopods are absent in females of Hippa Fabricius, 1787, but present in other hippoids. Lomis and most galatheoids have paired fifth pleopods, although we found them lacking in Uroptychus pubescens Faxon, 1893.

6. Posterior abdominal appendages of males. The occurrence, in males, of paired or unpaired pleopods developed on the third through fifth abdominal somites is variable, but when present, these appendages are not modified as gonopods. We have considered pleopod development on the third and fourth somites separately from the fifth.

6a. - Third and fourth pleopods. Only male paguroids of the Pylochelidae and the parapagurids Bivalvopagurus and Tylaspis have paired third and fourth-pleopods. These are symmetrical in the pylochelids, but strongly asymmetrical in the parapagurids. Unpaired left third and fourth pleopods are the rule for the other genera of the Parapaguridae, except Probeebei where they are vestigial or absent. These are lacking in Birgus, and reduced or absent in coenobitids. Similarly, pleopods are completely lacking in the diogenid genera Paguropsis and Cancellus, unknown for Tisea, but unpaired on the left in the remaining genera. Loss of third and fourth pleopods is characteristic of all lithodids and several pagurid genera and at least one species of Pagurus (see Table II).

6b. - Fifth pleopods. Among male paguroids, paired fifth pleopods are found only in the Pylochelidae and the parapagurids Bivalvopagurus and Tylaspis. Most commonly an unpaired left appendage is present, often somewhat smaller in size than the preceding two. In genera such as Porcellanopagurus, Solitariopagurus, etc., where the third and fourth pleopods are absent, the fifth also is missing; however, this pleopod is occasionally missing in pagurids that retain the third and fourth. The fifth, like the fourth and third, are absent in all lithodids. The fifth is always absent in coenobitids.

Pleopod reduction and/or loss is common in male hippoids, porcellanids, and numerous other galatheoids. They are vestigial in Lomis. 
7. Union of pterygostomial region of the carapace with the epistome (not included in Tables I and II). Such complete fusion is rarely, if ever, approached in anomuran taxa.

8. Adherence of the branchiostegites to the thoracic epimeres (not included in Tables I and II). Again, rarely approached in anomurans.

9. Branchia. We have used arthrobranch and pleurobranch formulae as they have been reported for various anomuran taxa as separate characters, but have not included epipods since their occurrence is restricted to some galatheoids and pylochelids. Gill type is the third character considered.

9a. - Arthrobranchia. Nearly all paguroids are provided with five pairs of arthrobranchs on each side of the body, one pair on the arthrodial membrane of the third maxillipede and one on each of the first four thoracic appendages. There are, however, three genera of the Paguridae in which loss of arthrobranchs has occurred, Enneobranchus García Gómez, 1988, Enneopagurus, and Enneophyllus. Five pairs of arthrobranchs are present in Birgus and Coenobita, but those of the third maxillipede and chelipedes are rudimentary and presumably non-functional in species of the latter genus.

Five pairs of arthrobranchs on each side of the body is also characteristic of all the hippoids and galatheoids examined, as well as Lomis.

9b. - Pleurobranchia. The primitive pleurobranch condition is represented by a single gill on the body wall between the arthrobranchs of pereiopods two through five. Among paguroids, this condition is seen in the Pylochelidae, Birgus, and several genera of the Diogenidae. Generally, when gill loss occurs, it is loss of the pleurobranchs, beginning with those of the second and third pereiopods. Most parapagurids have lost all but the pleurobranch of the fourth pereiopod; however, some species of Sympagurus (sensu Lemaitre, 1989) retain a remnant of a gill on the fifth pereiopod as well. Only in some genera of the Paguridae are pleurobranchs lost entirely.

Pleurobranch loss in the hippoids is variable, whereas Lomis and all of the galatheoids we examined retain a full complement of pleurobranchs.

9c. - Gill structure. Although dendrobranchiate gills are considered to reflect the primitive condition, these are thought to have given rise to the trichobranch gills of reptants (Martin \& Abele, 1986). Therefore the primitive gill structure is trichobranchiate for our analysis, and this is the gill structure of Neoglyphea inopinata (Forest \& De Saint Laurent, 1981) and all pylochelids (Forest, 1987). Of the diogenid genera examined, intermediate gills were found in Paguropsis. Gills in species of Paguristes varied from trichobranchiate to phyllobranchiate, while the latter were common to Clibanarius and Tisea. Phyllobranchiate gills are typical of the coenobitids and the majority of pagurid genera, however, there are genera whose species have either trichobranchiate or intermediate gill types. As far as we know, all lithodids have phyllobranchiate gills.

A few hippoids have trichobranchiate gills, others are phyllobranchiate, as are all galatheoids observed. The gills of Lomis are trichobranchiate.

10. Antennal scale (acicle/exopod). Reduction in the length and armature of the antennal acicle is considered evidence of carcinization; however, major reduction in the antennal acicle is observed in relatively few paguroids. It is shortened in Birgus and Coenobita, as well as in diogenid genera such as Cancellus and Clibanarius, and in pagurids such as Solitariopagurus, Porcellanopagurus, and Xylopagurus. Although spination, including aciclar development, is strongest in juvenile lithodids, the most significant reductions we observed were in adults of Paralithodes and Neolithodes.

Appreciable reduction in the antennal acicle was noted in some of the hippoid genera, the majority of galatheoids, and Lomis (Table II).

11. Presence of a sella turcica posterior (not included in Tables I and II). Although cited by Bourne (1922) as one of the characters of carcinization, a sella turcica is not present in all brachyurans and, to our knowledge has not been identified in any anomurans. 
12. Expansion of the ischia and meri of third maxillipedes to form a plate-like covering over the other mouthparts. There is considerable variation in the development of the endopod and exopod of third maxillipedes, as well as in setal types; however, only the expansion of the ischium and merus has been correlated to carcinization. We have added as a second character, the presence on the ischium of the tooth-like ridge referred to as the "crista dentata" and the occurrence of one or more "accessory teeth". Neoglyphea inopinata is provided with a prominent crista dentata and several accessory teeth (Forest \& De Saint Laurent, 1981), and we consider this condition to represent the plesiomorphic state, although this view is not shared by Scholtz \& Richter (1995).

12a. - Expansion of ischium and merus. No expansion of the ischium and merus of the third maxillipedes was observed in any of the paguroid genera examined.

Minor expansion of these segments was observed in Hippa, but only in the porcellanids was any noteworthy expansion seen.

12b.-Accessory tooth (teeth). Among the Pylochelidae, Mixtopagurus was the only one of three genera we observed that retained the accessory tooth; however, Forest (1987) noted its presence in Pomatocheles Miers, 1876 and reported two teeth in Trizocheles Forest, 1987 and several in Cancellocheles Forest, 1987. We know of no coenobitid, diogenid or parapagurid genus in which the crista dentata is provided with an accessory tooth, although the cristate structure itself is usually well developed. In the Paguridae, the situation is different. Richter \& Scholtz (1994) were unsure whether one or more teeth should be considered plesiomorphic or apomorphic, whereas we have rated its occurrence a plesiomorphic character. While species of the majority of pagurid genera have a well-developed crista dentata and one or more accessory teeth, in a few (e.g., Ostraconotus, Enneopagurus, Iridopagurus De Saint Laurent-Dechancé, 1966, and Decaphyllus De Saint Laurent, 1968) the accessory tooth is absent. Additionally, in a few genera the crista dentata itself is reduced, occasionally to only one or two teeth. The lithodid Placetron has no accessory tooth on the crista dentata.

In hippoids we found the crista dentata present, but lacking an accessory tooth in Lophomastrix and Blepharipoda; it is totally absent in the examined species of Hippa and Albunea. Among the Galatheoidea we reviewed, the primitive state was observed only in Aegla. The crista dentata was absent in all porcellanids and in at least one species of Uroptychus; it was present, but lacking an accessory tooth in Gastroptychus, Galathea, Munida, and Munidopsis. Lomis also has a crista dentata, but no accessory tooth.

13. Ocular orbit development with accompanying reduction in size of the antennules and antennae.

13a. - Ocular orbits. Development of ocular orbits in paguroids, if such occurs, is very slight, and limited to a-few lithodid taxa (Table II).

Among the other anomurans, only the Galatheoidea have weakly or well-developed ocular orbits, most specifically in some species of the Porcellanidae.

13b. - Antennular and antennal reduction. No appreciable reduction in antennular or antennal size was observed in any paguroid. However, in Birgus and Coenobita the antennules are strongly modified to function in the aerial environment.

Reduction in size, and number of segments, particularly in the antenna, was indicated only in galatheoids, notably in porcellanids.

14. Fusion of last thoracic somite. Poore (1994) rated Neoglyphea apomorphic in the fusion of the last thoracic somite, as in this taxon it is not fused to the seventh thoracic somite as it is in two of his other out-groups, Enoplometopus A. Milne Edwards, 1862 (sometimes considered an axiid) and Nephropsis stewarti Wood-Mason, 1873 (a nephropid lobster). Since there is neither fusion between the seventh and eight thoracic sterna in Neoglyphea nor in many of the Anomura, a lack of fusion is considered, for this analysis, the plesiomorphic state.

No fusion of the last thoracic somite was apparent in pylochelids, coenobitids, or diogenids. In parapagurids there appeared to be a tendency 
toward sternal fusion of the last thoracic and the first abdominal somites in species of most genera, including Sympagurus dimorphus Studer, 1883, a species scored by Richter \& Scholtz (1994) as not fused. Although fusion between the sternites of the last thoracic and first abdominal somites is common among pagurids, it is not complete in some genera, e.g., Labidochirus, Phimochirus McLaughlin, 1981, and Xylopagurus. In the lithodid genus Cryptolithodes there appears to be fusion of the last thoracic somite with both the first abdominal and the preceding thoracic somites.

No fusion of these somites was observed in any of the hippoids, galatheoids, or Lomis.

15. Position of dactyls of chelipedes. The brachyuran position of the dactyls perhaps has phylogenetic significance; however, this character presumes a chelate appendage. In $N$. inopinata the first pereiopods have simple dactyls. Some of the hippids have subchelate first pereiopods. In paguroids, all first pereiopods are chelate, although the manner in which they are carried may vary within any given genus. It is doubtful that in the Anomura this character contributes to any meaningful evaluation of the carcinization hypothesis.

16. Females with a receptaculum seminis (not included in Tables I and II). No female anomurans that we know of have a receptacle for sperm storage.

17. Development of first two pairs of pleopods in males. The presence, in $N$. inopinata, of paired first male pleopods specialized as gonopods is taken to indicate the plesiomorphic condition. Reduction and/or loss of one or both members of the pair is apomorphic. Paired, but natatory second pleopods are found in $N$. inopinata (Forest \& De Saint Laurent, 1981). The specialization of these pleopods followed by reduction and ultimate loss are considered apomorphic states. Our view of polarity in these male pleopods is contradictory to the interpretation of Martin \& Abele (1986).

17a. - First pleopods. Paired male first pleo- pods modified as gonopods are present in all pylochelids (Forest, 1987), in the diogenid genera Paguropsis and Paguristes, and in most parapagurids. The occurrence of paired first pleopods in the Paguridae is rare (e.g., Lithopagurus, $X \boldsymbol{X y}$ lopagurus), and has not been reported for any lithodid or coenobitid.

Among the other anomurans, paired copulatory first pleopods occur in some galatheoids and $\mathrm{Lo}$ mis (Table II).

$17 \mathrm{~b}$. - Second pleopods. No natatory male second pleopods are known in anomurans. In the pylochelids and some parapagurids, these appendages are modified as gonopods, as they are in Paguropsis, Paguristes, and Strigopagurus Forest, 1995, but unpaired and unmodified in coenobitids. With few exceptions, second pleopods of pagurids occur only on the left side of the abdomen, if they are present at all. Although second pleopods are reportedly absent in all lithodids, we have found a vestigial left appendage in Rhinolithodes.

Second pleopods are absent in hippoids. Among galatheoids, only in Aegla is the second pair reduced or absent (Martin \& Abele, 1988). Lomis also has paired second pleopods modified as gonopods.

18. Development of male penes. No development of penes is reported for Neoglyphea; therefore we consider the presence of paired, unmodified gonopores (lacking extensions of the vas deferens) the primitive condition.

Sexual tubes arising from the gonopores as extension of the vas deferens are reported in a number of paguroid genera, members of the Hippoidea, and in the galatheoid Aegla (Table II). On the basis of sexual tube development in the Paguridae, we have rated the presence of distinct tufts of setae masking the gonopores as an intermediate condition, such as seen in Pagurixus. While no true sexual tubes are developed in Birgus, there are slight protrusions of the vas deferens from each gonopore in preserved specimens. At least in some species of Coenobita, the vas deferens is produced into a well-calcified sexual tube.

\section{Inhalant opening lies primarily before the}


base of the chelipede (not included in Tables I and II). A rare, and most probably analogous situation occurs in some anomurans.

\section{Calcification of tergites of abdominal somites} 2-5 (see 3c, not included in Tables I and II).

21. Fusion of basal segments of upper antennular flagellum (not included in Tables I and II). Richter \& Scholtz (1994) suggested that the basal articles (segments) of the outer antennular flagellum fuse in a characteristic manner in the Paguridae and Lithodidae. However, they examined only six species. They observed similar fusion in two of six diogenid species inspected. Although we made no specific effort to determine the degree of fusion in antennular articles in species of the numerous genera we examined, casual observation suggests that, while this character may be significant in some phylogenetic applications, it does not appear to be directly related to carcinization.

22. Displacement of antennular aesthetases (not included in Tables I and II). Richter \& Scholtz (1994) similarly proposed that the positioning of the rows of antennular aesthetascs might demonstrate a phylogenetic relationship among the Paguridae and Lithodidae. Here again, their sample size was too small to permit meaningful evaluation, but it is doubtful that this character has any direct application to the present study.

23. Development of the fourth pereiopod. Of the three characters considered, two require clarification, i.e., the ventrolateral margin of the propodus (23b) and the termination of the appendage (23c). The primitive condition seen in Neoglyphea is a simple ambulatory leg with an unarmed propodal ventral margin. However, even when the fourth pereiopod functions as an ambulatory leg, the propodal margin may be armed with spines or tubercles.

A simple fourth pereiopod indicates that the dactyl functions as a typical terminal leg segment, analogous to the condition seen in the more anterior ambulatory legs. As recommended by McLaughlin (1997) and Sandberg \& McLaughlin
(1997), a distinction is made between subchelate fourth pereiopods and semichelate fourth pereiopods. In the former, the pereiopod is developed as a prehensile structure by the folding back of the dactyl against the propodus (e.g., Fig. 12e, f). In the latter, the ventral margin of the propodus is produced beneath the dactyl to such an extent that flexion of the dactyl becomes much more akin to the action of a dactyl against a fixed finger of a chelate appendage (e.gs, Fig. 12i-k). A chelate fourth pereiopod has the propodus developed into a characteristic "fixed finger", with which the dactyl functions as a true chela.

23a. - Size and structure of third and fourth pereiopods. As in $N$. inopinata, the fourth pereiopod is elongate and structurally similar to the third pereiopod in lithodids, galatheoids, hippoids, and Lomis. The fourth pereiopod in all these taxa (Fig. 12a, c, d) functions as a walking leg, with a simple terminal dactyl, except in the hippoids (Fig. 12b) where it is specialized, like the third, for burrowing. In Birgus, the fourth pereiopod is approximately one-half length of the third, armed with scattered small spines or spinules, but not ambulatory. In all non-lithodid paguroids, the fourth pereiopod is reduced and differs substantially from the third (Fig. 12e-o).

23b. - Ventrolateral margin of propodus of fourth pereiopod. The ventrolateral margin of the propodus in lithodids and galatheoids may or may not be provided with row(s) of spines. This margin is also armed in Lomis, but typically unarmed in hippoids. In many, but not all non-lithodid paguroids, this propodal margin may be specialized to form a propodal rasp of one to several rows of corneous spines or scales, often extending onto the lateral face (Figs. 12h-k, 13a-e). However, it is unarmed in Birgus, in the diogenid Paguropsis, in the parapagurids Probeebei (Fig. 13f) and Tylaspis (Fig. 13g), and in the pagurid Ostraconotus (Fig. 12e). The rasp of Alainopaguroides consists of two or three small corneous scales or spines (Fig. 12g).

23c. - Fourth pereiopod termination. The fourth pereiopod terminates simply in all lithodids, galatheoids, hippoids, and Lomis. Martin \& Abele's (1986) general statement that in all her- 


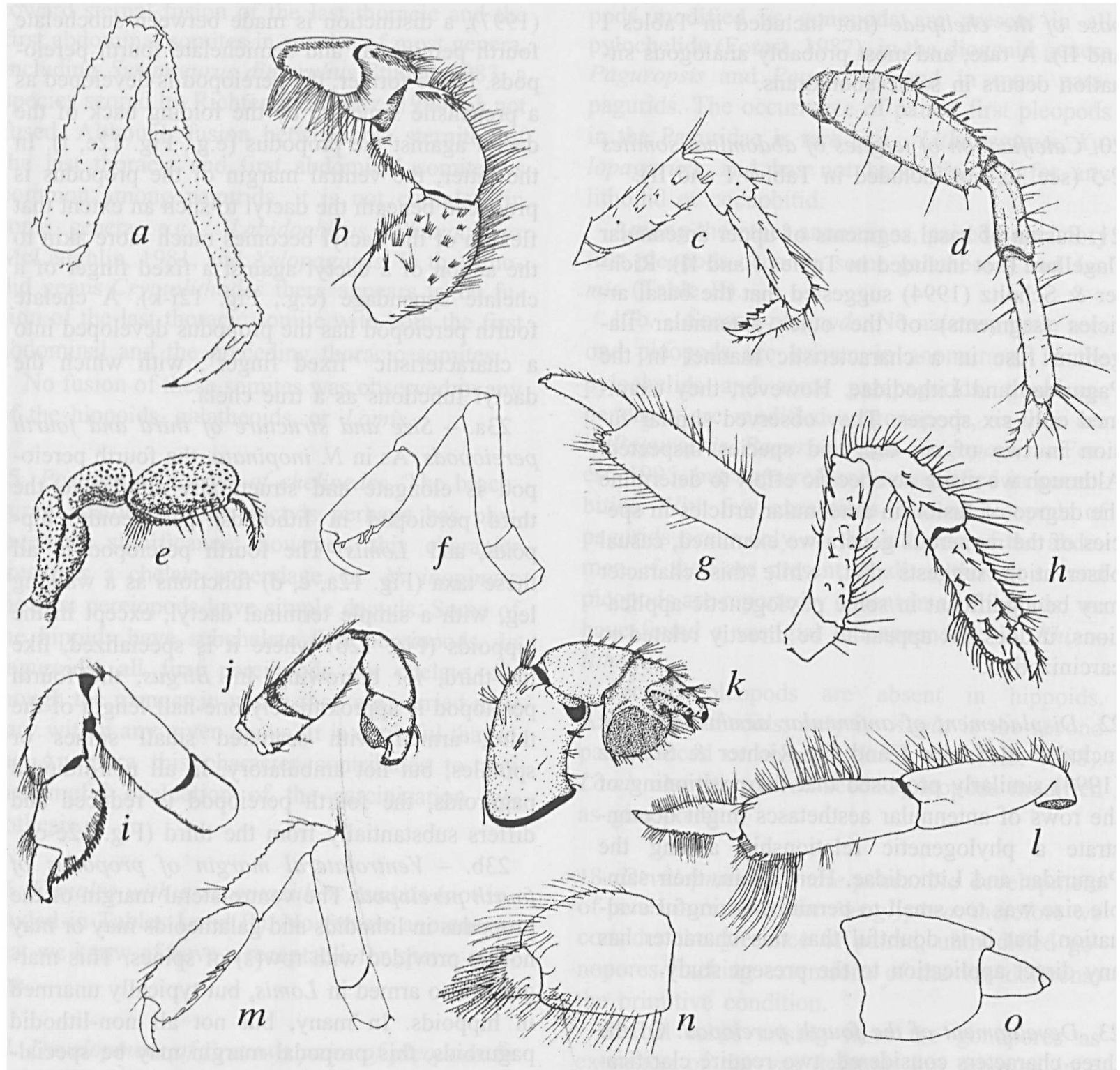

Fig. 12. Fourth pereiopods of various anomurans: a, Lithodes confundens Macpherson, 1988 (after Macpherson, 1988); b, Emerita talpoida (Say, 1817); c, Galathea consobrina De Man, 1902 (after Baba, 1988); d, Petrolisthes heterochrous Kropp, 1986 (after Kropp, 1986); e, Ostraconotus spatulipes A. Milne Edwards, 1880 (after A. Milne Edwards \& Bouvier, 1893); f, Solitariopagurus profundus Türkay, 1986 (after Türkay, 1986); g, Alainopaguroides lemaitrei McLaughlin, 1997, propodus and dactyl (after McLaughlin, 1997); h, Porcellanopagurus sp.; i, Tomopagurus wassi McLaughlin, 1981 (after McLaughlin, 1981); j, Pagurus trigonocheirus (Stimpson, 1858) (after McLaughlin, 1974); k, Xylopagurus tayrona Lemaitre \& Campos, 1993 (after Lemaitre \& Campos, 1993); 1, Munidopagurus macrocheles (A. Milne Edwards, 1880) (after Provenzano, 1971); m, Alainopagurus crosnieri Lemaitre \& McLaughlin, 1995 (after Lemaitre \& McLaughlin, 1995); n, o, Decaphyllus barunajaya McLaughlin, 1997, left (n) and right (o) propodus and dactyl (after McLaughlin, 1997). Not to scale.

mit crab families the fourth leg is subchelate, albeit barely so in some, is. not entirely accurate, even when the term semichelate is substituted for their "subchelate". Among non-lithodid pagu- roids, it is also simple in the pagurid genera Munidopagurus A. Milne Edwards \& Bouvier, 1893 (Fig. ${ }^{12}$ 1), Alainopagurus (Fig. 12m), and Decaphyllus (Fig. 12n). It is truly subchelate in 


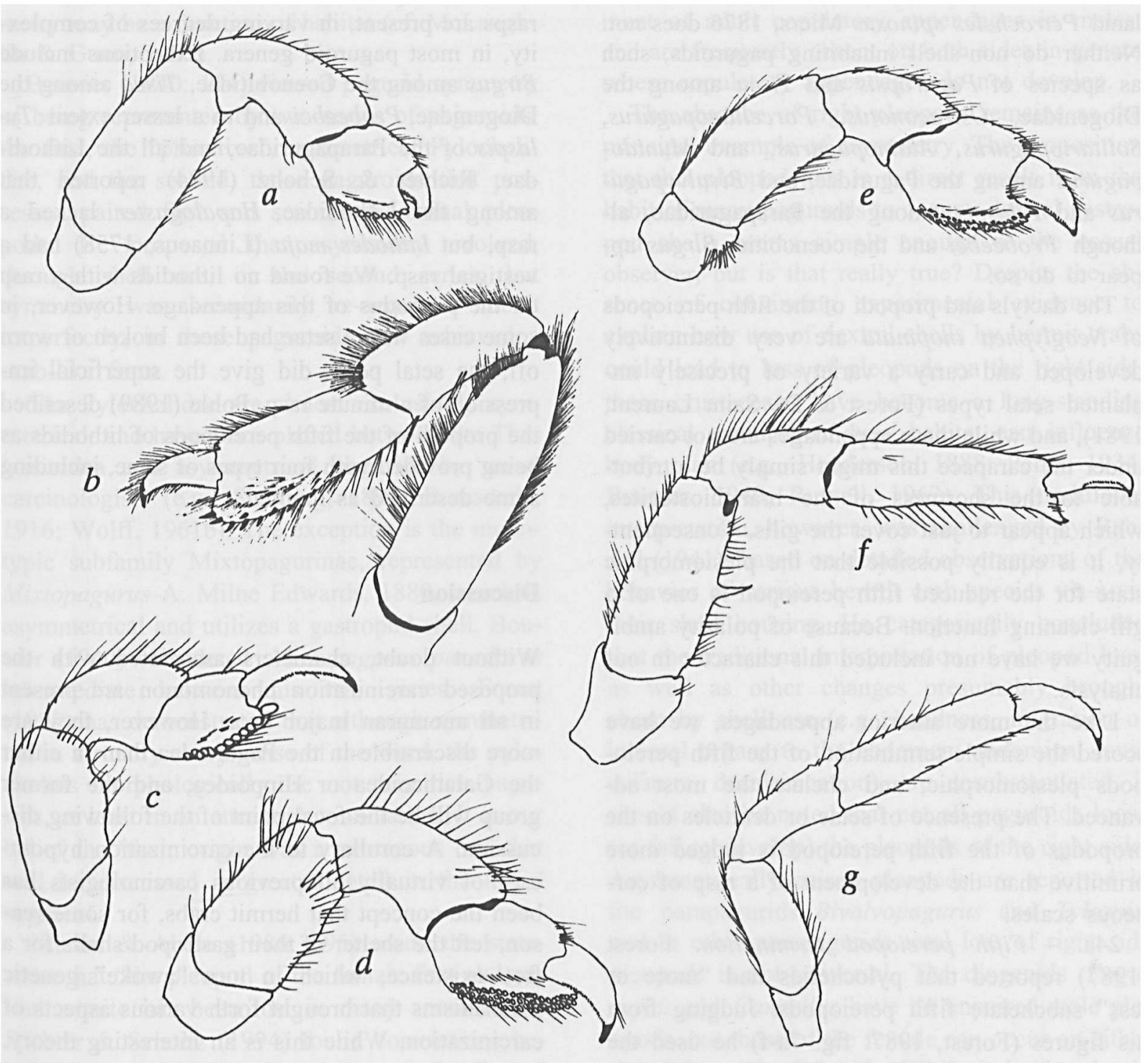

Fig. 13. Fourth pereiopods of Parapaguridae: a, Strobopagurus gracilipes (A. Milne Edwards, 1891); b, Sympagurus poupini Lemaitre, 1994 (after Lemaitre, 1994); c, Oncopagurus cidaris Lemaitre, 1996 (after Lemaitre, 1996); d, Sympagurus dimorphus (Studer, 1883); e, Parapagurus sp.; f, Probeebei mirabilis Boone, 1926b; g, Tylaspis anomala Henderson, 1888 (after Lemaitre, in press). Not to scale.

Solitariopagurus (Fig. 12f), and chelate in Birgus and the diogenid Paguropsis.

24. Position and structure of the fifth pereiopod. A character that unites the Anomura as a monophyletic entity is the reduction of the fifth pereiopod, and presumably its position in the branchial chamber for gill cleaning (Scholtz \& Richter, 1995). The exception, according to these authors, is found only in shell-dwelling paguroids. There is unquestionably a significant reduction in fifth leg size in all anomurans, but that all non-shell inhabiting anomurans carry the fifth legs within the branchial chamber is not as universal as these authors suggest. Among the small sample of galatheoids we examined, it is questionable whether Galathea rostrata A. Milne Edwards, 1880 actually carries the fifth leg in the branchial chamber; species of Uroptychus and Chirostylus probably do not, and it is certain that the porcel- 
lanid Petrocheles spinosus Miers, 1876 does not. Neither do non-shell inhabiting paguroids, such as species of Paguropsis and Tisea among the Diogenidae, Ostraconotus, Porcellanopagurus, Solitariopagurus, Alainopagurus, and Munidopagurus among the Paguridae, and Bivvalvopagurus and Tylaspis among the Parapaguridae, although Probeebei and the coenobitid Birgus appear to do so.

The dactyls and propodi of the fifth pereiopods of Neoglyphea inopinata are very distinctively developed and carry a variety of precisely implanted setal types (Forest \& De Saint Laurent, 1981), and while these appendages are not carried under the carapace this might simply be attributable to the shortness of the branchiostegites, which appear to just cover the gills. Consequent$\mathrm{ly}$, it is equally possible that the plesiomorphic state for the reduced fifth pereiopod is one of a gill cleaning function. Because of polarity ambiguity we have not included this character in our analysis.

Like the more anterior appendages, we have scored the simple termination of the fifth pereiopods plesiomorphic, and chelate the most advanced. The presence of setae or denticles on the propodus of the fifth pereiopod is judged more primitive than the development of a rasp of corneous scales.

24a. - Fifth pereiopod termination. Forest (1987) reported that pylochelids had "more or less" subchelate fifth pereiopods. Judging from his figures (Forest, 1987: fig. 7a-f) he used the term subchelate to reflect both truly subchelate and semichelate conditions. He did not figure this appendage for Cheiroplatea, which we score as tending toward a chelate condition. Chelate fifth pereiopods were found in all of the diogenid genera we examined, whereas in some parapagurids this appendage terminated in a semichelate structure. Among pagurid genera, the fifth pereiopod is subchelate in Solitariopagurus and Alainopagurus, semichelate in Porcellanopagurus and nearly so in Alainopaguroides, and chelate or nearly so in the other genera and species examined (Table II). In all other anomurans investigated it is chelate.

24b. - Propodus of fifth pereiopod. Propodal rasps are present, in varying degrees of complexity, in most paguroid genera. Exceptions include Birgus among the Coenobitidae, Tisea among the Diogenidae, Probeebei and to a lesser extent $T y$ laspis of the Parapaguridae, and all the Lithodidae. Richter \& Scholtz (1994) reported that among the Lithodidae, Hapalogaster lacked a rasp, but Lithodes maja (Linnaeus, 1758) had a vestigial rasp. We found no lithodids with a rasp on the propodus of this appendage. However, in some cases where setae had been broken or worn off, the setal pores did give the superficial impression of a minute rasp. Pohle (1989) described the propodi of the fifth pereiopods of lithodids as being provided with four types of setae, including some described as toothed.

\section{Discussion}

Without doubt, characters associated with the proposed carcinization phenomonon are present in all anomuran major taxa. However, they are more discernible in the Paguroidea than in either the Galatheoidea or Hippoidea, and the former group will be the focal point of the following discussion. A corollary to the carcinization hypotheses of virtually all previous carcinologists has been the concept that hermit crabs, for some reason, left the shelter of their gastropod shells for a free existence, which in turn "awoke" genetic mechanisms that brought forth various aspects of carcinization. While this is an interesting theory, it is founded on the premise that those crabs that underwent carcinization evolved from hermits that were first and foremost asymmetrical animals that inhabited gastropod shells.

The question of asymmetry has not been introduced to this point in our consideration of characters of carcinization, except in relation to pleopod loss. Paguroid asymmetry, in its most observable forms, is seen in unequal chelipedes, unequal specialized uropods, and the absence of pleopods on the right side of the body. Nonetheless, a substantial number of paguroid genera have equal or nearly equal chelipedes. Numerous genera also have equal, and in a few cases, completely unmodified uropods. In other genera, uropod asym- 
metry may be a function of habitat (cf. McLaughlin \& Gunn, 1992).

Bouvier (1940: 114)'viewed pagurid symmetry as being represented by two series of paguroids: the first, the "primitive", symmetrical Pylochelidae, and the second, those paguroids that possessed paired first and second abdominal pleopods. He proposed that asymmetry evolved, through shell use, in the second series, but symmetry was secondarily re-acquired, albeit imperfectly, in those paguroids that achieved a crab-like form.

The Pylochelidae are almost exclusively symmetrical, and have been placed between the Thalassinidea and asymmetrical pagurids by many carcinologists (e.g., Stebbing, 1893; Borradaile, 1916; Wolff, 1961b). The exception is the monotypic subfamily Mixtopagurinae, represented by Mixtopagurus A. Milne Edwards, 1880, which is asymmetrical and utilizes a gastropod shell. Bouvier (1940) considered Mixtopagurus paradoxus intermediate between his two series. Forest (1987) has demonstrated that although symmetrical in virtually every sense of the word, the pylochelids morphologically are not primitive pagurids, at least in an ancestral connotation. It is our belief that their origin was a neotenous one that will be discussed in greater detail in the larval segment.

Martin \& Abele (1986: 595) made the statement that "the pleopod of the female first abdominal somite has been lost in many anomurans". Richter \& Scholtz (1994) found correlations between an asymmetrical abdomen and pleopod loss, but considered "the situation regarding the 1st and 2nd pleopods more complex". It is of primary importance to point out that in the Anomura, pleopods do not occur on the first abdominal somite in either sex unless they arise in the maturing adult as sexually modified appendages. The concept that paired first pleopods are lost through shell use is incorrect. These gonopods are never developed in either sex in many genera, including several non-shell dwelling paguroids, e.g., Solitariopagurus, Alainopagurus, Porcellanopagurus, and Ostraconotus. Similarly, paired second pleopods, present in megalopae, are usually reduced or lost prior to the develop- ment of adult copulatory appendages in males, and are frequently absent on both sides in genera where copulatory appendages do not develop.

The absence of right pleopods remains as the principal example of asymmetry. The proposition that this pleopod loss is a direct result from the habit of many paguroids to occupy dextral gastropod shells seems simple enough to the casual observer, but is that really true? Despite the absence of convincing experimental evidence to explain how use of dextral shells by hermit crabs could lead to loss of pleopods on the right side, these crustaceans have become a long-standing classical example of how habitat can influence body plan (e.g., Henderson, 1888; Pérez, 1934; Bouvier, 1940; Russell, 1962). This traditional interpretation, however, was challenged by Rabaud (1941), based on detailed observations of the behavior of various hermit crab species vis-à-vis their shell housing. He categorically concluded that the traditional interpretation of pleopod loss, as well as other changes presumably brought about by shell use (e.g., handness, migration of internal organs to the abdomen, abdominal musculature, decalcification), are unsubstantiated. It should also be noted that not all paguroids loose (or fail to develop) the pleopods of the right side. Asymmetrically paired pleopods are reported in the parapagurids Bivalvopagurus and Tylaspis, and in other parapagurids total loss of right side pleopods is not universal. The diogenids Paguropsis and Cancellus have no unpaired male pleopods, but those of the female can occur on either the right or the left side. While it is abundantly clear that we still can not adequately explain the overwhelmingly more frequent occurrence of unpaired left pleopods, it is equally clear that what might appear to be the obvious explanation might not be the accurate one. For example, Sandberg \& McLaughlin (1997) report that pleopods are completely absent in very juvenile Lithodes maja, and development of pleopods on the left side in females is preceded by slight asymmetry of the abdomen; female gonopods develop considerably later. These authors suggest that abdominal asymmetry and asymmetrical pleopod development may simply be a function of egg bearing. Given the fact that male lithodids have symmetrical ab- 
Table II. List of taxa (59) and characters (37) used in the analysis. Numerals are the same as for characters in Table I and text (see Characters and/ or character states). Character states: 0-7; missing data: "?". Numbers separated by dash indicate multiple character states.

\begin{tabular}{|c|c|c|c|c|c|c|c|c|c|c|c|c|c|c|c|c|c|c|c|c|}
\hline Neopypher unopiats & $\mathbf{u}$ & $\mathbf{v}$ & v & v & u & $\mathbf{v}$ & v & v & v & $\mathbf{u}$ & $\mathbf{v}$ & v & v & u & $\mathbf{u}$ & v & $\mathbf{u}$ & u & & $\mathbf{v}$ \\
\hline Coenobitu & 2 & 3 & 23 & 0 & 0 & 1 & 0 & 1. & 1 & 1 & 0 & 1 & 2 & 3 & 2 & 2 & 3 & 34 & & 4 \\
\hline Birgua & 23 & $1-2$ & 0 & 0 & 0 & 1 & 0 & 0 & 0 & 3 & 0 & 0 & $1-2-3$ & 3 & 2 & 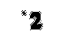 & 3 & 4 & & 4 \\
\hline Pylocheles: & $0-1$ & 3 & 2 & 0 & 0 & 0 & 0 & 1 & 1 & 3 & 0 & 0 & 1 & 0 & 0 & 0 & 0 & 0 & & 0 \\
\hline Cheiroplatea & $0-1$ & 3 & 1 & 0 & 0 & 0 & $0-1$ & 1 & 1 & 3 & 0 & 0 & 1 & 0 & 0 & 0 & 0 & 0 & & 0 \\
\hline Mixtopagurua & 23 & 3 & 1 & 0 & 0 & 0 & 0 & 1 & 1 & 0 & 0 & 0 & $1-2$ & 0 & 0 & 0 & 0 & 0 & & 0 \\
\hline Peguropela & 2 & 2 & 1 & 0 & 0 & 1 & 0 & 1 & 2 & 2 & 2 & 2 & $0-1$ & 0 & 1 & 1 & 3 & 4 & & 4 \\
\hline Pequrbates & 3 & 23 & 1 & 0 & 0 & 02 & 04 & 1 & 1 & 1 & 1 & 2 & 2 & 0 & 2 & 2 & 2 & 2 & & 2 \\
\hline Coneellow & 01 & 3 & 0 & 0 & 0 & 0 & 0 & 1 & 1 & 0 & 3 & $1-2$ & 1 & 3 & 1 & 1 & 1 & 4 & 4 & 4 \\
\hline Cllbunarius & 3 & 3 & 1 & 0 & 1 & $1-2$ & 1 & 2 & 2 & 1 & 2 & 2 & 2 & 3 & 2 & 2 & 2 & 2 & & 2 \\
\hline Tinen & 1 & $2-3$ & 1 & 0 & $?$ & 7 & 0 & 0 & 1 & 1 & 0 & 1 & 2 & 3 & 2 & 2 & 2 & 7 & & 1 \\
\hline Probeebel & $1-2$ & 0 & 0 & 1 & 1 & $0-1$ & 0 & 0 & 1 & 3 & 0 & 0 & $1-2$ & 3 & 2 & 2 & 2 & 34 & 34 & \\
\hline Tylapis & 12 & 2 & 0 & 1 & 1 & 1 & $0-1$ & $0-1$ & 1 & 2 & 1 & 1 & 1 & 3 & 0 & 0 & 0 & 0 & 0 & 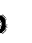 \\
\hline Sympagurus: & 1 & 3 & 1 & 1 & 0 & 1 & $1-2$ & 1 & 1 & $0-1$ & 1 & $1-2$ & $1-2$ & 3 & $0-2$ & 2 & 2 & 2 & & 2 \\
\hline Parapaguru: & 1 & 3 & 1 & 1 & 0 & $\mathbf{1}$ & 02 & 1 & 1 & 1 & 1 & $1-2$ & 2 & 3 & 0 & 2 & 2 & 2 & & 2 \\
\hline Bivalvopaguru: & 1 & 2 & 2 & 1 & 0 & 1 & 0 & 1 & 2 & 23 & 1 & 1 & 1 & 3 & 0 & 0 & 0 & 0 & & 0 \\
\hline Trunogalpagurus & 1 & 2 & 2 & 1 & 0 & 0 & $0-2$ & 1 & 1 & 0 & 1 & $1-2$ & 1 & 3 & 2 & 2 & 2 & 2 & & 2 \\
\hline Solltorlopaguras & 2 & $2 \times$ & 2 & 1 & 1 & 2 & 0 & 1 & 1 & 2 & 0 & $0-1$ & 1 & 3 & 2 & 2 & 3 & 4 & & 4 \\
\hline Alalnopagurut & 2 & 2 & 2 & 1 & 1 & 2 & 0 & 1 & 1 & 2 & 0 & $0-1$ & 1 & 3 & 2 & 2 & 3 & 4 & & 4 \\
\hline Porcellanopagurus & 2 & 2 & 2 & 1 & 1 & $1-2$ & 0 & 1 & 1 & 2 & 1 & $1-2$ & 1 & 3 & 2 & 2 & 3 & 4 & & 4 \\
\hline OAlraconotur & 1 & 2 & 3 & 1 & 1 & 2 & 0 & 0 & 1 & $2-3$ & 1 & 2 & 0 & 3 & 2 & 2 & 3 & 4 & & 4 \\
\hline Alalnopaguroides: & 1 & 3 & 1 & 1 & 1 & 2 & 1 & 1 & 1 & 2 & 2 & 2 & 1 & 0 & 2 & 2 & 3 & 4 & & 4 \\
\hline Ieelopagurux & 1 & 2 & 2 & 1 & 1 & $1-2$ & 1 & 2 & 2 & 1 & 2 & 2 & 2 & 3 & 2 & 2 & 2 & 2 & & 2 \\
\hline Pagurodea & 23 & 2 & $1-2$ & 1 & $0-1$ & 1 & 1 & 2 & 1 & 1 & $1-2$ & 2 & 2 & 3 & 2 & 2 & 2 & 2 & & 2 \\
\hline Mikhelopagurus & 3 & 3 & 1 & 1 & $: 1$ & 1 & 2 & 2 & 1 & 1 & 2 & 2 & 2 & 0 & 2 & 2 & 2 & 2 & & 2 \\
\hline Nemantopezuru: & 3 & 3 & 1 & 1 & 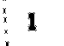 & 1 & 1 & 2 & 2 & 1 & 2 & 2 & 2 & 0 & 2 & 2 & 2 & 2 & & 2 \\
\hline Pslopigurus: & $0-1$ & 2 & 1 & 1 & $0-1$ & 1 & 1 & 2 & 1 & 0 & 1 & 2 & 1 & 0 & 2 & 2 & 2 & 2 & & 2 \\
\hline Enneopwguras & 23 & 23 & $1-2$ & 1 & 0 & 1 & 1 & 2 & 2 & 1 & 2 & 2 & 2 & 3 & 2 & $\mathbf{2}^{*}$ & 2 & 2 & & 2 \\
\hline Pylopueuropels & 3 & 2 & $\mathbf{1}$ & 1 & 0 & 1 & 1 & 2 & 2 & 1 & 2 & 2 & 2 & 0 & 2 & 2 & 2 & 2 & & 2 \\
\hline Xylopagurus & 0.3 & 2 & 1 & 1 & 0 & 0 & $0-1$ & 1 & 1 & 0 & 1 & 2 & 1 & 3 & 2 & 2 & 3 & 4 & & 4 \\
\hline Labidochlirm & 12 & $1-2$ & 1 & 1 & 1 & 1 & 1 & 01 & 2 & $1-2$ & 2 & 2 & 2 & 3 & 2 & 2 & 2 & 4 & & 34 \\
\hline Lthopagurew & 2 & $1-2$ & 1 & 1 & 1 & 1 & 1 & 2 & 2 & 2 & 2 & 2 & 1.2 & 3 & 2 & 2 & 3 & 4 & & 4 \\
\hline Polmoetlrus & 3 & 2 & 1 & 1 & 1 & 1 & 1 & 2 & 2 & 1 & 1 & 1 & 2 & 0 & 2 & 2 & 2 & 2 & & 2 \\
\hline Pegura bernbardas & 3 & 23 & $1-2$ & 1 & 1 & 1 & 2 & 2 & 12 & 1 & $1-2$ & 2 & $\mathbf{2}$ & 3 & 2 & 2 & 2 & 2 & & 2 \\
\hline Pagurus prideanx & 3 & 3 & 2 & 1 & $0-1$ & 1 & 1 & 2 & 1 & 1 & 2 & 2 & 2 & 3 & 2 & 2 & 2 & 4 & & 4 \\
\hline Hopalogeter & 1 & 0 & 3 & 1 & 1 & 2 & 0 & 0 & 1 & 23 & 2 & $1-2$ & 3 & 0.3 & 2 & 2 & 2 & 4 & & 4 \\
\hline Oedignethus & 1 & 2 & 2 & 1 & 1 & 2 & 0 & 0 & 1 & 23 & $1-2$ & $1-2$ & 3 & 0 & 2 & 2 & 2 & 4 & & 4 \\
\hline Placetron & 1 & 0 & 3 & 1 & 1 & 2 & 0 & 0 & 0 & 23 & $1-2$ & $0-2$ & 3 & 3 & 2 & 2 & 2 & 4 & & 4 \\
\hline Rhinolithodes & 2 & 2 & 1 & 1 & $1-2$ & 2 & 0 & 0 & 0 & 3 & 2 & 1 & 3 & 0 & 2 & 2 & 2 & 4 & & 4 \\
\hline Pordithodea & 2 & 0 & 2 & 1 & 1 & 2 & 0 & 0 & 0 & 3 & 2 & 0 & 3 & 0 & 2 & 2 & 2 & 4 & & 4 \\
\hline Litboder & 2 & 0 & 2 & 1 & 1 & 2 & 0 & 0 & 0 & 3 & 2 & 0 & 3 & 0 & 2 & 2 & 2 & 4 & & 4 \\
\hline Neollthode & $1-2$ & $0-1$ & 3 & 1 & 1 & 2 & 0 & 0 & 0 & 3 & $1-2$ & 0 & 3 & 0 & 2 & 2 & 2 & 4 & & 4 \\
\hline Paralowis: & 2 & 2 & 2 & 1 & 1 & 2 & 0 & 0 & 0 & 3 & 2 & 0 & 3 & 0 & 2 & 2 & 2 & 4 & & 4 \\
\hline Cryptollithoder & $1-2$ & 0 & 0 & 1 & 1 & 2 & 0 & 0 & 0 & 3 & 2 & 0 & 3 & 3 & 2 & 2 & 2 & 4 & & 4 \\
\hline Lomla & $1-2$ & 2 & 2 & 1 & 1 & $1-2$ & 0 & 0 & 0 & 3 & 0 & 0 & 0 & 0 & 0 & 0 & 0 & 0 & & 0 \\
\hline Ilppw & 0 & 3 & $0-1$ & 1 & 0 & 0 & 0 & 0 & 0 & 3 & 0 & 0 & $0-1$ & 3 & 0 & 0 & 3 & 4 & & 4 \\
\hline Lophominatrk & 0 & 2 & 2 & 1 & 0 & 0 & 0 & 0 & 1 & 3 & 0 & 0 & $0-1$ & 3 & 1 & 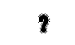 & 7 & 4 & & 4 \\
\hline Albuat & 12 & 2 & 2 & 1 & 0 & 0 & 0 & 0 & 1 & 3 & 0 & 0 & $\times 0-1$ & 3 & $0^{2}$ & 0 & 0 & 7 & & 7 \\
\hline Blepharipodn & $1-2$ & 2 & 2 & 1 & 0 & 1 & 0 & 0 & $0-1$ & 3 & 0 & 0 & $0-1$ & 3 & 0 & 0 & 0 & 4 & & 4 \\
\hline Aegla & 2 & 0 & $1-2$ & 1 & 1 & 2 & 0 & 0 & 0 & 3 & 0 & 0 & 0 & 3 & 0 & 0 & 0 & 34 & & 34 \\
\hline Bocernomuse & 0 & 2 & 2 & 1 & 2 & 2 & 0 & 0 & 1 & 3 & 0 & 0 & 0 & 3 & 3 & 0 & 0 & 4 & & 4 \\
\hline Petrollithes & 3 & 2 & 2 & 1 & 2 & 2 & 0 & 0 & 1 & 3 & 0 & 0 & 0 & 3 & 3 & 0 & 0 & $\times 4$ & & 4 \\
\hline Petrochelea & 3 & 2 & 0 & 1 & 2 & 2 & 1 & 0 & 0 & 3 & 0 & 0 & 0 & 3 & 3 & 0 & 0 & 4 & & 4 \\
\hline Poljonyx & 1 & 3 & 0 & 1 & 2 & 2 & 0 & 0 & 0 & 3 & 0 & 0 & 0 & 3 & 3 & 0 & 0 & 4 & & 4 \\
\hline Castroptychus & 1 & 1 & 1 & $0-1$ & 1 & $1-2$ & $1-2$ & $1-2$ & 0 & 3 & 0 & $0-1$ & 0 & 3 & 0 & 0 & 0 & 4 & & 4 \\
\hline Uroplychu & 2 & 0 & 2 & 1 & 2 & 2 & 0 & 0 & 0 & 3 & 0 & 0 & 0 & 3 & 3 & 0 & 3 & 3 & & 4 \\
\hline Galnthen & 12 & 0 & 1 & $0-1$ & $1-2$ & 2 & 0 & 0 & 0 & 3 & 0 & 0 & 0 & 3 & 0 & 0 & 0 & 0 & & 0 \\
\hline Mupoldn & 12 & 1 & 3 & 1 & 2 & 2 & 0 & 0 & 0 & 3 & 0 & ODo & looded & $\mathrm{fr} 3 \mathrm{~m}$ & Briol. & $\operatorname{com} \theta / 2$ & $26 / 2 @ 3$ & & & P \\
\hline Munidopals & 12 & 0 & 0.2 & 1 & $1-2$ & 2 & 0 & 0 & 0 & 3 & 0 & 0 & 0 & 3 & 0 & 0 & vio & free ${ }^{\text {ac }}$ & & 5 \\
\hline
\end{tabular}


Table $I$. Continued.

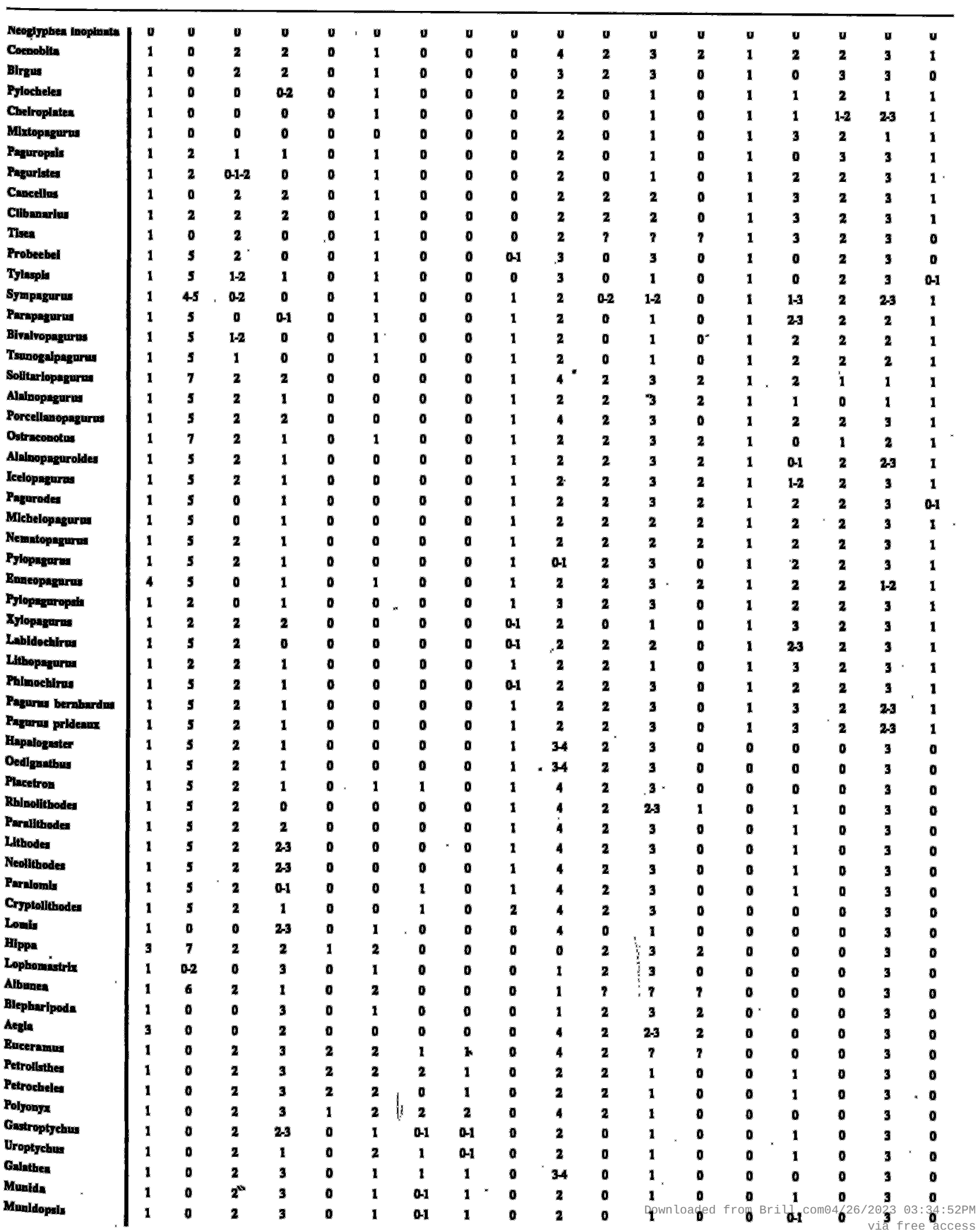


domens and no pleopods, their proposition may well have merit. As in lithodids, males of Porcellanopagurus, Ostraconotus, Alainopaguroides, Solitariopagurus, and Alainopagurus completely lack pleopods; those of the female develop as egg-bearing appendages on somites two through four, but only in Alainopaguroides are gonopods developed. Unfortunately, complete understanding of pleopod presence and/or absence in paguroids is dependent upon a knowledge of pleopod development in megalopae and juveniles. This will be discussed in greater detail during our subsequent presentation of larval evidence.

\section{Carapace shape and integumental calcification}

In terms of carapace shape and integumental calcification, the Lithodidae, and particularly the subfamily Lithodinae, are considered the most carcinized. Correspondingly, in these same characters they rank among the more plesiomorphic (Table II). If one examines a series of pagurid genera, a distinct pattern of calcification loss can be observed from the well-calcified Solitariopagurus, Porcellanopagurus, Ostraconotus, through the slightly less calcified Alainopagurus, Alainopaguroides, Pagurodes, and continuing through Labidochirus and Xylopagurus to eventually genera such as Michelopagurus McLaughlin, 1997. and Pagurus. The primary method by which the cuticular integument is hardened is through calcification in which calcium salts are deposited in the organic matrix of the cuticle (Stevenson, 1985). It is beyond the scope of this commentary to discuss calcification in any detail, and the reader is referred to the reviews by Stevenson (1985) and Goffinet \& Jeuniaux (1994) for specific information and references. Suffice it to say here that calcium needed for cuticular growth is supplied in part through diet (e.g., Lafon, 1948) or absorption from the ambient water (e.g., Miyazaki \& Jozuka, 1964). The diet of the lithodid Paralithodes camtschatica in the eastern Bering Sea consists of foods rich in calcium, i.e., mollusks and echinoderms (McLaughlin \& Hebard, 1960), whereas pagurids and diogenids, as far as known, are macrophagous and detritivore scavengers (e.g., Kunze \& Anderson, 1979; Schembri, 1982).
If one accepts the plesiomorphy of integumental calcification, it might be hypothesized that a lack of availability of calcium-rich foods was instrumental in triggering the onset of an evolutionary pattern of integumental decalcification.

\section{Abdominal modifications}

While a well-calcified abdomen with distinct tergal plates is a primitive character state, reduction and folding of the abdomen, on the contrary, is considered, in this review, an advanced condition. However, as well put by Glaessner (1957), an abdomen when not functioning as a swimming organ impedes normal mobility of benthic animals that possess a rigid carapace. It would seem that there might well be an advantage to a lithodid not to have to carry a large, heavily plated abdomen in a posteriorly extended position, particularly if its appendages were no longer available for locomotion. Studies of juvenile king crabs indicate that they initially are not free-roaming, but spend nearly their entire first year in rock crevices and other protective niches (Powell, 1974). It is quite reasonable to suspect that by tucking the abdomen beneath the body, thus exposing the calcified abdominal terga to the rough substrate, the crab would be less likely to sustain injury to its membraneous sternal region.

Although folding of the abdomen beneath the cephalothorax is an apomorphic character, the development of the elongate abdomen of a typical pagurid is not viewed here as an atavism. Consider the event of a potential calcium loss discussed above, followed from the Lithodinae through the Hapalogastrinae, via the first eight pagurid genera cited in the section on carapace shape and integumental calcification, to the typical pagurid with an entirely membranous abdomen virtually devoid of segmentation. Concurrent with the loss of calcified plates would be increased absorption of fluids to maintain body turgor, as is seen in the bulbous abdomens of species of the Hapalogastrinae, and Porcellanopagurus, Alainopagurus, etc., among the pagurids. The elongation of the abdomen then well might be justifiably be considered an adaptation to shellliving. That this paguroid abdomen is not a phy- 
logenetic reappearance of the elongate abdomens of other reptants is demonstrated by the fact that in paguroids (except lithodids) the reproductive organs and elements of the hepatopancreas are located there, a condition not found in other decapods (McLaughlin, 1980).

\section{Fourth and fifth pereiopods}

All anomurans have reduced fifth pereiopods that may, or may not be carried under the carapace. However, among paguroids, only the lithodids have retained the fourth pereiopod as a walking leg. The presence of this primitive character was considered an atavism by Boas (1924), and possibly an example of a posterior shift in genetic information for size and spine pattern of anterior leg by Richter \& Scholtz (1994). Supportive evidence for the latter claim may have inadvertently come from McLaughlin (1983b) who cited Harms $(1932,1938)$ and Wolff $(1961 b)$ when she reported, sight unseen, that "Birgus abandons its shell shelter, undergoes a moderate degree of carcinization, and takes up a free-living existence. With these changes the fourth pereiopods grow and take on an ambulatory function". Now having personally examined Birgus, we can report that its chelate fourth pereiopods cannot be equated to the ambulatory fourth legs of the lithodids, but rather represent a specialization for its terrestrial life-style.

The fourth pereiopods in Probeebei and Tylaspis are unquestionably reduced, and when compared with the exceptionally elongate second and third pereiopods, seem markedly so. However, both are simple appendages without rasps on the propodi and with claw-like dactyls. A pattern of specialization can then be followed. The propodus of the fourth pereiopod in Ostraconotus is greatly expanded into a flattened, ovoid structure; the lateral face is covered with minute granules. The fourth pereiopods in Solitariopagurus show a hint of a propodal rasp in having three clubshaped and three spiniform stiff bristles on the ventral surface. Alainopaguroides has only two or three small scales, while Alainopagurus has a row of small, simple spines. Further modification is seen in Porcellanopagurus where the ventrolater- al margin has a row of corneous scales. The propodal rasps of the fourth pereiopods are most frequently thought of as "friction pads" of scales (Russell, 1962); however, the single row of propodal scales in a substantial number of pagurid genera, as noted above, could not provide much friction. Perusal of Table II will show that even among our small sample, the propodus of the fourth pereiopod quite commonly is provided with only a single row of comeous spines or scales, not the multiple-row rasp familiar to investigators of many of the shallow-water species. Although the reduction in the fourth pereiopods and development of propodal rasps may not appear directly related to carcinization, both are additional morphological attributes demonstrating an evolutionary trend away from the primitive elongate and simple appendage to a reduced and highly specialized one.

\section{Habitat}

Crypticism or protectionism is characteristic of nearly all paguroids except adults of the larger and more mobile genera of the Lithodinae and Probeebei, and for good reason. An even partially calcified or chitinized integument could be fatally vulnerable. Members of the Hapalogastrinae are commonly found in rocky crevices, as are species of some non-lithodid paguroid genera. Other paguroids have adapted to a host of available protection mechanisms. For Solitariopagurus and Porcellanopagurus, a clam shell serves the purpose nicely. For Paguropsis its chelate fourth pereiopods, and for Munidopagurus its spinose uropods, enable them to conveniently carry an anemone above their vulnerable abdomens, although this is not necessarily an obligate relationship (Provenzano, 1971). Pieces of wood provide an excellent shelter for Xylopagurus species, as do scaphopod shells for Pylopagurus and members of other genera. None of these protection devices require asymmetrical uropods or twisting of the abdomen. In fact, for some, there has been no need for propodal rasps either, With its greatly reduced abdomen, Labidochirus splendescens makes very good use of small gastropod shells that are readily covered by a growth of hydracti- 
nias. Its simple fourth pereiopods that are rarely able to be carried within the small shell are each provided with a small and relatively insignificant rasp, practically obscured by long setae. But for the vast majority of paguroids, what better safeguard could there be than abandoned gastropod shells to provide a movable shelter? The concept that shell resources are limiting factors for certain hermit crab populations is undoubtedly accurate, particularly in the often studied intertidal populations (see Elwood \& Neil, 1992 for review). However, as reported by Duris (1992), lack of available shells usually results in selection of a variety of alternative shelters. From the evidence presented, we can find no supporting data indicating that this limitation would cause paguroids to evolve a crab-like body form.

\section{Cladograms}

Initial application of PAUP 3.1 to the entire morphometric matrix resulted, as might be expected, in a staggering number of 17,000 trees of 469 steps when the analysis was halted. We illustrate (Fig. 14) a majority rule consensus tree. The majority rule provides a good overall idea of which taxa form clades. One can thus see the direction of evolutionary pathways, although, as indicated earlier, these are only results of a preliminary and partial analysis of the total array of possible data. The patterns of relationships among paguroid genera here does not support the traditional view that evolutionary pathways proceeded from pagurids to lithodids, but rather the reverse. The exception is the Pylochelidae, which in this context appear primitive. However, this is not surprising, since the evolutionary pathways being investigated are only pathways of carcinization. The pylochelids exhibit few, if any, characters associated with carcinization.

\section{An alternative hypothesis}

With the addition of a number of morphologically intermediate paguroid genera, it is clear that carcinization could not have provided a direct transition from a Pagurus-like genus to Lithodes. Nor

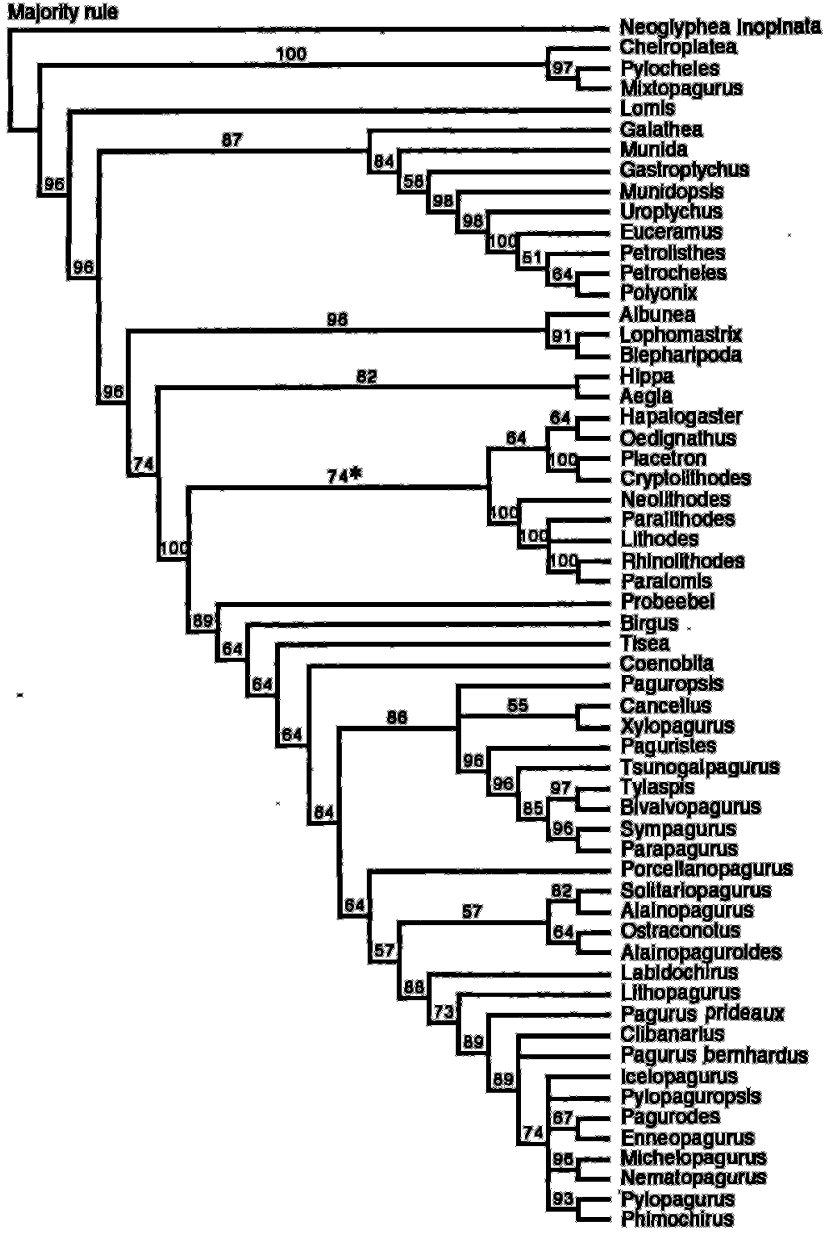

Fig. 14, Cladogram of anomuran taxa generated by majority rule consensus (* = lithodid clade).

does the evidence substantiate even gradual carcinization of a membranous, outstretched pagurid abdomen to ultimately produce the calcified, strongly flexed abdomen of the Lithodinae. However, a Bouvierian transition, if viewed in reverse, may present a viable hypothesis to corroborate a relationship between pagurids and lithodids. Certainly there is no single and direct pathway from lithodid to pagurid, nor is there any particularly cogent one. However, transition from a "crab-like" body form to a "hermit-crab" body form does appear feasible and could probably have included the following events:

1. Gradual change in the adult carapace shape 
from a crab-like, entirely calcified lithodid cephalothorax, through various phases of decalcification to the ultimate weakly calcified, generally flattened carapace of Pagurus-like genera.

2. Gradual reduction in the rostrum from the well-developed, frequently spiniform lithodid rostrum that usually overreaches the eyes, to markedly reduced and/or obsolete rostra of other paguroids.

3. Relaxation of abdominal somites three to six from their strong application against the sternum in the Lithodinae, through gradual loss of calcification in the abdominal integument, with concurrent reduction and finally obliteration of segmentation and accompanying increases in musculature to maintain turgidity through hydrostatic pressure.

4. Elongation of the now soft abdomen to better accommodate shell usage, with concurrent migration of elements of the reproductive and digestive systems into the abdomen.

5. Decrease from three pairs of well-developed ambulatory legs to only the first two pairs retaining an ambulatory function, but with parallel, albeit gradual, reduction and specialization of the third (fourth pereiopod).

6. Gradual reduction and/or loss in paired first female pleopods adapted for sexual or egg-carrying functions (cf. Pohle, 1989).

Carcinization, if meaning only acquisition of a crab-like body form, must be acknowledged as a fact. However, carcinization in the sense of Boas (1880a, b, 1924), Bouvier (1894a-c, 1895a, b, 1896,1897 ) and subsequent authors, meaning the evolution of a crab-like body form from a shelldwelling pagurid is, in our opinion fictious, not factual. Contrary to the hypothesis of Cunningham et al. (1992), the "king" (Paralithodes camtschatica) did not arise from a humble hermit heritage. Rather it were lithodids that began to experience integumental calcium loss, for reasons that at this point can only be hypothesized. It then follows that paguroids, over time, left the concealments common-place to the Hapalogastrinae. Some covered the now somewhat soft abdomen with objects such as halves of bivalve shells (e.g., Porcellanopagurus, Solitariopagurus), anemones (some parapagurids, Paguropsis, Munidopagurus, etc.). Others continued to use reclusive rock or coral shelters (e.g., Paguritta, Cancellus), and even sponges (cf. Sandford, 1994), while developing specialized adaptations. However, with the adoption of gastropod shells, hermit crabs gained not only a vastly more abundant concealment resource, but were provided greatly enhanced mobility, and with that, profound and rapid speciation.

\section{Acknowledgements}

We are deeply indebted to $\mathrm{Dr}$. Robert $\mathrm{H}$. Gore for allowing us to use him as a "sounding board" for our ideas. Galatheoid specimens were kindly provided by the late Janet Haig. The reviews of Drs. J.S. Buckeridge, UNITEC University, Auckland, A.W. Harvey, American Museum of Natural Hîstory, R.C.L. Pilgrim, University of Canterbury, Christchurch, F.R. Schram, University of Amsterdam, and an unknown reviewer were most helpful and are gratefully acknowledged. Prof. Schram and staff of the Institute for Systematics and Population Biology, University of Amsterdam are also thanked for having run the cladistic analyses. This is a scientific contribution from the Shannon Point Marine Center, Western Washington University.

\section{References}

Alcock, A., 1905. Anomura. Fasc. I, Pagurides. Catalogue of the Indian decapod Crustacea in the collections of the Indian Museum, 2: i-xi, 1-197 (Indian Museum, Calcutta).

Baba, K., 1988. Chirostylid and galatheid crustaceans (Decapoda: Anomura) of the "Albatross" Philippine Expedition, 1907-1910. Researches Crust., Spec. No. 2; 1-203.

Bate, C.S., 1888. Report on the Crustacea Macrura dredged by H.M.S. Challenger during the years 1873-76. In: Report on the scientific results of the voyage of H.M.S. Challenger during the years 1873-76, Zoology, 24(52): i$\mathrm{xc}, 1-942$.

Benedict, J.E., 1892. Preliminary descriptions of thirty-seven new species of hermit crabs of the genus Eupagurus in the U.S. National Museum. Proc. U.S. natn. Mus., 15: 1-26.

Benediet, J.E., 1895. Descriptions of new genera and species of crabs of the family Lithodidae with notes on the young of Lithodes camtschaticus and Lithodes brevipes. Proc. U.S. natn. Mus., 17: 479-488.

Benedict, J.E., 1901. The hermit crabs of the Pagurus bernhardus type. Proc. U.S. natn. Mus., 23: 451-466.

Benedict, J.E., 1904. A new genus and two new species of crustaceans of the family Albuneidae from the Pacific Ocean; with remarks on the probable use of the antennulae in Albunea and Lepidopa. Proc. U.S. natn. Mus., 27: 621-625.

Blackstone, N.W., 1989. Size, shell-living and carcinization 
in geographic populations of a hermit crab, Pagurus hirsutiusculus. J. Zool. Lond, 217: 477-490.

Boas, J.E.V., 1880a. II. Wissenschaftliche Mittheilungen. 1. Lithodes und Pagurus. Zool. Anz, 3: 349-352.

Boas, J.E.V., 1880b. Studier over decapodernes Slagtskabsforhold. K. dansk. Vidensk. Selsk. Skr., (5)6: 25-210.

Boas, J.E.V., 1924. Die verwandtschaftliche Stellung der Gattung Lithodes. K. dansk. Vidensk. Selsk. Skr., 4(4): 1-34.

Boone, L., 1926a. Unusual deep-sea Crustacea - some forms secured by the Arcturus Oceanographic Expedition. New York zool. Soc. Bull., 29: 69-72.

Boone, L., 1926b. A new family of Crustacea. Preliminary technical description. New York zool. Soc. Bull., 29: 73.

Borradaile, L.A., 1916. Crustacea. Part II. Porcellanopagurus: An instance of carcinization. In: British Antarctic ("Terra Nova") Expedition, 1910. Natural History Report. Zoology, 3(3): 111-126.

Bourne, G.C., 1922. The Raninidae: A study in carcinology. J. Linn. Soc. London, Zool, 35: 25-79.

Bosc, L.A.G., 1802, Histoire Naturelle des Crustacés, contenant leur description et leurs moeurs; avec figures dessinées d'après nature, 2: 1-296, pls. 9-18 (De Guilleminet, Paris).

Bouvier, E.L., 1894a. Sur les caractères et l'évolution des Lomisinés, nouveau groupe de Crustacés anomures. C.r. hebd. Séanc. Acad. Scí, 118: 1353-1355.

Bouvier, E.L., 1894b. Sur la signification de Hapalogaster dans l'évolution des Lithodinés. C.r. somm. Séanc. Soc. philom. Paris, 18: 1-5.

Bouvier, E.L., 1894c. Sur la transformation des Paguriens en crabes anomures de la sous-famille des Lithodinés. C.r. hebd. Séanc. Acad. Sci., 119: 350-352.

Bouvier, E.L., 1895a. Sur les Lithodinés hapalogastriques Hapalogaster et Dermaturus. C.r. somm. Séanc. Soc. philom. Paris, No. 18: 56.

Bouvier, E.L, 1895b. Recherches sur les affinitès des Lithodes \& des Lomis avec les Pagurides. Annls. Sci. nat., (7) 18: 157-213.

Bouvier, E.L, 1896. Sur la classification des Lithodinés et sur leur distribution dans les océans. Annls. Sci. nat., (8) 1: $1-46$.

Bouvier, E.L., 1897. La transformation des Bernards 1'Ermite en Lithodes. Naturaliste, (2) 19 (230): 41-43.

Bouvier, E.L., 1940. Faune de France, 37. Décapodes Marcheurs: 1-404 (P. Lechevalier, Paris).

Brandt, J.F., 1848. Die Gattung Lithodes Latreille nebst vier neuen ihr verwandten von Wosnessenski entdeckten, als Typen einer besonderen Unterabtheilung (Tribus Lithodea) der Edward'schen Anomuren. Bull. Cl. phys.-math. Acad. Sci. St. Pétersbourg, 7: 171-176.

Brandt, J,F, 1850. Vorlaũfige Bermerkungen über eine aus zwei noch unbeschriebenen Gattungen und Arten gebildete Unterabtheilung (Hapalogastrica) der Tribus Lithodea, begleitet von einer Charakeristik der eben genannten Tribus der Anomuren. Bull. Cl. phys.-math. Acad. Sci. St. Pétersbourg, 8 (16-17): 266-269.

Brandt, J.F., 1851. Krebse. In: A. Th. v. Middendorff, Reise in den âussersten Norden und Osten Sibiriens während der Jahre 1843 und 1844, 2. Zoologie (1): 77-14, pls. VVII (Kais. Akad. Wiss., St. Petersburg).

Caullery, M, 1896. Crustacés Schìzopodes et Décapodes. In: R. Koehler, Résultats scientifiques de la Campagne du "Caudan" dans le Golfe de Gascogne, août-septembre, 1895. Annls. Univ. Lyon, 26: 365-419.

Chace, F.A., Jr, 1939. Report on the scientific results of the first Atlantis Expedition to the West Indies, etc. Preliminary descriptions of one new genus and seventeen new species of decapod and stomatopod Crustacea. Memorias Soc. cub. Hist. nat, 13: 31-54.

Chace, F.A., Jr., 1942. Reports on the scientific results of the Atlantis Expeditions to the West Indies, under the joint auspices of the University of Havana and Harvard University. Torreia, 11: 1-106.

Coffin, H.G., 1957. A new southern form of "Pagurus hirsutiusculus" (Dana) (Crustacea, Decapoda). Walla Walla Coll. Publs. Dep. biol. Sci., 21: 1-8.

Crain, J.A. \& P.A. MeLaughlin, 1994. Larval, postlarval, and early juvenile development in Pagurus venturensis Coffin, 1957 (Decapoda, Anomura, Paguridae) reared in the laboratory, with a redescription of the adult. Bull. mar. Sci., 53 (3) "1993": 985-1012.

Cunningham, C.W., N.W. Blackstone \& L.W. Buss, 1992. Evolution of king crabs from hermit crab ancestors. Nature, Lond., 355: 539-542.

Dana, J.D., 1851. Conspectus Crustaceorum quae in orbis terrarum circumnavigatione, Carolo Wilkes e classe reipublicae foederatae duce, lexit et descripsit. (Preprint from) Proc. Acad. nat. Sci., Philad., 5: 267-272.

Dana, J.D., 1852a. Conspectus Crustaceorum, \&c. Conspectus of the Crustacea of the Exploring Expedition under Capt. Wilkes, U.S.N., including the Paguridea, continued, the Megalopidea, and the Macroura. Paguridea, continued, and subtribe Megalopidea. (Preprint from) Proc. Acad. nat. Sci. Philad., 6: 6-28 (1854).

Dana, J.D., 1852b. Crustacea, part II. United States Exploring Expedition. During the years 1838, 1839, 1840, 1841, 1842. Under the command of Charles Wilkes, U.S.N., 13: 686-1618 (C. Sherman, Philadelphia; reprinted in 1972 by Antiquariaat Junk, Lochem, The Netherlands).

Duris, Z, 1992. On a small collection of Crustacea Decapoda from the Bellsund region, Spitsbergen. In: J. Repelewska-Pekalowa \& $\mathrm{K}$. Pekala (eds.). Wyprawy Geografiezne na Spitsbergen: 121-154 (UMCS, Lubin, Poland).

Elwood, R.W. \& S.J. Neil, 1992. Assessments and decisions. A study of information gathering by hermit crabs: 1-192 (Chapman \& Hall, London etc.).

Fabricius, J.C., 1775. Systema entomologiae, sistens Insectorum classes, ordines, genera, species, adiectis synonymis, locis, descriptionibus, observationibus: [i-xxxii], 1-832 (Officina Libraria Kortiî, Flensburgi et Lipsiae).

Fabricius, J.C., 1787. Mantissa Insectorum sistens eorum species nuper detectas adjectis characteribus genericis, differentiis specificis, emendationibus, observationibus, 1: 1-xx, 1-348 (C.G. Proft, Hafniae).

Fabricius. J.C., 1793. Entomologia systematica emendata et 
aucta, secundum classes, ordines, genera, species, adjectis synonimis, locis, observationibus, descriptionibus, 2: i-viii, 1-519 (C.G. Proft, Hafniae).

Fabricius, J.C., 1798. Supplementum entomologiae systematicae: [i-iv], 1-572 (C.G. Proft, Hafniae).

Faxon, W., 1893. Reports on the dredging operations off the west coast of Central America to the Galapagos, to the west coast of Mexico, and in the Gulf of California, in charge of Alexander Agassiz, carried out by the U.S. Fish Commission steamer "Albatross" during 1891, Lieut.Commander Z.L. Tanner, U.S.N., commanding, VI. Preliminary descriptions of new species of Crustacea. Bull. Mus. comp. Zool., Harv., 24 (7): 149-220.

Feldmann, R.M., 1984. Haumuriaegla glaessneri n. gen. and sp. (Decapoda; Anomura; Aeglidae) from Haumurian (Late Cretaceous) rocks near Cheviot, New Zealand. N.Z. J. Geol. Geophys., 27: 379-385.

Filhol, H., 1885. Description d'un nouveau genre de Crustacé provenant de la Nouvelle-Zélande. Bull. Soc. philom. Paris, (7) 9: 47-48.

Forest, J., 1951a. Contribution à l'étude du genre Porcellanopagurus Filhol (Paguridae), 1. Description de P. edwardsi Filhol. Bull. Mus. natn. Hist, nat,, (2) 23: 82-90.

Forest, J., 1951b. Contribution à l'étude du genre Porcellanopagurus Filhol (Paguridae), 2. Remarques systématiques et biologiques. Bull. Mus. natn. Hist. nat., (2) 23: 181186.

Forest, J., 1987. Les Pylochelidae ou "Pagures symétriques" (Crustacea Coenobitoidea). In: Résultats des Campagnes MUSORSTOM, 3. Mém. Mus. natn. Hist. nat, (Zool.) 137: 1-254.

Forest, J., 1995. Crustacea Decapoda Anomura: Révision du genre Trizopagurus Forest, 1952 (Diogenidae), avec l'établissement de deux genres nouveaux. In: A. Crosnier (ed.), Résultats des Campagnes MUSORSTOM, 13. Mém. Mus, natn. Hist. nat., (Zool.) 163: 9-149.

Forest, J. \& M. de Saint Laurent, 1975. Présence dans la faune actuelle d'un représentant du groupe mésozoĩque des Glyphẻides: Neoglyphea inopinata gen. nov., sp. nov. (Crustacea Decapoda Glypheidae). C.r. hebd. Séanc. Acad. Sci. Paris, (D) 281: 155-158.

Forest, J. \& M. de Saint Laurent, 1981. La morphologie externe de Neoglyphea inopinata, espèce actuelle de Crustacé Décapode Glyphéide. In: Résultats des Campagnes MUSORSTOM, 1. Philippines (18-28 mars 1976). Mém. ORSTOM, 91: 51-84.

Forest, J. \& M. de Saint Laurent, 1989. Nouvelle contribution à la connaissance de Neoglyphea inopinata Forest \& de Saint Laurent, à propos de la description de la femelle adulte. In: J, Forest (ed.), Résultats des Campagnes MUSORSTOM, 5. Mém. Mus. natn. Hist. nat., (Zool.) 144: 75-92.

García-Gómez, J., 1988. A new genus and three new species of hermit crabs (Crustacea: Decapoda: Paguridae) from the western Atlantic Ocean. Bull. mar. Sci., 42(1): 44-64.

Glaessner, M.F., 1957. Evolutionary trends in Crustacea (Malacostraca). Evolution, 11: 178-184.

Goffinet, G. \& Ch. Jeuniaux, 1994. Le tégument: morpholo- gie et biochimie. In: P.-P. Grassé \& J. Forest (eds.), Traité de zoologie. Anatomie, systématique, biologie, 7(1): 4990 (Masson, Paris etc.).

Gore, R.H., 1974. On a small collection of porcellanid crabs from the Caribbean Sea (Crustacea, Decapoda, Anomura). Bull. mar. Sci., 24: 700-721.

Guérin-Méneville, F.E., 1853. III. Mélanges et nouvelles. Revue Mag. Zool, (2) 5: 45-48.

Guérin-Méneville, F.E., 1855. In: R. de la Sagra (ed.), Historia fisica, política y natural de la isla de Cuba. Vol. 8, Atlas de Zoologia. Crustáceos, Arácnidos y Insectos: pls. 120 (A. Bertrand, Paris).

Guinot, D., 1979. Données nouvelles sur la morphologie, la phylogenèse et la taxonomie des Crustacés Décapodes Brachyoures. Mém. Mus. natn. Hist. nat., (A, Zool.) 112: 1-354.

Haan, W. de, 1833-1850. Crustacea. In: P.F, von Siebold, Fauna Japonica sive descriptio animalium, quae in itinere per Japoniam, jussu et auspiciis superiorum, qui summum in India Batava Imperium tenent, suscepto, annis 18231830 collegit, notis, observationibus et adumbrationibus illustravit. Fasc. 1-8: i-xvi, vii-xvii, i-xxxi, 1-243, pls. ILV, 1-2, A-Q (apud auctorem, Lugduni Batavorum \& J. Müller \& Co. Amstelodami).

Harms, J.W., 1932. Die Realisation von Genen und die consecutive Adaptation. II. Birgus latro L. als Landkrebs und seine Beziehungen zu den Coenobiten. Zeitschr. wisss. Zool., 140: 167-288.

Harms, J.W., 1938. Lebensablauf und Stammesgeschichte des Birgus latro L. von der Weihnachtsinsel. Zeitschr. Naturwiss. Jena, 75: 1-34.

Hart, J.F.L., 1982. Crabs and their relatives of British Columbia. British Columbia Provincial Museum Handbook, 40: 1-266.

Henderson, J.R., 1885. In: T.H. Tizard et al,, Narrative of the cruise of the H.M.S. Challenger with a general account of the scientific results of the expedition. Report on the scientific results of the voyage of H.M.S. Challenger, during the years 1873-76, 1(2): 511-1110 (Her Majesty's Statiónary Office, Edinburgh etc.).

Henderson, J.R., 1888. Report on the Anomura collected by H.M.S. Challenger during the years 1873-76. Report on the scientific results of the exploratory voyage of H.M.S. Challenger, (Zoology) 27: i-xi, 1-221, pls. I-XXI (Her Majesty's Stationary Office, Edinburgh etc.).

Herbst, J.F.W., 1791-96. Versuch einer Naturgeschichte der Krabben und Krebse nebst einer systematischen Beschreibung ihrer verschiedenen Arten, 2. Krebse: i-viili, 1226, pls. XXI-XLIV (G.A. Lange, Berlin/Stralsund).

Hobbs, H.H., III, 1979. A new species of the endemic South American genus Aegla from Paraná, Brazil (Crustacea: Anomura: Aeglidae). Proc. biol. Soc. Wash., 91(4): 982988.

Kropp, R.K., 1986. A neotype designation for Petrolisthes tomentosus (Dana), and description of Petrolisthes heterochrous, new species, from the Mariana Islands (Anomura: Porcellanidae). Proc. biol. Soc. Wash., 99(3): 452-463.

Kunze, J. \& T. Anderson, 1979. Functional morphology of 
the mouthparts and gastric mill in the hermit crabs Clibanarius taeniatus (Milne Edwards), Clibanarius virescens (Krauss), Paguristes squamosus McCulloch and Dardanus setifer (Milne Edwards) (Anomura: Paguridae). Aust. J. mar. Freshwater Res., 30: 683-722.

Lafon, M., 1948. Nouvelles recherches biochìmiques et physiologiques sur le squelette tégumentaire des Crustacés. Bull. Inst. océanogr. Monaco, 45 (939): 1-28.

Lamarck, J.B.P.A. [Monet, chevalier de], 1801. Système des animaux sans vertèbres, ou tableau général des classes, des ordres et des genres de ces animaux; présentant les caractères essentiels et leur distribution, d'après la considération de leurs rapports naturels et de leur organisation, et suivant l'arrangement établi dans les galeries du Muséum d'Hist. Naturelle, parmi leur dépouilles conservées; précédé du díscours d'ouverture du cours de zoologie, donné dans le Muséum National d'Histoire Naturelle l'an 8 de la République: i-viii, 1-432 (chez 1'auteur \& Déterville, Paris).

Lamarck, J.B.P.A. [Monet, chevalier de], 1818. Histoire naturelle des animaux sans vertèbres, présentant leurs caractères généraux et particuliers de ces animaux, leur distribution, leurs classes, leurs familles, leurs genres, et la citation des principales espèces qui s'y rapportent; précédée d'une introduction offrant la détermination des caractères essentiels de l'animal, sa distinction du végétal et des autres corps naturels, enfin, l'exposition des principes fondamentaux de la zoologie, 5; 1-iii, 1-612 (Déterville \& Verdière, Paris).

Latreille, P.A, 1806. Genera Crustaceorum et Insectorum secundum ordinem naturalem in familias disposita, iconibus exemplisque plurimis explicata, 1: 1-302 (Treuttel et Würtz, Parisilis et Argentorati).

Latreille, [P.A.], 1829. Crustacés, Arachnides et partie des Insectes. In: [G.] Cuvier, Le règne animal distribué d'après son organisation, pour servir de base à l'histoire naturelle des animaux et d'introduction à l'anatomie comparée (éd. 2), 4: i-xxvii, 1-584 (Déterville \& Crochard, Paris).

Laurent, R.F., 1983. Irreversibility: A comment on Macbeth's interpretations. Syst. Zool., 32: 75.

Leach, W.E., 1815. A tabular view of the external characters of four classes of animals, which Linné arranged under Insecta; with the distribution of the genera composing three of these classes into orders, \&c. and descriptions of several new genera and species. Trans. Linn. Soc. Lond., 11: 306-400.

Leach, W.E., 1820. Galatéadées. Dictionnaíre des Sciences Naturelles, 18: $49-56$ (F.G. Levrault \& Le Normant, Strasbourg/Paris).

Lemaitre, $R_{n}, 1989$. Revision of the genus Parapagurus (Anomura: Paguroidea: Parapaguridae), including redescriptions of the western Atlantic species, Zool. Verh. Leiden, 253: 1-106.

Lemaitre, R., 1993. A new genus of Parapaguridae (Decapoda: Anomura). Crust. Res., 22: 11-20.

Lemaitre, R., 1994. Crustacea Decapoda: Deep-water hermit crabs (Parapaguridae) from French Polynesia with de- scriptions of four new species. In: A. Crosnier (ed.), Résultats des Campagnes MUSORSTOM, 12. Mém. Mus. natn. Hist. nat, (Zool.) 161: 375-419.

Lemaitre, R., 1995. A review of the hermit crabs of the genus Xylopagurus A. Milne Edwards, 1880 (Crustacea: Decapoda: Paguridae), including descriptions of two new species. Smithson. Contr. Zool, 570: 1-27.

Lemaitre, $R_{n}, 1996$. Hermit crabs of the family Parapaguridae (Crustacea: Decapoda: Anomura) from Australia: Species of Strobopagurus Lemaitre, 1989, Sympagurus Smith, 1883 and two new genera. Rec. Aust. Mus., 48: 163-221.

Lemaitre, R., (in press). Crustacea Decapoda: Revisiting Tylaspis anomala Henderson, 1885 (Parapaguridae), with comments on its relationships and evolutionary significance. Zoosystemả.

Lemaitre, R. \& N.H. Campos, 1993. Two new hermit crabs (Crustacea: Decapoda: Paguridae) from the Caribbean Sea. Proc. biol. Soc. Wash., 106(3): 554-565.

Lemaitre, R. \& P.A. McLaughlin, 1995. Alainopagurus crosnieri n. gen., n. sp. (Decapoda: Anomura: Paguridae) from the western Pacific. Bull. Mus. natn. Hist. nat., (4) 17A (3-4): 273-282.

Linnaeus, $C$., 1758. Systema naturae per regna tria naturae, secundum classes, ordines, genera, species, cum characteribus, differentiis, synonymis, locis (ed. 10), 1: 1-iv, 1824 (Laurentii Salvii, Holmiae).

Linnaeus, C., 1767. Systema naturae per regna tria naturae, secundum classes, ordines, genera, species, cum characteribus, differentiis, synonymis, locis (ed. 12), 1(2): 5331327, [1-33] (Laurentii Salvii,, Holmiae).

Macpherson, E., 1988. Revision of the family Lithodidae Samouelle, 1819 (Crustacea, Decapoda, Anomura) in the Atlantíc Ocean. Monografias de Zoologia marina, 2: 1153.

Man, J.G. de, 1902. Die von Herrn Professor Kükenthal im Indischen Archipel gesammelten Dekapoden und Stomatopoden. Abh. Senckenb. naturforsch. Ges., 25: 467-939, pls. XIX-XXVII.

Martin, J.W. \& L.G. Abele, 1986. Phylogenetic relationships of the genus Aegla (Decapoda: Anomura: Aeglidae), with comments on anomuran phylogeny. J. crust. Biol, 6: 576616.

Martin, J.W. \& L.G. Abele, 1988. External morphology of the genus Aegla (Crustacea: Anomura: Aeglidae). Smithson. Contr. Zool., 453: 1-46.

McLaughlin, P.A., 1974. The hermit crabs (Crustacea Decapoda, Paguridea) of northwestern North America. Zool. Verh. Leiden, 130: 1-396.

McLaughlin, P.A., 1980. Comparative morphology of Recent Crustacea: 1-177 (W.H. Freeman \& Co., San Francisco/ New York).

McLaughlin, P.A., 1981. Revision of Pylopagurus and Tomopagurus (Crustacea: Decapoda: Paguridae), with the descriptions of new genera and species: Part I. Ten new genera of the Paguridae and a redescription of Tomopagurus A. Milne Edwards and Bouvier. Bull. mar. Sci., 31(1): 1-30. 
McLaughlin, P.A., 1983a. A review of the phylogenetic position of the Lomidae (Crustacea: Decapoda: Anomala). J. crust. Biol., 3: 431-437. "

McLaughlin, P.A., 1983b. Hermit crabs - Are they really polyphyletic? J. crust. Biol., 3: 608-621.

McLaughlin, P.A., 1997. Crustacea Decapoda: Hermit crabs of the family Paguridae from the KARUBAR expedition in Indonesia. In: A. Crosnier \& P. Bouchet (eds.), Résultats des Campagnes MUSORSTOM, 16. Mém. Mus. natn. Hist. nat, (Zool.) 172: 433-572.

McLaughlin, P.A. \& S.W. Gunn, 1992. Revision of Pylopagurus and Tomopagurus (Crustacea: Decapodax Paguridae), with the descriptions of new genera and species: Part IV. Lophopagurus McLaughlin and Australeremus MeLaughlin. Mem. Mus. Victoria, 53(1): 43-99.

McLaughlin, P.A. \& J.F. Hebard, 1960. Stomach contents of Bering Sea king crabs. Spec. scient. Rep. (Fish.), 293: 15.

MeLaughlin, P.A. \& L.B. Holthuis, 1985. Anomura versus Anomala. Crustaceana, 49: 204-209.

Melin, G., 1939. Paguriden und Galatheiden von Prof. Dr. Sixten Bocks Expedition nach den Bonin-Inseln 1914. Kungl. svenska VetenskAkad. Handl, (3) 18 (2): 1-119.

Miers, E.J., 1876. Descriptions of some new species of Crustacea, chiefly from New Zealand. Ann. Mag. nat. Hist., (4) 17: 218-229.

Miers, E.J., 1879. Revision of the Hippidea. J. Linn. Soc., (Zool.) 14: 312-336, pl. 5.

Milne Edwards, A, 1862. Faune carcinologique de l'Ile Bourbon (Extrait). Annls. Sci. nat., (Zool.) (4) 17: 362.

Milne Edwards, A, 1880. Report on the results of dredging, under the supervision of Alexander Agassiz, in the Gulf of Mexico, and in the Caribbean Sea, 1877, 78, 79, by the United States Coast Survey steamer "Blake", Lieut.-Commander C.D. Sigsbee, U.S.N., and Commander J.R. Bartlett, U.S.N., commanding. VIII. Etudes préliminaires sur les Crustacés. Bull. Mus. comp. Zool. Harv., 8(1): 1-68.

Milne Edwards, A, 1891. Pagurides nouveaux des Açores. Campagnes scientifiques de S.A. Le Prince de Monaco sur le yacht 1'Hirondelle. Bull. Soc. zool. Fr., 16: 131134.

Mîlne Edwards, A. \& E.L. Bouvier, 1891. Observations générales sur les Paguriens recueillis dans la mer des Antilles et le Golfe du Mexique, par le Blake et le Hassler, sous la direction de M. Alexandre Agassiz. Bull. Soc. philomath. Paris, (8) 3(1): 102-110.

Milne Edwards, A. \& E.L. Bouvier, 1892. Observations préliminaires sur les Paguriens recueillis par les expéditions du Travailleur et du Talisman. Annls. Sci. nat., Zool. Paléont, (7)13: 185-226.

Milne Edwards, A. \& E.L. Bouvier, 1893. Reports on the results of dredging, under the supervision of Alexander Agassiz, in the Gulf of Mexico (1877-78), in the Caribbean Sea (1878-79), and along the Atlantic coast of the United States (1880), by the U.S. Coast Survey Steamer "Blake", Lieut.-Commander C.D. Sïgsbee, U.S.N. and Commander J.R. Bartlett, U.S.N., commanding. XXXIII. Description des Crustacés de la famille des Paguriens re- cueillis pendant l'expédition. Mem. Mus. comp. Zool. Harv., 14(3): 5-172.

Milne Edwards, A. \& E.L. Bouvier, 1894a. Considérations générales sur la famille des Galathéidés. Annls. Scì nat., 14: 191-327.

Milne Edwards, A. \& E.L. Bouvier, 1894b. Troisiè̀me campagne du yacht 1'Hirondelle, 1887. Neolithodes, genre nouveau de la sous-famille des Lithodinés. Bull. soc.

- Zool. Fr., 19: 120-122.

Milne Edwards, $H_{\text {, }}$ 1831. Recherches sur l'organisation et la classification naturelle des Crustacés Décapodes. Annls. Sci. nat., (1) 25: 298-332.

Milne Edwards, $H_{\text {, }}$ 1836. Observations zoologiques sur les Pagures et description d'un nouveau genre de la tribu des Paguriens. Annls. Sci. nat., (Zool.) (2) 6: 257-288.

Mîlne Edwards, $\mathrm{H}_{\text {, }}$ 1837. Histoìre naturelle des Crustacếs, comprenant 1'anatomie, la physiologie et la classification de ces animaux, 2: [i-iii], 1-532 (Librairie Encyclopédique de Roret, Paris).

Milne Edwards, H. \& H. Lucas, 1841. Description des Crustacés nouveaux ou peu connus conservés dans la collection du Muséum."Archs. Mus. Hist. nat. Paris, 2: 461-483.

Míyazaki, K. \& K. Jozuka, 1964. Uptake and turnover of ${ }^{45} \mathrm{Ca}$ by the crayfish, Procambarus clarkii. Annual Rep. Noto mar. Lab. Fac. Sci. Univ. Kanazawa, 4: 111-120.

Monod, Th., 1956. Hippidea et Brachyura ouest-africains. Mém. Inst. fr. Afr. noire, 45: 1-674.

Morgan, G.J. \& J. Forest, 1991. A new genus and species of hermit crab (Crustacea, Anomura, Diogenidae) from the Tímor Sea, north Australia. Bull. Mus. natn. Hist. nat, Paris (4) (A, Zool.) 13: 189-202.

Nixon, K.C. \& J.M. Carpenter, 1993. On outgroups. Cladistics, $9 ; 413-426$.

Ortmann, A., 1892. Die Decapoden-Krebse des Strassburger Museums, mit besonderer Berücksichtïgung der von Herm Dr. Döderlein bei Japan und beì den Liu-Kiu-Inseln gesammelten und zur Zeit im Strassburger Museum aufbewahrten Formen, IV . Die Abtheilungen Galatheidea und Paguridea. Zool. Jb., (Syst.) 6: 241-326, pls. 11-12.

Osawa, M., 1995. A new parapagurid genus, Tsunogaipagurus, for Sympagurus chuni (Balss, 1911) (Crustacea: Decapoda: Anomura). Proc. Japan Soc. syst. Zool., (53): 62 70.

Owen, R., 1839. Crustacea. In: F.W. Beechey (ed.), The zoology of Captain Beechey's voyage; comp. from the collections and notes made by Captain Beechey, the officers and naturalist of the expedition to the Pacific and Behring's straits performed in His Majesty"s ship "Blossom", under the command of Captain F.W. Beechey $\ldots$ in the years 1825, 26, 27 and 28: 77-92 (H.G. Bohn, London).

Pérez, C., 1934. Exposés de bíologie zoologique, I. Les Pagures ou Bernard l'ermite (un example d'adaptation). Actualités scientifiques et industrielles, Paris, 101: 1-33.

Pilgrim, R.L.C., 1965. Some features in the morphology of Lomis hirta (Lamarck) (Crustacea: Decapoda) and a discussion of its systematic position and phylogeny. Aust. J. Zool., 13: 545-557. 
Pilgrim, R.L.C., 1973. Axial skeleton and musculature in the thorax of the hermit crab, Pagurus bernhardus [Anomura: Paguridae]. J. mar. Biol. Ass. U.K., 53: 363-396.

Pohle, G., 1989. Gill and embryo grooming in lithodid crabs: Comparative functional morphology based on Lithodes maja. In: B.E. Felgenhauer, L. Watling \& A.B. Thistle (eds.), Functional morphology of feeding and grooming in Crustacea. Crustacean Issues, 6: 75-94 (A.A. Balkema, Rotterdam).

Poore, G.C.B., 1994. A phylogeny of the families of Thalassinidae (Crustacea: Decapoda) with keys to families and genera. Mem. Mus. Victoria, 54: 19-120.

Poupin, J. \& P.A. McLaughlin, 1996. A new species of Solitariopagurus Türkay (Decapoda: Paguridae) from French Polynesia. Bull. Mus. natn. Hist. nat., Paris, (4) 18 (A, Zool.) (1/2): 211-224.

Powell, G.C., 1974, Gregarious king crabs. Sea Frontiers, 20: 206-211.

Provenzano, A.J., Jr., 1968. Biological investigations of the deep sea, 37. Lithopagurus yucatanicus, a new genus and species of hermit crab with a distinctive larva. Bull. mar. Sci., 18: 627-644.

Provenzano, A.J., Jr., 1971. Rediscovery of Munidopagurus macrocheles (A. Milne-Edwards, 1880) (Crustacea, Decapoda, Paguridae), with a description of the first larval stage. Bull, mar. Sci, 21(1): 256-266.

Rabaud, E., 1941. Recherches sur 1'adaptation et le comportement des Pagures. Archs. Zool. exp. gén., 82: 181-285.

Randall, J.W., 1840. Catalogue of the Crustacea brought by Thomas Nuttall and J.K. Townsend, from the west coast of North America and the Sandwich Islands, with descriptions of such species as are apparently new .... J. Acad. nat. Sci. Philad., 8: 106-147.

Rensch, B, 1959. Evolution above the species level: 1-419 (Methuen \& Co., Ltd., London).

Richter, S. \& G. Scholtz, 1994. Morphological evidence for a hermit crab ancestry of lithodids (Crustacea, Decapoda, Anomala, Paguroidea). Zool. Anz, 233 (5/6): 187-210.

Russell, E.S., 1962. The diversity of animals. An evolutionary study. Acta biotheor, 11: 1-151.

Saint Laurentt, $M \times$ de, 1968. Révision des genres Catapaguroídes et Cestopagurus et description de quatre genres nouveaux, I. Catapaguroides A. Milne Edwards et Bouvier et Decaphyllus nov* gen. (Crustacés Décapodes Paguridae). Bull. Mus. natn. Hist. nat., (2) 39 (5) ("1967"): 923-954.

Saint Laurent, M. de, 1979. Vers une nouvelle classification des Crustacés Décapodes Reptantia. Bull. Off. natn. Pêch. Tunisie, 3: 15-31.

Saint Laurent-Dechancé, M. de, 1966. Iridopagurus, genre nouveau de Paguridae (Crustacés Décapodes) des mers tropicales américaines. Bull. Mus. natn. Hïst. nat., (2) $38(2) \times 151-173$.

Sandberg, L. \& P.A. McLaughlin, 1997 (in press). Crustacea, Decapoda, Paguridea. Marine invertebrates of Scandinavia, 10 (Universitetsforlaget, Oslo).

Sandford, F., 1994. The Florìda hermit-crab sponge, a little known "mobile" sponge from the N.E. corner of the Gulf of Mexico, and its hermit crab associates. In: R.W.M. van Soest, T.M.G. van Kempen \& J.-C. Braekman (eds.), Sponges in time and space. Biology, chemistry, paleontology. Proceedings of the IV International Porifera Conference, Amsterdam, April 1993: 273-277 (A.A. Balkema, Rotterdam).

Saussure, M.H. de, 1857. Diagnoses de quelques Crustacés nouveaux de l'Amérique tropícale. Revue Mag. Zool., (2) 9: 501-505.

Say, $T$, 1817. An account of the Crustacea of the United States. J. Acad. nat. Sci. Philad., 1: 155-169.

Schalfeew, P., 1892. Carcinologische Bemerkungen aus dem Zoologischen Museum der Kaiserlichen Akademie der Wissenschaften. Bull. Acad. imp. Sci. St. Pétersbourg, 35: 331-342.

Schembri, P.J., 1982. Feeding behaviour of fifteen species of hermit crabs (Crustacea: Decapoda: Anomura) from the Otago region, southeastern New Zealand. J. nat. Hist., 16: 859-878.

Schmitt, W.L., 1921. The marine decapod Crustacea of California with special reference to the decapod Crustacea collected by the United States Bureau of Fisheries Steamer "Albatross" in connection with the biological survey of San Francisco Bay during the years 1912-1913. Univ. Calif. Publs. Zool., 23: 1-470.

Schmitt, W.L., 1935. Crustacea Macrura and Anomura of Porto Rico and the Virgin Islands. Scientific survey of Porto Rico and the Virgin Islands, New York Acad. Sci., 15(2): 125-227.

Schmitt, W.L., 1942. The species of Aegla, endemic South American freshwater crustaceans. Proc. U.S. natn. Mus., 91: 431-520.

Scholtz, G. \& S. Richter, 1995. Phylogenetic systematics of the reptantian Decapoda (Crustacea, Malacostraca). Zool. J. Linn. Soc., 113: 289-328.

Scopoli, G.A., 1777. Introductio ad historiam naturalem sistens genera lapidum, plantarum, et animalium hactenus detecta, caracteribus essentialibus donata, in tribus divisa, subinde ad leges naturae: [i-x], 1-506, [1-34] (W. Gerle, Pragae).

Sluys, R., 1992. Evolutionary side-steps. Bijdr. Dierk, 62(2): 121-126.

Smith, S.I., 1879. The stalk-eyed Crustaceans of the Atlantic coast of North America north of Cape Cod. Trans, Conn. Acad. Arts Sci., 5(1): 27-136.

Smith, S.I., 1883. Preliminary report on the Brachyura and Anomura dredged in deep water off the south coast of New England by the United States Fish Commission in 1880, 1881, and 1882. Proc. U.S. natn. Mus., 6(1): 21-57.

Snodgrass, R.E., 1952. The sand crab Emerita talpoida (Say) and some of its relatives. Smithson. misc. Coll, 117(8): 1-34.

Spears, T., L.G. Abele \& W. Kim, 1993. The monophyly of brachyuran crabs: A phylogenetic study based on $18 \mathrm{~S}$ rRNA. Syst. Biol., 41 ("1992"): 446-461.

Stebbing, T.R.R., 1893. A history of Crustacea. Recent Malacostraca: 1-466 (Kegan Paul, Trench, Trübner \& Co. Ltd., London). 
Števčić, Z., 1971. The main features of brachyuran evolution. Syst. Zool, 20: 331-340, *

Stevens, B.A., 1927. Orthopagurus, a new genus of Paguridae from the Pacific coast. Publs. Puget Sound mar. biol. $S t_{n}, 5: 245-252$.

Stevenson, J.R., 1985. Dynamics of the integument. In: D.E. Bliss \& L.H. Mantel (eds.), The biology of Crustacea, 9. Integument, pigments, and hormonal process: 1-42 (Academic Press, Inc., New York).

Stimpson, W., 1858. Prodromus descriptionis animalium evertebratorum, quae in expeditione ad Oceanum Pacificum Septentrionalem, a Republica Federate missa, Cadwaladaro Ringgold et Johanne Rodgers ducibus, observavit et descripsit, VII. [Preprint (December 1858) from] Proc. Acad. nat. Sci. Philad., 10: 225-252.

Stimpson, W., 1860. A trip to Beaufort, North Carolina. Amer. J. Sci. Arts, (2)29: 442-445.

Studer, Th, 1883. Verzeichniss der während der Reise S.M.S. "Gazelle" an der Westkūste von Afrika, Ascension und dem Cap der Guten Hoffnung gesammelten Crustaceen. Abh. Akad. wiss. Berlin., Phys. Abh., 2 "1882": 132.

Swammerdam, J., 1737. Biblia naturae; sive historia Insectorum, in classes certas redacta, nec non exemplis, et anatomico variorum animalculorum examine, aeneisque tabulis illustrata. Insertis numerosis rariorum naturae observationibus. Bybel der Natuure, of historie der insecten, tot zeekere zoorten gebracht: door voorbeelden, ontleedkundige onderzoekingen van veelerhande kleine gediertens, als ook door kunstige kopere plaaten opgeheldert. Verrijkt met ontelbaare waarnemingen van nooit ontdekte zeldzaamheden in de natuur, 1: [i-1xii], 1-550 (I. Severinus, B. van der Aa \& P. van der Aa, Leyden).

Tilesíus, W.G., 1815. De cancris camtschaticis, oniscis, entomostracis et cancellis marinis microscopicis noctilucentibus, cum tabulis IV: aenaeis et appendice adnexo de acaris et ricinis Camtschaticis. Conventui exhibuit die 3 Februarii 1813. Mém. Acad. impér. Sci. St. Pétersbourg, $5 \times 331-405$.
Tudge, C.C., 1997. Spermatological evidence supports the taxonomic placement of the Australian endemic hairy stone crab, Lomis hírta (Decapoda: Anomura: Lomidae). Mem. Mus. Vict., 56(1): 235-244.

Türkay, M., 1986. Crustacea Decapoda Reptantia der Tiefsee des Roten Meeres. Senckenberg. marit., 18(3/6): 123-185.

Weber, F., 1795. Nomenclator entomologicus secundum entomologiam systematicam ill. Fabricii, adjectis speciebus * recens detectis et varietatibus: i-viii, 1-171 (apud CaroIum Ernestum Bohn, Chilonii [Kiel] et Hamburgi).

White, A., 1856. Some remarks on Crustacea of the genus Lithodes, with a brief description of a species apparently hitherto unrecorded. Proc. zool. Soc. Lond, 24: 132-135, pl. XLII.

Whiteaves, J.F., 1874. Report on further deep-sea dredging operations in the Gulf of St. Lawrence. Amer. J. Sci., (3) 7: 210-219.

Williams, A.B., 1965. Marine decapod crustaceans of the Carolinas. Fish. Bull, 65(1): i-xi, 1-298.

Williams, A.B., 1984. Shrimps, lobsters, and crabs of the Atlantic coast of the eastern United States, Maine to Florida: i-xvii, 1-550 (Smithsonian Institution Press, Washington, D.C.).

Williamson, D.I., 1992. Larvae and evolution. Toward a new zoology: 1-223 (Chapman \& Hall, New York).

Wolff, T., 1961a. A bathyal-abyssal hermit crab with a calcified asymmetrical abdomen. Nature, 190 (4779): 931-932.

Wolff, T., 1961b. Description of a remarkable deep-sea hermit crab with notes on the evolution of the Paguridae. Galathea Rep., 4: 11-32.

Wood-Mason, J., 1873. On Nephropsis Stewarti, a new genus and species of macrurous crustaceans, dredged in deep water off the eastern coast of the Andaman Islands. J. Asiatic Soc. Bengal, 42(2): 39-44.

Received: 22 March 1997 